\title{
A cidade enquanto artefato: o que evidenciam as décimas urbanas acerca da decadência na capitania de Goiás ${ }^{1}$
}

The city as an artifact: what Décimas Urbanas reveal about the decadence in the captaincy of Goiás

hitps://doi.org/10.1590/1982-0267202lv29d lel l

\author{
NÁDIA MENDES DE MOURA² \\ hitps://orcid.org/0000-0002-3326-370X \\ Instituto do Patrimônio Histórico e Artístico Nacional / UNESCO/ Brasília, DF, Brasil
}

RESUMO: $\bigcirc$ ouro foi o grande catalizador da povoação da Capitania de Goiás no século XVIII, ocupando parte dos sertões e criando uma rede de arraiais mineradores e estradas que conectavam a região central da colônia aos portos do litoral e à fronteira a oeste. Ao longo desse século, a busca pelo metal precioso redesenhou o vasto território, entrecortado por serras, planaltos e planícies, irrigado por rios, recoberto de matas e cerrado, terra originária de diversas etnias indígenas. Dos rios e das serras brotava o ouro, ao passo que surgiam novas povoações. Porém, o ouro não ficava nos arraiais - uma vez extraído, era despachado para longe, sem que thes dessem tempo para imprimir nos núcleos urbanos os sinais promissores da riqueza. A queda da produção aurífera, durante o século XIX, acarretou uma nova configuração econômica que teria acometido a Capitania com o fantasma da decadência. Neste artigo, pretendemos quebrar alguns paradigmas sobre esse tema e avaliar o peso da decadência em quatro núcleos urbanos da Capitania de Goiás: Vila Boa, Pilar, Meia Ponte e Natividade. Escolhidos para o estudo por possuírem a mesma gênese mineradora, esses núcleos apresentam trajetórias distintas e características próprias que evidenciam essa diversidade, rebatidas na sua materialidade e conformação social. Com a análise e espacialização dos dados da Décima Urbana, podemos visualizar no intraurbano os reflexos da crise do ouro, além de revelar aspectos importantes ligados à sociotopografia desses núcleos.

\begin{abstract}
1. Este artigo aborda alguns resultados obtidos a partir de uma pesquisa mais ampla desenvolvida como doutorado, cuja tese foi defendida em 2018 junto à Faculdade de Arquitetura e Urbanismo da Universidade de São Paulo (FAU USP), realizada com bolsa CAPES.

2. Arquiteta urbanista, doutora pela Faculdade de Arquitetura da Universidade de São Paulo (FAU-USP), área de concentração em História e Fundamentos da Arquitetura e do Urbanismo. Mestre em arquitetura e urbanismo, área de concentração em Conservação e Restauro pela Universidade Federal da Bahia e Especialista na mesma área pelo Cecre (Curso de Especialização em Conservação e Restauração de Monumentos e Conjuntos Históricos). Atualmente presta consultoria especializada ao Iphan (CGCO/Depam) por meio de contrato Prodoc Unesco. E-mail: <nadiammoura@yahoo.com.br>.
\end{abstract}


PALAVRAS-CHAVE: Arraiais mineradores. Decadência. Arqueologia da Paisagem. Décima Urbana.

ABSTRACT: In the 18th century, gold prospecting was the main factor for the increase of the population of Captaincy of Goiás. This activity occupied part of the highlands and created a network of mining hamlets and roads that connected the colony's central region from the coastal ports to the western border. Throughout this century, the search for precious metal redesigned this wide territory, intersected by mountains, plateaus and plains, irrigated by rivers, covered with forests and savannas, homeland for several indigenous groups. As gold emerged from rivers and mountains, new settlements were formed. The precious metal, however, didn't stay in those places - once extracted, it was immediately shipped, with no time to print its promising signs of wealth in urban centers. The fall in gold production, during the 19th century, lead to new economic configurations that supposedly affected the Captaincy with the specter of decadence. In this article, we wish to challenge some of the theme's paradigms as we assess the traces of decadence in four urban centers of the Captaincy of Goiás: Vila Boa, Pilar, Meia Ponte and Natividade. They were specifically chosen because they share the same origins in gold mining but also have gone different developments, which created their own characteristics and diversity, reflected in their materiality and social conformation. Through the analys and spatialization of the data extracted from the urban tax Décima Urbana, we may visualize some vestiges of the gold crisis and reveal important aspects related to the social topography of these places.

KEYWORDS: Mining hamlets. Decadence. Landscape Archeology. Décima Urbana. 
O ouro é uma tônica ao se tratar da Capitania de Goiás, uma vez que foi o responsável por catalisar o processo de ocupação do território. Com a queda da produção aurífera, ou seja, após um momento de riqueza e prosperidade, a historiografia tradicional atesta a "decadência" da capitania, discurso muito mencionado também na narrativa dos viajantes europeus do início do Oitocentos e nos relatos oficiais, seja na voz dos governadores da capitania le, logo em seguida, da província) ou nas Memórias elaboradas no começo do século, nas quais atestava-se o cenário crítico pelo qual passava a capitania. Por outro lado, o discurso oposto atesta a decadência apenas como uma construção historiográfica, já que ela nunca teria se manifestado na Capitania de Goiás. ${ }^{3}$

Sobre esse tema, todos os debates e discussões são válidos, e vários deles têm como ponto em comum a generalização. Longe de querer produzir mais uma pesquisa sobre a decadência da Capitania de Goiás, colocamos novamente a questão em discussão, a partir de outras condicionantes econômicas, políticas e sociais.

Partindo da leitura tradicional, que trata a decadência a partir do "ciclo do ouro", verificamos que o pico da extração aurífera ocorreu com a arrecadação do quinto, atingindo pouco mais de meia tonelada, em meados do século XVIII. ${ }^{4}$ Grande parte do ouro extraído era escoada pelas estradas por funcionários régios, negociantes e contrabandistas. Além disso, desde 1757 eram enviadas remessas anuais do metal para a Capitania de Mato Grosso, que aplicava os recursos para proteger as fronteiras da colônia portuguesa com a América Espanhola.

Dado que na Capitania de Goiás não houve acúmulo de capital, não vemos o luxo do que teria sido o esplendor da era do ouro, manifestado nas edificações ou nos bens móveis e integrados, salvo raras exceções. A pouca quantidade do metal que ficou na Capitania de Goiás servia como moeda de troca em forma de ouro em pó misturado com impurezas, ou ornamentava altares das igrejas e capelas de Vila Boa e dos arraiais mais prósperos. Para a grande parcela da população, sobravam dívidas. Situação não muito diferente da apontada por Souza a respeito do caso da Capitania de Minas Gerais, "a Coroa enriquecia, mas o mineiro ficava pobre". ${ }^{5}$ Imagine, então, o caso do mineiro da Capitania de Goiás, cuja extração de ouro foi bem inferior à da capitania vizinha. ${ }^{6}$

A extração de ouro nas Minas de Goiás e nas Minas do Tocantins foi iniciada na década de 1720, no território que viria a se tornar Capitania de Goiás em 1748. A partir do momento em que se iniciou a exploração aurífera, diferentes povos se dirigiram aos promissores arraiais, sobretudo "paulistas", "baianos", portugueses e 
africanos - a grande força motriz que movimentou a capitania. Vale lembrar que esse extenso território havia sido trilhado antes por sertanistas, religiosos e sesmeiros - sem mencionar as diversas etnias indígenas que lá habitavam, como os caiapó ao sul, os carajá e avá-canoeiro nas proximidades do rio Araguaia, os xavante entre os rios Araguaia e Tocantins, e os xerente a nordeste, dentre outras. A cartografia do Setecentos sinaliza a malha hidroviária, a rede de estradas e arraiais, e os grandes "vazios" no território, os sertões onde viviam as diversas nações indígenas (Figura 1).

Figura 1 - Mappa dos sertões que se comprehendem de Mar a Mar entre as capitanias de S. Paulo, Goyazes, Cuyabá, Mato-Grosso e Pará. Fonte: Fundação Biblioteca Nacional - Brasil.

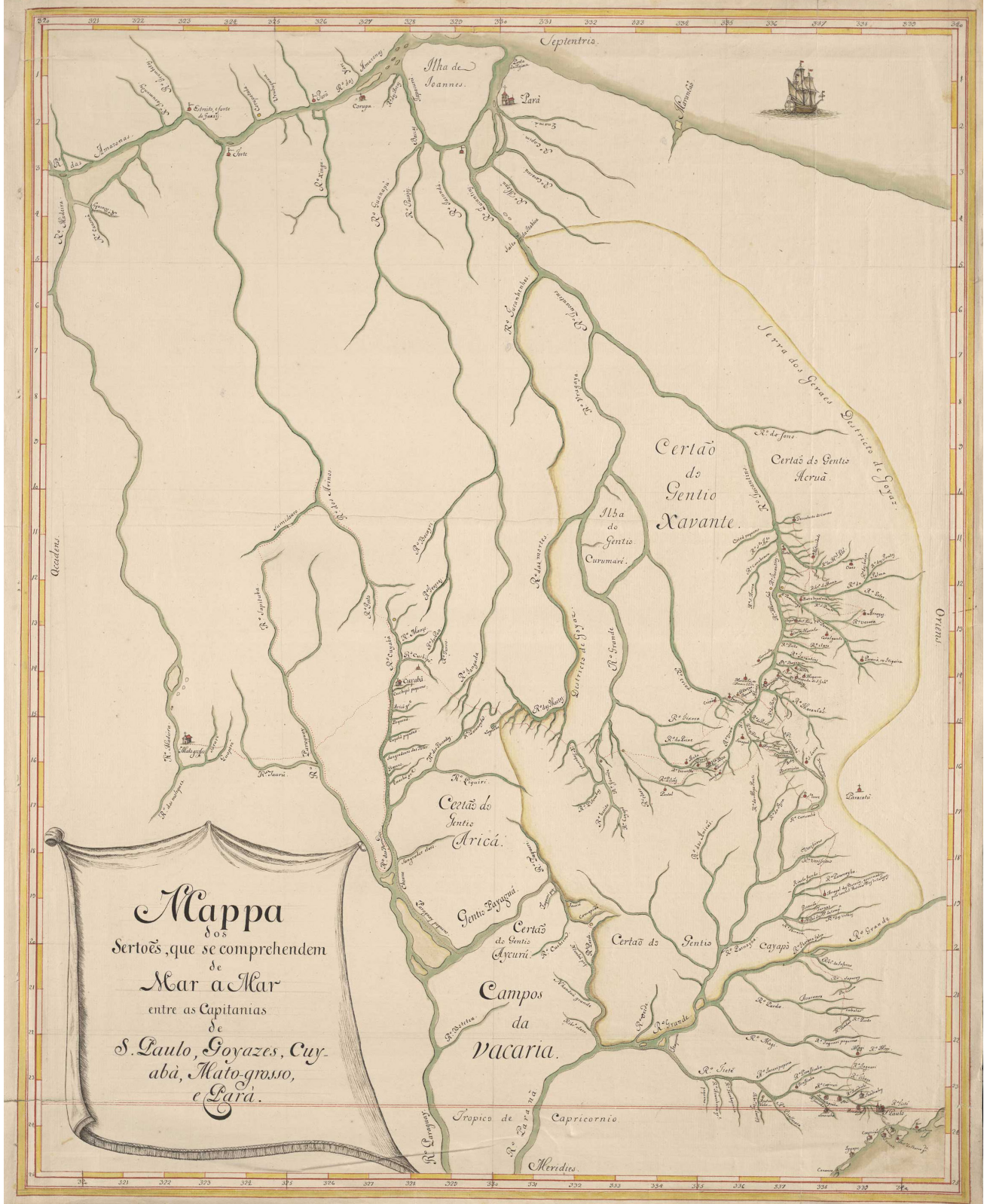


A Capitania de Goiás se caracterizava por seu extenso território ${ }^{7}$ e por sua posição central na colônia. Limitava-se ao norte com o Grão-Pará e Maranhão, a oeste com a Capitania de Mato Grosso, a sul com São Paulo e a leste com as capitanias de Minas Gerais e Pernambuco. Ao traçarmos a paisagem cultural regressiva da capitania, revela-se um quadro rico em diversidade natural e humana. Lá, encontramos três biomas diferentes: a Amazônia do noroeste, a Mata Atlântica do sudeste e o Cerrado, predominante. A apropriação das microzonas desse território aconteceu de forma diversa, estabelecendo interfaces macrorregionais diferentes. Logo, os modos de interação antrópica com o ambiente e os encontros culturais com os povos originários se deram de forma heterogênea. A partir daí, surgiram diversos tipos de ocupação e vocações econômicas, em decorrência das formas diferenciadas de apropriação. Isso se refletiu nos núcleos urbanos e em sua materialidade.

Diante desse quadro multifacetado, buscamos analisar o rebatimento da decadência - ou mesmo a sua ausência - nas cidades. Para este estudo, foram escolhidos quatro núcleos urbanos, cada um deles com características próprias, em uma tentativa de chegar o mais próximo possível do mosaico em que se constituía a Capitania de Goiás. Os núcleos escolhidos foram: Vila Boa, ${ }^{8}$ a capital da capitania; Meia Ponte, ${ }^{9}$ importante entreposto comercial, favorecido por sua localização no entroncamento de estradas; Pilar, um dos arraiais que mais se destacou na exploração aurífera no século XVIII; e Natividade, arraial das Minas do Tocantins que, além do ouro, também negociava gado. ${ }^{10}$

À exceção de Vila Boa, que já desempenhava um papel regional proeminente por ser vila, os três arraiais acumulavam as funções de sede de freguesia e de cabeça de julgado." Como ponto em comum, a gênese desses núcleos urbanos estava ligada à atividade mineradora. Ainda assim, cada um desses núcleos se desenvolveu de forma variada ao longo dos anos, sob condições diversas como localização, importância política e influência na economia local e regional. A partir daí, conseguimos mensurar o peso da decadência ocorrida com a crise da mineração em situações distintas, levando-se em conta também outras variáveis, para além da produção do ouro. José Jobson de Andrade Arruda ${ }^{12}$ percebe que o intervalo entre 1780 e 1830 correspondeu ao que chamou de "elo perdido da história econômica e social brasileira" justamente por conta de análises que desconsideram outras atividades econômicas, marcadas naquela época pela diversidade da produção agrícola e de subsistência. A economia nesse momento entre "a história vitoriosa do ouro e do café", a seu ver, apresentava um crescimento econômico lento e gradual, mais ou menos o que percebemos em alguns núcleos da Capitania de Goiás.

Assim, o recorte deste artigo compreende justamente esse período considerado "nebuloso", na transição do século XVIII para o XIX, momento em que
7. O território da Capitania de Goiás incorporava os atuais estados de Goiás, Tocantins e o Triângulo mineiro.

8. Vila Boa, no recorte temporal desta análise, teve seu título elevado para cidade em 1818, passando a ser reconhecida como Goiás. A cidade de Goiás perdeu o status de capital do estado de Goiás para Goiânia na década de 1930.

9. Atual cidade de Pirenópolis.

10. Os centros históricos das quatro cidades são tombados pelo Iphan.

11. "Julgado é uma povoação que não tem pelourinho $\mathrm{e}$ não goza dos privilégios de vila, mas é servida por justiça. Se por um lado as vilas precisavam da estrutura da Casa de Câmara e Cadeia, no caso dos julgados encontramos apenas a Cadeia, uma vez que não possuíam autonomia municipal." (Moura, 2018, p. 179).

12. Arruda (1997, p. 100). 
13. Neste artigo, preservamos a grafia original dos nomes de logradouros, proprietários e moradores dos imóveis, tal como constam na fonte primária. Para evidenciar tal aspecto, esses nomes aparecem em itálico ao longo do texto.

14. Tais como a localização do bem de raiz, seu proprietário (ou proprietária, considerando que a titularidade das mulheres diante dos imóveis urbanos na Capitania de Goiás igualava a dos homens) e identificação do/a morador/a, supondo que em alguns casos o imóvel estava alugado. Dependendo da cidade, os dados eram mais refinados, como no caso de Natividade, que apresentava o número de quartos dos imóveis.

15. O SIG equivale ao GIS - Geographic Information System.

16. As plantas atuais de Goiás (Vila Boa), Pirenópolis (Meia Ponte), Pilar e Natividade foram fornecidas pelo Iphan em arquivos de Auto Cad. Feitas as devidas adequações de como estariam esses sítios no início do século XIX, as bases cartográficas foram posteriormente trabalhadas em plataforma georreferenciada

17. Cf. Le Goff (1992).

18. Cf. Bueno (2005).

19. Cf. Borsoi (2013).

20. Cf. Kato (2011). a economia passava por transformações. Para esta análise, utilizamos a Décima Urbana como fonte principal. A Décima Urbana foi o primeiro imposto predial urbano estabelecido pela Coroa e pago à Fazenda Real. Foi promulgado por meio de alvará de 27 de junho de 1808 e implantado na Capitania de Goiás a partir de 1810. A "décima" correspondia ao percentual de aproximadamente 10\% sobre o rendimento de aluguel anual do imóvel e não se aplicava aos bens da Santa Casa de Misericórdia; aos imóveis em obras, arruinados ou desocupados; e aos imóveis cujos proprietários ou moradores vivessem em estado de pobreza.

A Décima Urbana ${ }^{13}$ apresenta o número de imóveis cadastrados e lista aqueles que se encontravam em uso, abandonados e até mesmo arruinados, revelando importantes índices de ocupação dos núcleos urbanos. Entre outros dados, ${ }^{14}$ a Décima também disponibiliza o valor do tributo cobrado por unidade, o que nos leva aos núcleos onde os imóveis estavam mais ou menos valorizados. Esses dados servem como índices palpáveis da situação econômica naquela época, permitindo alcançar diferentes matizes da crise, na escala do intraurbano, ao evidenciar aspectos ligados à ocupação das casas, seu estado de conservação e sua valorização. Com a análise desse material, aliado à bibliografia e ao cruzamento com outras fontes primárias, conseguimos esboçar o perfil desses núcleos urbanos.

Os dados das Décimas Urbanas foram transcritos e sistematizados em planilhas Excel, o que permitiu a migração das informações para o Quantum Gis, de modo a espacializar as informações em base georreferenciada. O SIG (Sistema de Informação Geográfica ${ }^{15}$ se revelou um grande aliado nessa análise, ao viabilizar a espacialização dos dados das Décimas Urbanas em bases cartográficas, ${ }^{16}$ permitindo a elaboração de mapas conjecturais temáticos e regressivos, reconstruindo territorialidades e reconstituindo espacialidades não mais existentes, mas significativas nesse recorte temporal. Mesmo resultando em uma cartografia hipotética, esses mapas nos permitem visualizar aspectos ocultos da materialidade urbana, evidenciando relações de sociabilidade entre os moradores ao revelar aspectos da sociotopografia urbana, ${ }^{17}$ com todas as nuances da paisagem social no âmbito da cidade.

Neste estudo, seguimos a metodologia adotada por Beatriz Bueno ${ }^{18}$ ao reconstituir a cidade de São Paulo por meio da Décima Urbana de 1809, para investigar as lógicas do mercado imobiliário então vigentes. Seguindo a mesma linha, também nos apoiamos no método de análise de Borsoi ${ }^{19} \mathrm{com}$ a reconstituição da Vila de Cunha por meio de censos e Décimas Urbanas e no estudo das Décimas Urbanas referentes às vilas de Paranaguá, Antonina e Curitiba no início do Oitocentos realizado por Kato. ${ }^{20}$

O processo de espacialização de dados não é nada fácil. Primeiro é preciso relacionar os nomes antigos com a nomenclatura atual dos logradouros, considerando 
que os nomes das ruas e dos largos foram alterados muitas vezes ao longo dos anos. Depois é preciso alcançar a lógica adotada pelo fiscal ao enumerar as edificações, normalmente separadas em lado direito e lado esquerdo (no caso de Natividade, o fiscal utilizou os pontos cardeais para essa tarefa). $\bigcirc$ sentido adotado pelo fiscal é outro desafio, uma vez que em alguns casos, no meio do caminho, ele muda a direção sem aviso prévio. Gauthiez e Zeller ${ }^{21}$ revelaram ter passado pelas mesmas dificuldades ao identificar o percurso estabelecido pelos fiscais da Vingtième ${ }^{22} \mathrm{em}$ Lyon, que também adotavam critérios subjetivos no seu percurso rua a rua.

Sobre essas questões, Mauricio de $\mathrm{Abreu}^{23}$ revela que o processo de reconstrução da cidade antiga é "muito mais pretencioso do que realizável". Mesmo assim, Abreu enfrentou as lacunas e reconstituiu o espaço do Rio de Janeiro no século XVII, abrindo importantes discussões sobre a transformação da cidade, servindo de baliza para pesquisadores de História social e urbana. Outro pesquisador que se debruçou no Rio de Janeiro colonial foi Nireu Cavalcanti, ${ }^{24}$ que revelou a complexa estrutura social da cidade no século XVIII e início do Oitocentos, desvelando aspectos culturais, políticos, econômicos e administrativos, rebatidos no espaço urbano.

Para a espacialização dos dados da Décima Urbana, a análise in loco é de fundamental importância, pois contribui na identificação dos logradouros e no reconhecimento da materialidade local. Ao caminhar e observar a cidade com calma, foi possível perceber as permanências e rupturas; por exemplo, em muitos casos a malha urbana se manteve, ao contrário do casario, que em alguns casos se modificou com o passar dos anos. Essas diversas camadas que compõem a paisagem urbana revelam sucessivos processos históricos, e seu entendimento é essencial para esse tipo de análise. A materialidade, muitas vezes interpretada como cenário, passa a ser lida enquanto documento histórico, fruto do processo de produção social da cidade.

A toponímia é um ponto muito importante no momento de relacionar os nomes dos logradouros. Até a República, os logradouros eram nomeados de acordo com seu "caráter", fazendo referência a certas atividades ou a natureza dos espaços. Seguindo a uma tradição medieval, a identificação dos logradouros nos sítios de matriz lusitana homenageava moradores ilustres ou ofícios predominantes e mercadorias ali comercializadas. ${ }^{25}$

Para reconstituir o espaço urbano de uma cidade juntamente com os dados da Décima Urbana, valemo-nos de fontes diversas: narrativas e descrições do período estudado; cartografia e iconografia de época; acervo cartorial e documentos oficiais; além da bibliografia produzida sobre a Capitania de Goiás e sobre as quatro cidades nos séculos XVIII e XIX. Os relatos dos viajantes europeus que passaram por essa capitania também foram importantes na análise das cidades
21. Gauthiez; Zeller (2004, p.102).

22. Imposto anual que correspondia a $1 / 20$ do valor do aluguel da propriedade urbana, equivalente a algo próximo das Décimas Urbanas. Gauthiez e Zeller (op. cit.) trabalharam com a coleta do imposto predial na cidade de Lyon nos séculos XVII e XVIII.

23. Abreu (2010, p. 303).

24. Cf. Cavalcanti (2004).

25. Cf. Andrade (2003). 
26. O conhecimento das dimensões e dos formatos originais dos terrenos seria indispensável em um estudo de morfologia urbana, que não é o foco desta pesquisa. Por essa razão, assumimos as imprecisões e o caráter hipotético dos mapas temáticos. Representamos em linha tracejada os terrenos que não dispomos de informações quanto à sua forma e localização exata.

27. Cf. Moura (2019).

28. Provisão (cópia) do rei... (1736). por seu status documental, uma vez que apresentaram relevantes aspectos econômicos e políticos, além dos sociais, ao tratarem da dinâmica cotidiana dos núcleos, revelando como se entrelaçavam as sociabilidades no Oitocentos. Com os filtros ativados em relação aos julgamentos de valor registrados nessas narrativas, nos aproximamos do modo de vida daqueles que lá viviam.

cruzamento de diversas fontes e a espacialização dos dados das Décimas Urbanas são essenciais para a reconstituição do espaço urbano, por fazer emergir questões ocultas, que seriam omitidas se ficassem limitadas a planilhas ou gráficos. A análise dos mapas temáticos oriundos da espacialização dos dados, por mais conjecturais que esses mapas sejam, viabiliza o olhar da vizinhança na escala do edifício, revelando personagens, grupos sociais e lideranças. Dessa forma, o estudo da cidade, para além das questões morfológicas do sítio urbano, ${ }^{26}$ abre novas frentes de pesquisa ao envolver questões sociais, privilegiando os atores locais, grandes transformadores do espaço urbano.

\section{VILA BOA}

arraial de Santana se desenvolveu em um vale cercado por montanhas, às margens do Rio Vermelho. Localizava-se a oeste de Meia Ponte, no caminho que conduzia à Cuiabá, nas Minas do Mato Grosso. Nos primórdios, o arraial apresentava duas centralidades principais: o largo da Matriz e o largo do Rosário, cujas igrejas atuavam como importantes agentes modeladores ${ }^{27}$ do núcleo urbano.

Por meio da Provisão emitida pelo rei D. João $V$ em 11 de fevereiro de 1736 ao Conde de Sarzedas, governador e capitão-general de São Paulo, foi ordenada a criação da vila. Esse documento não chegou a designar o lugar para sua criação, mas indicava que deveria ser em um sítio "que parecer mais saudavel e com provimento de boa agoa e lenha perto de algum arrayal que se ache já estabelecido para que os moradores dele possão com mais comodidade mudar a sua habitação para a villa". ${ }^{28}$ Alguns anos depois, mais precisamente em julho de 1739, 0 pelourinho foi instalado nas proximidades do Arraial de Santana, que passou a ser reconhecido por Vila Boa. Com o desmembramento da Capitania de São Paulo e a criação da Capitania de Goiás em 1748, Vila Boa passou a ser sede administrativa dessa capitania. A vila, que já contava com Casa de Câmara e Cadeia lainda provisória), Casa da Fundição e Quartel, passou a receber o aparato administrativo da nova capitania, principalmente a partir de 1749 com a chegada do governador. 
Em 1818, Vila Boa recebeu o título de cidade, passando a ser reconhecida como Goyaz. Por meio da Décima Urbana de 1818,29 analisamos a transição do núcleo de vila para cidade, alinhada ao momento em que recebeu a visita de SaintHilaire (1817), ${ }^{30}$ D'Alincourt (1818), ,31 Pohl (1818 e 1819) ${ }^{32}$ e, anos depois, Burchell (1828). ${ }^{33}$ Somados aos relatos dos viajantes que por lá circularam, realizamos o cotejamento das narrativas com os relatos do Diário do Barão de Mossâmedes de 1773 e com o conjunto de informações de 1783 provenientes da "Notícia Geral da Capitania de Goiás", além do material produzido pelo brigadeiro Cunha Mattos em 1824, ${ }^{34}$ bem como as Memórias Históricas de Silva e Souza de 1812 e 1832.35 Todas essas fontes, entrecruzadas à Décima Urbana da então Vila Boa de 1818,36 permitiram espacializá-la e analisar os dados de maneira georreferenciada.

As ruas, quase todas com calçamento em pedra, se ordenavam com certa regularidade. De maneira geral, Saint-Hilaire descreve as casas de Vila Boa como bem cuidadas, ${ }^{37}$ visão diferente de D'Alincourt que as considerou "medíocres". ${ }^{38}$ A expectativa em relação à Vila Boa sempre foi grande, por ser a sede administrativa de uma capitania exportadora de ouro. A decepção dos viajantes ao chegarem à vila nas primeiras décadas do Oitocentos era proporcional a essa expectativa, uma vez que esperavam encontrar um cenário mais próximo de Vila Rica (Ouro Preto), capital da Capitania de Minas Gerais. De acordo com Pohl, à primeira vista, Vila Boa oferecia um "belo quadro", entretanto, o "interior não corresponde a essa impressão, tendo aspecto pouco atraente". ${ }^{39}$ Saint-Hilaire, ${ }^{40}$ por sua vez, enaltece elementos da paisagem com seus morros cobertos por matas verdes, o céu "azul luminoso" e o conjunto urbano composto por "cerca de 900 casas", um número muito superior ao da Décima Urbana de 1818.

Vila Boa possuía 725 bens de raiz em 1818, o maior número de imóveis cadastrados nas Décimas Urbanas da Capitania de Goiás. A numeração dos imóveis segue em ordem crescente, e as casas construídas após o lançamento da primeira décima (1810) foram identificadas valendo-se da conjunção de números e letras, caso do imóvel 1A da Rua do Rozario ou da casa 150B da Rua da Abadia, dentre outros. ${ }^{41}$

O Lançamento da Décima Urbana de 1818 está dividido em dois volumes distintos: um referente ao bairro do Rozario e outro correspondente à margem sul do Rio Vermelho relativo à repartição de Santana. $\bigcirc$ arrolamento dos imóveis com sua respectiva numeração iniciou no livro do Rozario, mas é no caderno de Santana em que constam os membros da Junta da Décima Urbana, nomeados pelo juiz de fora Manoel lgnacio de Mello e Souza. ${ }^{42}$ Ao nos debruçarmos em cada um dos volumes, notamos que a grafia e a forma de apresentação dos dados são distintos. Isso pressupõe que não havia um padrão de lançamento das informações previamente estabelecido, e que os dados arrolados são heterogêneos. Mesmo
29. O Museu das Bandeiras (Muban) abriga as Décimas de Vila Boa/Goiás ininterruptamente de 1810 a 1822 . A Décima Urbana de 1818 , especializada neste artigo, encontra-se em perfeitas condições de análise.

30. Cf. Saint-Hilaire (1975).

31. Cf. D’Alincourt (1975).

32. Cf. Pohl (1976).

33. Cf. Ferrez (1981)

34. Cf. Mattos (1979).

35. Cf. Teles (1998).

36. Como Vila Boa foi reconhecida como cidade em setembro e o lançamento da Décima Urbana de 1818 ocorreu no primeiro semestre, quando tratarmos dos dados do tributo, vamos continuar nos referindo o núcleo como vila.

37. Saint-Hilaire (1975, p. 50).

38. D'Alincourt (1976, p. 94).

39. Pohl (1976, p. 140).

40. Saint-Hilaire (1975, p. 50).

41. O Decreto $\mathrm{n}^{\circ} 152$ de 16 de abril de 1842 esclarece o acréscimo da letra junto aos números dos imóveis: trata-se de construção de novos edifícios nas lacunas de uma malha urbana pré-estabelecida. Ou seja, a casa 1A foi construída ao lado do imóvel 1.

42. Fonte: Muban - Caixa 23, Pasta 1.1.4. "Lançamento da Décima e Receita”. 
43. Logradouro sem identificação, que abriga 12 imóveis, correspondente à continuação do Largo da Matriz.

44. A Rua do Jogo da Bolla foi mencionada duas vezes no lançamento da Décima Urbana de 1818. que o advogado Francisco Joze de Campos tenha sido nomeado como escrivão, tabelião e fiscal, acreditamos que pessoas diferentes tenham coletado as informações e sistematizado os dados em cada um dos cadernos.

Dos 725 imóveis, 279 estavam distribuídos na repartição do Rozario pelos seguintes logradouros: Rua do Rozario, Largo do Rozario, Rua da Cambauba, Rua de tras do Rozario, Rua do Ouvidor, Rua da Abadia, Campo da Forca, Rua do Carmo, Rua de Roza Gomes, Rua do Azougue e Rua de tras do Azougue; e o restante dos 446 imóveis estavam distribuídos do outro lado do Rio Vermelho, na repartição de Santana, pela Rua Direita, Becco da Lappa, Rua das Flores, Caes da Lappa, Largo de São Francisco de Paula, Rua das Almas e Marinho, Becco do Mingû, Largo da Matriz, [vazio], ${ }^{43}$ Rua de Manoel Gomes, Rua de Francisco Fernandes, Rua atras do Quartel, Rua do Horto, Becco de Joze de Mello, Rua da Fundição, Largo do Chafariz, Alto do Chafariz, Becco de Manoel Lourenço, Rio da Prata, Rua do Jogo de Bolla, Rua da Pedra, Rua do Jogo de Bolla $a^{44}$ e Becco de Joze Duarte (Figura 2).

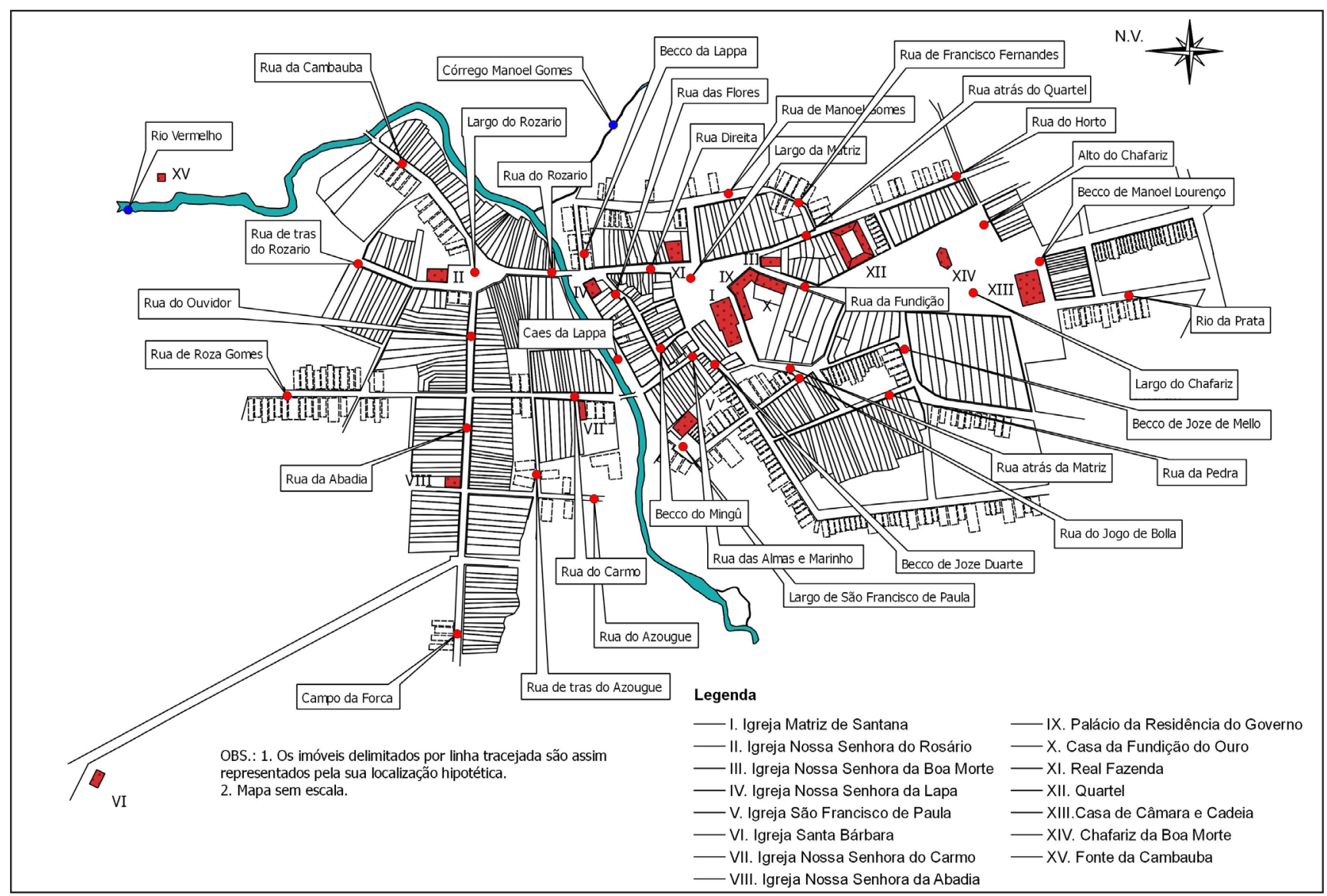

Figura 2 - Identificação dos Logradouros de Vila Boa em 1818 (sem escala). (Mapa hipotético elaborado com base no Lançamento da Décima e Receita de Vila Boa. Fonte: Muban - Caixa 23, Pasta 1.1.4.1 
Os equipamentos urbanos referenciavam a toponímia dos logradouros, tal como as ruas que faziam menção às igrejas ou caso das ruas do Campo da Forca, do Açougue público, do Horto, da Casa de Fundição, do Quartel e largo do Chafariz da Boa Morte (atualmente mais conhecido por Chafariz de Cauda). Da mesma forma, personagens importantes batizaram algumas ruas e becos, caso dos logradouros de Roza Gomes, Marinho, Francisco Fernandes, Joze de Mello, Manoel Lourenço e Joze Duarte. Ainda na identificação dos logradouros por meio da toponímia, nos deparamos com a Rua de Manoel Gomes, próxima ao córrego de mesmo nome, e a Rua do Ouvidor, onde estava localizado o imóvel que pertencia ao Senado da Câmara e que servia de residência ao "Doutor Dezembargador Ouvidor Geral e Corregedor da Comarca", cargo de Antonio Joze Alvares Marques da Costa e Silva em 1818 . Mesmo com as pistas fornecidas pela toponímia, não foi fácil relacionar os nomes antigos dos logradouros encontrados na Décima Urbana de 1818 com os nomes atuais. ${ }^{45}$

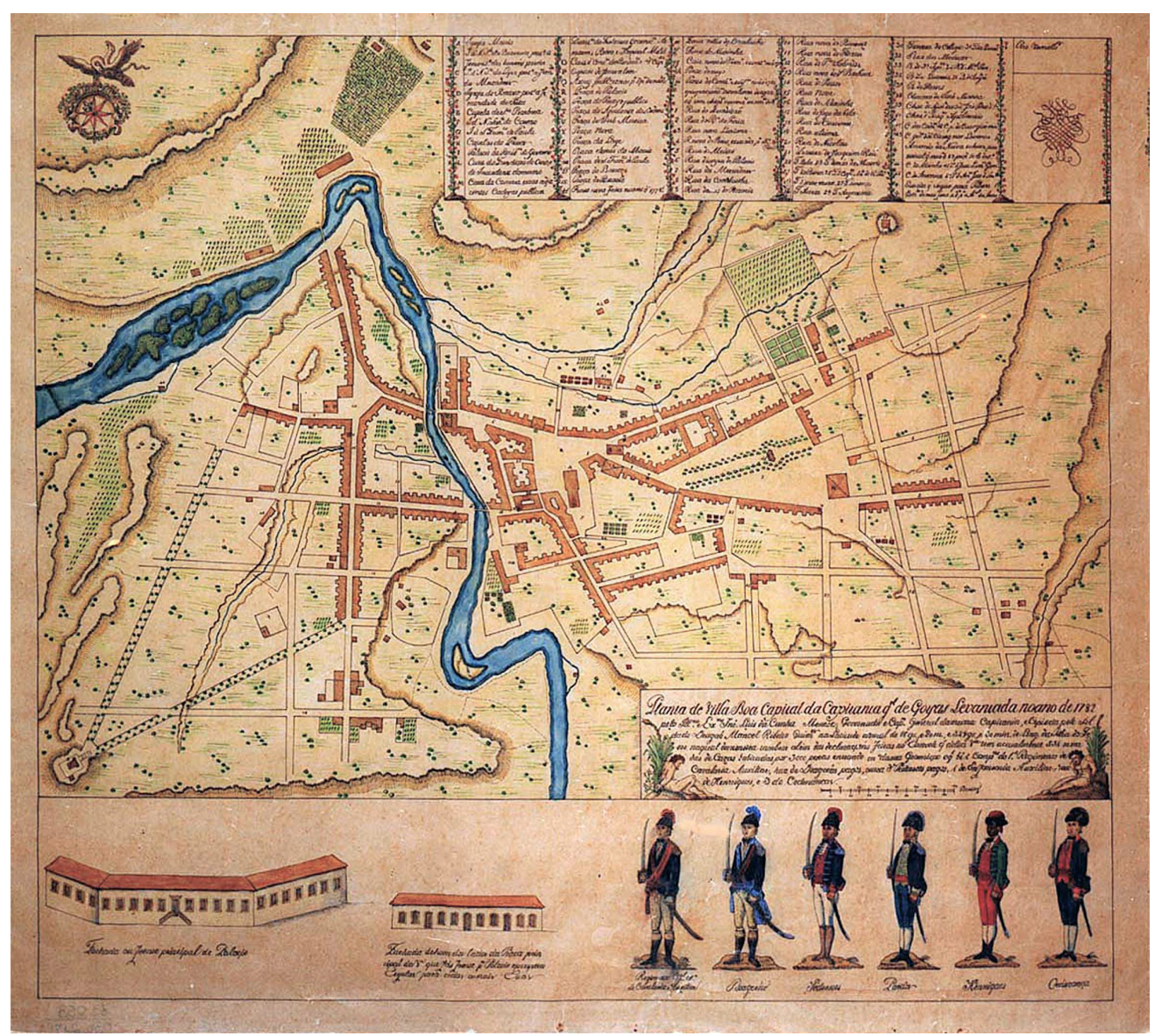

Figura 3 - Planta de Vila Boa Capital da Capitania Geral de Goyas levantada no ano de 1782. Fonte: Muban.
45. Nesse processo investigativo estendemos nossa pesquisa às obras de expoentes locais para contribuir nessa empreitada, como Cora Coralina (1987), Octo Marques (1977), Elder Rocha Lima (2008), Ofélia Sócrates Monteiro (1974), Nita (1981) e Regina Lacerda (1977). 
46. Essa planta é recorrentemente identificada em publicações e trabalhos acadêmicos como sendo de c. 1790 , entretanto foi elaborada entre 1765 e 1770 , em função das edificações representadas. Foram encontradas duas versões dessa planta com algumas diferenças, dado que uma é acervo do Museu Nacional de História Natural e da Ciência da Universidade de Lisboa (extinto Museu Bocage, Portugal) e a outra está na Casa da Ínsua, em Penalva do Castelo (Portugal).

47. Encontramos três cópias parecidas dessa planta em arquivos diferentes. A que utilizamos neste artigo encontra-se no Muban e as demais plantas foram localizadas no Arquivo Histórico Ultramarino e na Coleção de Obras Raras e Especiais da Biblioteca Mário de Andrade.

48. Elaborada por Henrique Morize, compõe o Relatório da "Commissão Exploradora do Planalto Central do Brazil" (Cruls, 1894).

49. De autoria desconhecida, o conjunto é composto pelo Prospecto de Villa Boa tomada da parte do Sul para o Norte no anno de 1751 (Figura 4); Prospecto de Villa Boa tomada da parte do Norte para o Sul no anno de 1751 (Figura 5) e Prospecto de Villa Boa tomada da parte do Esnoroeste para Les Sueste no anno de 1751. $\mathrm{O}$ acervo é da Casa da Ínsua (Portugal).

50. Comumente citado como Prospecto de Vila Boa, retrata a vila do adro da Igreja de Santa Bárbara. A Prespectiva é de autoria de Joaquim Cardoso Xavier, Alferes de Infantaria da Milícia, informação que se encontra na legenda da imagem. O original compõe a Coleção Pirajá da Silva da Seção de Obras Raras e Es-
Em relação aos dados da Décima Urbana, analisamos três mapas de Vila Boa-Goyaz: Planta da antiga Villa Boa dos Goyazes (c. 1772), ${ }^{46}$ Planta de Villa Boa Capital da Capitania Geral de Goyas (1782)47 (Figura 3), Planta da Cidade de Goyaz (1892). ${ }^{48}$ A documentação iconográfica também auxiliou bastante nesse processo, principalmente o conjunto de três vistas de Vila Boa de 1751, ${ }^{49}$ os desenhos de William Burchell de 1828, a Prespectiva de Villa Boa de Goyas de $1803^{50}$ e fotos antigas.

Tendo em vista a identificação dos logradouros, debruçamo-nos, sobretudo, na Planta de Vila Boa de 1782 e na Prespectiva de Villa Boa de Goyas de 1803. Ao confrontarmos os nomes das vias da Décima Urbana de 1818 com os nomes encontrados nessas fontes, constatamos que em raros casos os nomes se mantiveram.

Chegando à Vila Boa pela estrada que vinha de Meia Ponte, ou seja, reproduzindo o caminho das tropas, atravessamos o Rio Vermelho pela Ponte da Cambauba e adentramos a vila pela rua de mesmo nome. Seguindo adiante, deparamo-nos com o Largo do Rozario, "guarnecido de várias e elegantes casas" 51 no Oitocentos. O cenário pode ter se transformado na passagem do século XVIII para o XIX, uma vez que a estrutura dos lotes não só do Largo do Rozario, como da própria Rua do Rozario, se manteve com terrenos compridos compostos por testadas muito estreitas se comparados aos demais imóveis da vila, o que reforça a ideia da ocupação inicial ter sido de pretos e escravizados, devotos de Nossa Senhora do Rosário - em contraponto com o núcleo elitizado dos primeiros anos dos descobertos auríferos que ocupou a área do Largo da Matriz, onde foi instalada a capela de devoção à Santa Ana.

A transformação dos imóveis dessa área pode ser comprovada com a casa $n^{\circ} 6$ na Rua do Rozario, de propriedade do Reverendíssimo Governador (da Prelazia) Joze Vicente e Azevedo Noronha e Camara, ${ }^{52}$ que estava em obras. A autoridade, que também possuía os imóveis imediatamente vizinhos dos dois lados (casas números 5 e 7), muito provavelmente deve ter demolido uma casa menor que estava no terreno e optado por construir uma nova. O primeiro imóvel cadastrado na Décima Urbana de 1818, a casa $n^{\circ} 1 \mathrm{~A}$ situada na mesma rua, revela igualmente esse momento de remodelação daquela região, por se tratar de uma casa nova. Tanto a casa $n^{\circ} 1 \mathrm{~A}$ quanto a vizinha $n^{\circ} 1$ eram propriedades de Pedro Domingos Ferreira.

Em um núcleo urbano de casas predominantemente térreas, era no Largo do Rozario onde estavam dois dos sobrados da vila, ${ }^{53}$ pertencentes em 1818 a dois religiosos: o Padre Mestre Jozé Antonio de Souza e o Reverendo Antonio Ribeiro de Abreu, residentes nos imóveis $n^{\circ} 23$ e n ${ }^{\circ} 26$, respectivamente. Mesmo que fosse uma tipologia diferenciada, esses sobrados não figuravam entre os 
imóveis mais valorizados do núcleo (Tabela 1), uma vez que o rendimento anual do primeiro era de $36 \$ 000$ réis e do segundo de $28 \$ 800$ réis.

Tabela 1 - Imóveis mais valorizados em Vila Boa no ano de 1818

\begin{tabular}{|c|c|c|}
\hline Logradouro & Proprietário e morador & Rendimento anual \\
\hline Rua do Azougue, 267 & Senado da Camara da Villa & $86 \$ 400$ réis \\
\hline Largo do Rozario, 32 & Coronel Francisco Pereira Caldas & $72 \$ 000$ réis \\
\hline Rua das Almas e Marinho, 354 & $\begin{array}{l}\text { Capitão Mor Salvador Pedrozo de } \\
\text { Campos }\end{array}$ & $72 \$ 000$ réis \\
\hline Rua Direita, 288 & Dona Luiza Ferreira & $67 \$ 600$ réis \\
\hline Rua do Rozario, 12 & $\begin{array}{l}\text { (herança) Capitão Mor Antonio de S. } \\
\text { Telles e Menezes }\end{array}$ & $57 \$ 600$ réis \\
\hline Rua da Abadia, 138 & $\begin{array}{l}\text { Escrivão da Junta Raimundo Nonato } \\
\text { Hyacintho }\end{array}$ & $57 \$ 600$ réis \\
\hline Rua do Carmo, 231 & $\begin{array}{l}\text { Sargento Mor Jozé Ziferino M. de Men- } \\
\text { donça }\end{array}$ & $57 \$ 600$ réis \\
\hline $\begin{array}{l}\text { Largo de São Francisco de } \\
\text { Paula, } 347\end{array}$ & Dona Potenciana Ludovica de Carvalho & $57 \$ 600$ réis \\
\hline Rua do Jogo de Bolla, 583 & Coronel Francisco Xavier Leite & $57 \$ 600$ réis \\
\hline Rua das Flores, 306 & $\begin{array}{l}\text { Sargento Mor Antonio Joze Teles de } \\
\text { Avellar }\end{array}$ & $50 \$ 400$ réis \\
\hline $\begin{array}{l}\text { Largo de São Francisco de } \\
\text { Paula, } 341\end{array}$ & Capitão Joze Joaquim Pulquerio & $47 \$ 600$ réis \\
\hline
\end{tabular}

Tabela elaborada com base no Lançamento da Décima e Receita de Vila Boa. Fonte: Muban - Caixa 23, Pasta 1.1.4.

Conforme identificamos na Planta de Villa Boa, a Rua do Rozario em 1782 era conhecida como "Rua dos Mercadores", localizada nas proximidades do Rio Vermelho e da Igreja de Nossa Senhora da Lapa, templo extinto que estava na margem oposta do rio. Se levarmos em conta o nome da rua em 1782 e de uma das irmandades de devoção da Igreja da Lapa IIrmandade dos Mercadores), conjugado ao fato de que a estrada vinda de Meia Ponte com destino a Cuiabá passava por esse eixo composto pela Rua Cambauba - Largo do Rozario - Rua do Rozario - Ponte da Lapa - Rua Direita até chegar ao Largo da Matriz, e de lá para o Largo do Chafariz, verificamos uma forte tendência à atividade comercial ao longo dessa artéria, a principal da vila. Essa hipótese é reforçada ao verificarmos que o nome da Rua Direita em 1751 era "Rua direita do Negocio", conforme consta no Prospecto de Villa Boa tomada da parte do Sul para o Norte no anno de 1751 (Figura 4). peciais da Biblioteca Mário de Andrade.

51. Mattos (1979, p. 27).

52. De acordo com Azevedo (1985, p. 123), Joze Vicente teria tomado posse da Prelazia em janeiro de 1811. Ele era vizinho de seus irmãos na Rua do Rozario: morava ao lado de sua irmã, Dona Maria Vicencia da Expectação (casa $\mathrm{n}^{\circ} 8$ ), que era vizinha de seu outro irmão (casa n ${ }^{\circ}$ 9), o Coronel João Jozé de Azevedo Noronha e Camara (Livro de Notas $\mathrm{n}^{\circ}$ 55-1818-1820).

53. Dados da Décima Urbana de 1810, uma vez que a Décima de 1818 não apresenta a tipologia dos imóveis. No total, a Décima Urbana de 1810 aponta apenas três sobrados: dois no Largo do Rozario e um de propriedade do cirurgião-mor Lourenço Antonio da Neiva, na Rua da Cambauba. Ao que tudo indica ele já estava morto em 1818, portanto, os imóveis eram de seus herdeiros. Não sabemos precisar qual seria esse sobrado na Décima Urbana de 1818, uma vez que o cirurgião-mor (ou seus herdeiros) possuía outros imóveis nessa região, acesso de quem vinha de Meia Ponte. 
Figura 4 - Prospecto de Villa Boa tomada da parte do Sul para - Norte no anno de 1751. Fonte: Garcia (2002).

Figura 5 - Prospecto de Villa Boa tomada da parte do Norte para o Sul ; no anno de 1751, tomado do Largo do Rosário com destaque para a lgreja de Nossa Senhora da Lapa e Igreja Matriz. Fonte: Garcia (2002).
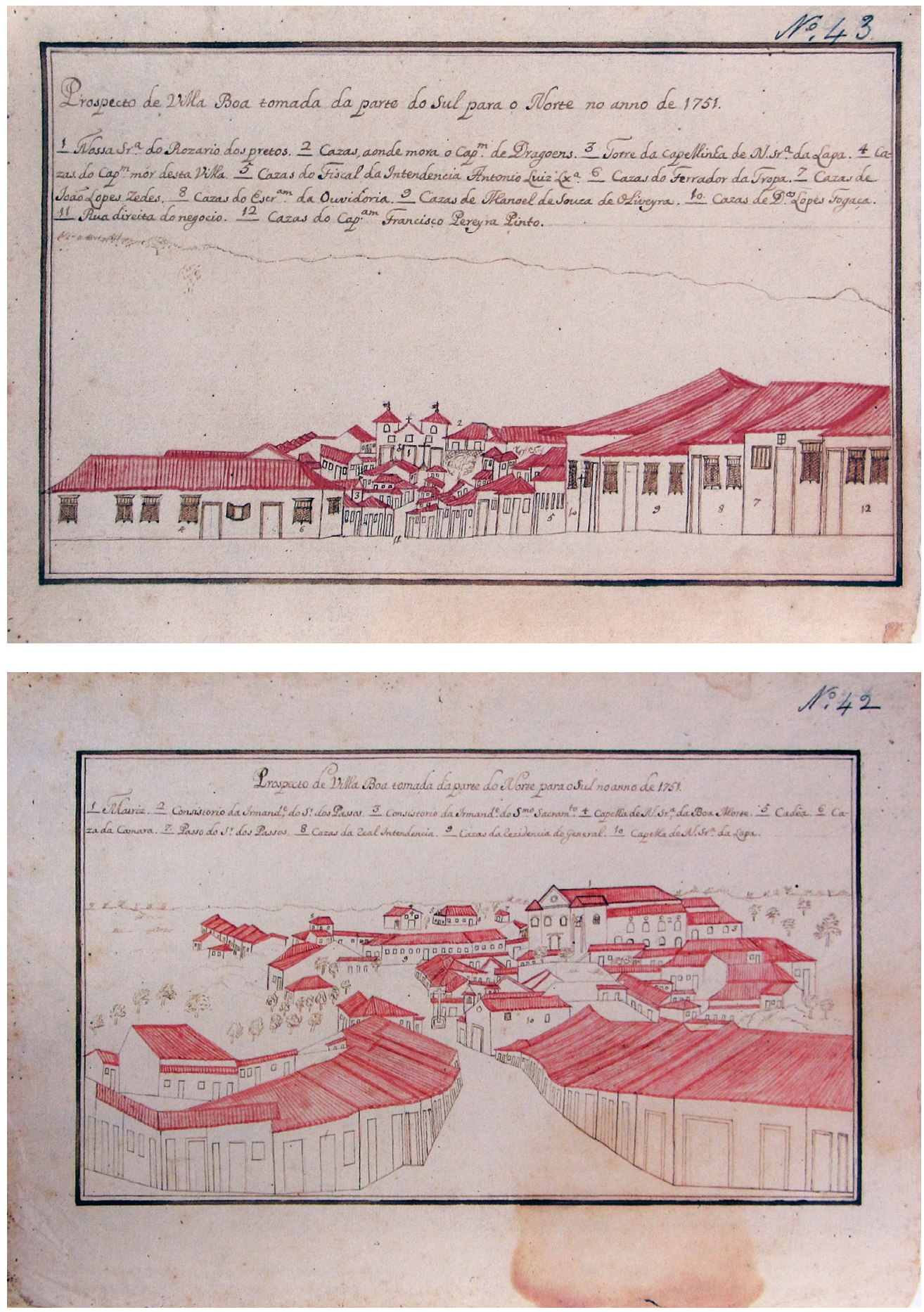

Analisando o Prospecto de 1751 (Figura 5) tomado a partir do Largo do Rozario, percebemos a incidência de muitos imóveis de vocação comercial no 
referido largo e na Rua do Rozario. Esses imóveis eram caracterizados por um casario com ritmada sequência de portas em detrimento de janelas, o que atesta a presença de "lojas". Mesmo que as informações contidas nas Décimas Urbanas não especifiquem o uso do bem, ao analisarmos a iconografia de época associada à toponímia, é possível vislumbrar algumas possibilidades.

Diante dessas evidências, podemos arriscar que alguns dos proprietários que possuíam mais de um imóvel localizado no Largo do Rozario e na Rua do Rozario, provavelmente os usariam para atividade comercial, optando por residir em outro endereço ou mesmo nos fundos da loja - caracterizando imóveis de uso misto. Outra questão importante diz respeito à finalidade dos imóveis: desse apanhado de 17 bens identificados nos dois logradouros, todos estavam na posse dos seus proprietários, ou seja, nenhum estava alugado. Ao analisarmos onde estavam os outros imóveis desses proprietários, verificamos que o raio de abrangência era pequeno, limitando-se às ruas de tras do Rozario, do Ouvidor e Direita - e ao próprio Largo do Rozario e a Rua do Rozario. Outro ponto de destaque é o valor elevado do rendimento anual dos imóveis - o que corresponde a edificações muito valorizadas, tendo em vista a testada estreita dos terrenos onde as casas estavam implantadas.

Para tentar entender a dinâmica dos usos dessas edificações, tomamos como exemplo o caso do Coronel Francisco Pereira Caldas, proprietário da casa n 32 no Largo Rozario - um dos imóveis mais bem avaliados de Vila Boa cujo rendimento anual era de $72 \$ 000$ réis. $\bigcirc$ coronel possuía outros imóveis, sendo um deles localizado na vizinha Rua Ouvidor n 103 e outro na Rua Direita n² 291, este último alugado para Manoel Joze Correa Viana. Diante desse quadro, podemos arriscar que a casa de esquina $\left(n^{\circ} 32\right)$ no Largo do Rozario teria um uso misto ou comercial - e a residência do coronel ficava logo em frente, próxima à quebra da esquina do largo com a Rua do Ouvidor (n 103).

Daquele lado do rio, ainda na repartição do Rozario, encontramos outros três imóveis elencados entre os mais valiosos de Vila Boa, tomando como base o rendimento anual da Décima Urbana de 1818. Situada no eixo comercial, às margens do Rio Vermelho, a casa $n^{\circ} 12$ na Rua do Rozario era de propriedade dos herdeiros do Capitão-Mor Antonio e Souza Telles e Menezes, tinha rendimento anual de $57 \$ 600$ réis $^{54}$ e foi alugada para o Capitão Jozé Joaquim Pulquerio, proprietário de um imóvel no Largo de São Francisco de Paula. Confiando na vocação da região do Rozario para a atividade comercial, podemos formular algumas hipóteses sobre o uso das casas: o imóvel alugado por Pulquerio na Rua do Rozario poderia estar voltado à atividade comercial, ao passo que a casa do Largo de São Francisco de Paula teria uso residencial. Ou o imóvel alugado da Rua do Rozario teria uso misto de loja e residência, enquanto a propriedade do
54. O imóvel em questão atualmente sedia o Museu Casa de Cora Coralina, onde a poetiza morou na juventude e nos seus últimos anos de vida. 
55. Antonio Joze Artiaga era proprietário de uma chácara nessa região, identificada na Planta de Vila Boa de 1782 (Figura 3). Com o crescimento urbano entre 1782 e 1818 , é possível que essa região, antes nos arrabaldes, tenha sido incorporada à área urbana.

56. As casas provavelmente compunham um único conjunto, embora o fiscal tenha apresentado informações mais aprofundadas apenas do imóvel $n^{\circ} 354$.

57. No terreno da casa foi construída no século XX uma sede do Banco do Brasil - um pastiche de arquitetura colonial de dois pavimentos.

58. Considerando como bens da Irmandade de Nossa Senhora da Lapa os imóveis cadastrados em nome de Nossa Senhora da Lapa, Capela da Irmandade da Lapa, Irmandade das Almas e Nossa Senhora da Lappa e Almas.

59. As irmandades das Almas, de Nossa Senhora do Rozario, de Nossa Senhora da Boa Morte, de São Francisco de Paula, de Santa Anna e de São Benedito também possuíam bens de raiz em Vila Boa.

60. Procuração bastante que fazem e assignão o Capitão Jozé Joaquim Pulquerio dos Santos e sua mulher Dona Maria Angelica, e Dona Anna Clara de Jezus aos nella nomeados como abaixo se declara. Fonte: Muban - Livro de Notas $n^{\circ}$ 68 "Juiz Municipal Joaquim Xavier dos Guimaraens Frances - 1835-1837 (folhas 121V, 122 e 122V). largo faria às vezes de casa de campo, uma vez que o bem pode ter conservado as características da chácara do falecido dono, o seu sogro Antonio Joze Artiaga. ${ }^{55}$

Saindo do imóvel alugado por Pulquerio e atravessando a Ponte do Meyo lou Ponte da Lapa), deparamo-nos com a lgreja de Nossa Senhora da Lapa. O caminho bifurcava na altura da igreja: à esquerda o Becco da Lappa, à direita a Rua das Flores e adiante a Rua Direita, que se dirigia ao Largo da Matriz. Conforme observamos no Prospecto de Villa Boa tomada da parte do Sul para o Norte no anno de 1751 (Figura 4), a Rua Direita apresentava características semelhantes às da Rua do Rozario, com maior incidência de casas com feições de imóveis comerciais ou de uso misto. A presença mais constante de portas em relação ao número de janelas atesta essa hipótese, ainda mais se confrontarmos aos imóveis ilustrados no Largo da Matriz.

Dentre os proprietários que possuíam mais de um imóvel na Rua Direita, destacamos o Capitão-Mor Salvador Pedrozo de Campos, dono da casa n 282, alugada para Salvador Cardozo de Almeida. $\bigcirc$ capitão-mor era proprietário de outros imóveis alugados em Vila Boa, situados na Rua da Cambauba (n 33) e no Largo do Chafariz $\left(n^{\circ}\right.$ 503). Seu grande tesouro não estava muito longe da Rua Direita, ele era proprietário de três imóveis vizinhos na Rua de Almas e Marinho, números 354, 355 e 356. ${ }^{56}$ Segundo consta na Décima Urbana de 1818, o capitão-mor tinha como residência a casa $n^{\circ} 354$ cuja lateral estava voltada para o cais do Rio Vermelho e figurava entre as mais caras de Vila Boa, com rendimento anual de $72 \$ 000$ réis. ${ }^{57}$

A irmandade de Nossa Senhora da Lapa também era proprietária ${ }^{58}$ de dois imóveis na Rua Direita, embora nenhum figurasse entre os mais valorizados. Os dois imóveis, vizinhos à Igreja da Lapa, estavam ocupados, sendo que o de ${ }^{\circ}$ 272 foi alugado para o Reverendo João Pereira Cardozo, e o de $n^{\circ} 273$ cedido para Bonifacio Furtado de Mendonça. Além desses imóveis, a irmandade possuía outros dois nas proximidades do eixo comercial Rozario - Rua Direita e outro um pouco mais afastado no Becco de Joze de Mello. O imóvel n 15, o mais valorizado da irmandade, localizado na Rua do Rozario, com rendimento anual de $36 \$ 000$ réis, estava alugado para o Reverendo Francisco Ignacio de Faria Vivas. Próximo dali, a casa n 36 da Rua da Cambauba estava alugada para Angela de Souza, e o imóvel no 458 do Becco de Joze de Mello, para João dos Santos. Tomando como base o rendimento anual dos imóveis, entre as irmandades, ${ }^{59}$ a Irmandade da Lapa e Almas era a que mais recebia de seus inquilinos.

Outro imóvel entre os mais valorizados da vila era a casa n ${ }^{\circ} 288$ da Rua Direita, de propriedade de Dona Luiza Ferreira, cujo rendimento anual era de $67 \$ 600$ réis. Dona Luiza era mãe do Capitão Joze Joaquim Pulquerio, que acabou herdando o referido imóvel: um sobrado "com cinco janelas de frente" e fundos para o Córrego Manoel Gomes. ${ }^{60}$ 
Seguindo pela Rua Direita, chegamos ao Largo da Matriz, praça onde se encontra a lgreja Matriz de Santana, o palácio do governo, ${ }^{61}$ o sobrado da Fazenda Real e a Igreja de Nossa Senhora da Boa Morte. Ao analisarmos o Prospecto de Villa Boa tomada da parte do Sul para o Norte no anno de 1751 (Figura 4), tendo como foco o Largo da Matriz, identificamos um conjunto com predominância de imóveis residenciais, caracterizados por casas com grande incidência de janelas (com rótulas, diga-se de passagem) em detrimento do número de portas. Em 1828, William Burchell fez desenhos do mesmo largo, onde o número de casas com feição residencial ainda representava a maioria, embora edificações com características de uso comercial também se fizessem presentes, sobretudo na lateral próxima à Rua Direita.

No largo observam-se moradores com distinções de "donas" e patentes militares. Embora o Largo da Matriz correspondesse a uma área nobre de Vila Boa, nenhum dos imóveis elencados no rol dos mais valorizados em 1818 estava ali localizado. Comparando a ocupação inicial setecentista dos largos da Matriz e do Rosário e a situação mapeada no início do século XIX, percebemos que a população mais abastada não é necessariamente aquela detentora de títulos e credenciais. A sociotopografia revela que essa elite é móvel e foi ocupando outros pontos da cidade, embora em Vila Boa tenha permanecido na zona central.

Às margens do Rio Vermelho estava localizado o imóvel mais valorizado de Vila Boa em 1818, cujo rendimento anual era de $86 \$ 400$ réis. De propriedade do Senado da Camara da Villa, 62 o açougue estava estabelecido na rua que levava seu nome. Foi edificado no governo de Luiz da Cunha Menezes e encontrase representado como "Açougue público e casas para depósito dos mantimentos" com a letra "Q" na Planta de Vila Boa de 1782 (Figura 3). Atualmente, esse equipamento público não existe mais. De acordo com o Mapa das Produçoens de Villa Bôa e os sete Julgados da Repartição do Sul na Capitania de Goyaz no anno de 1804, ${ }^{63}$ Vila Boa era o maior produtor bovino daquela região, com a produção de 1.135 reses - número pequeno se comparado aos dados da produção bovina dos julgados da Repartição do Norte. ${ }^{64}$

Deslocando um pouco do eixo central, no caminho para o arraial da Barra, estava localizado um dos imóveis mais valorizados de Vila Boa em 1818 , situado na Rua da Abadia $n^{\circ} 138$, cujo rendimento anual era de $57 \$ 000$ réis. Seu proprietário estava no rol dos membros da elite local, o Escrivão da Junta Raimundo Nonato Hyacintho. Funcionário da Real Fazenda e genro do Coronel Francisco Pereira Caldas, ${ }^{65}$ o escrivão criou uma relação de proximidade com Saint-Hilaire, recebendo-o para almoçar e jantar, sempre que o viajante não tinha "compromisso de fazer as refeições no palácio". 66 Hyacintho, nascido na Europa, era homem
61. Conhecido atualmente por Palácio Conde dos Arcos, em homenagem ao primeiro governador da Capitania de Goiás, D. Marcos de Noronha (o Conde dos Arcos), que governou a Capitania de 1749 até 1755 .

62. Como os imóveis da Câmara não eram tributados, não ficou muito clara a razão pela qual o açougue estaria listado na Décima Urbana, caso semelhante à casa do Ouvidor, que também pertencia ao Senado.

63. Cf. Livro de registro da correspondência oficial de d. Francisco de Assis Mascarenhas, capitão geral da capitania de Goiás, com a Corte, relativo ao governo da dita capitania (1804). Manuscritos - Cod. 09.04.002 e Cod. 09.04.003. Fundação Biblioteca Nacional (Rio de Janeiro).

64. Cf. Moura (2018).

65. O escrivão era casado com Dona Elena Pereira Hyacintho, filha do Coronel Francisco Pereira Caldas e de Dona Jozefa Ribeiro da Costa.

66. Saint-Hilaire (1975, p. 56). 
67. Saint-Hilaire (1975, p. 57).

68. Mattos, 1979 (p. 97).

69. Saint-Hilaire (1975, p. 57). viajado, e gostava de narrar suas "muitas aventuras". Sobre a casa deste, SaintHilaire não poupou elogios, classificando-a como extremamente limpa, "encantadora" e confortável tal como as "casas europeias". ${ }^{67}$ Cunha Mattos ${ }^{68}$ concorda ao classificála como uma das mais asseadas de Vila Boa. Um fato que Saint-Hilaire ${ }^{69}$ achou interessante é que todo o mobiliário e a prataria da casa foram fabricados em Vila Boa, inclusive uma liteira, que Hyacintho exibia com muito orgulho.

Os imóveis mais valorizados de Vila Boa estavam localizados na região central, com destaque para Rua do Rozario, Largo do Rozario e Rua do Ouvidor. Do outro lado do Rio Vermelho, encontramos uma maior concentração desses imóveis na Rua Direita, no Largo de São Francisco de Paula e no Largo da Matriz. Os imóveis menos valorizados foram identificados nas periferias, como o Becco de Manoel Lourenço, Rio da Prata, Rua do Jogo de Bolla, Campo da Forca e Rua de Roza Gomes. Esse cenário não se repetiu nos outros arraiais analisados neste artigo (Figura 6).

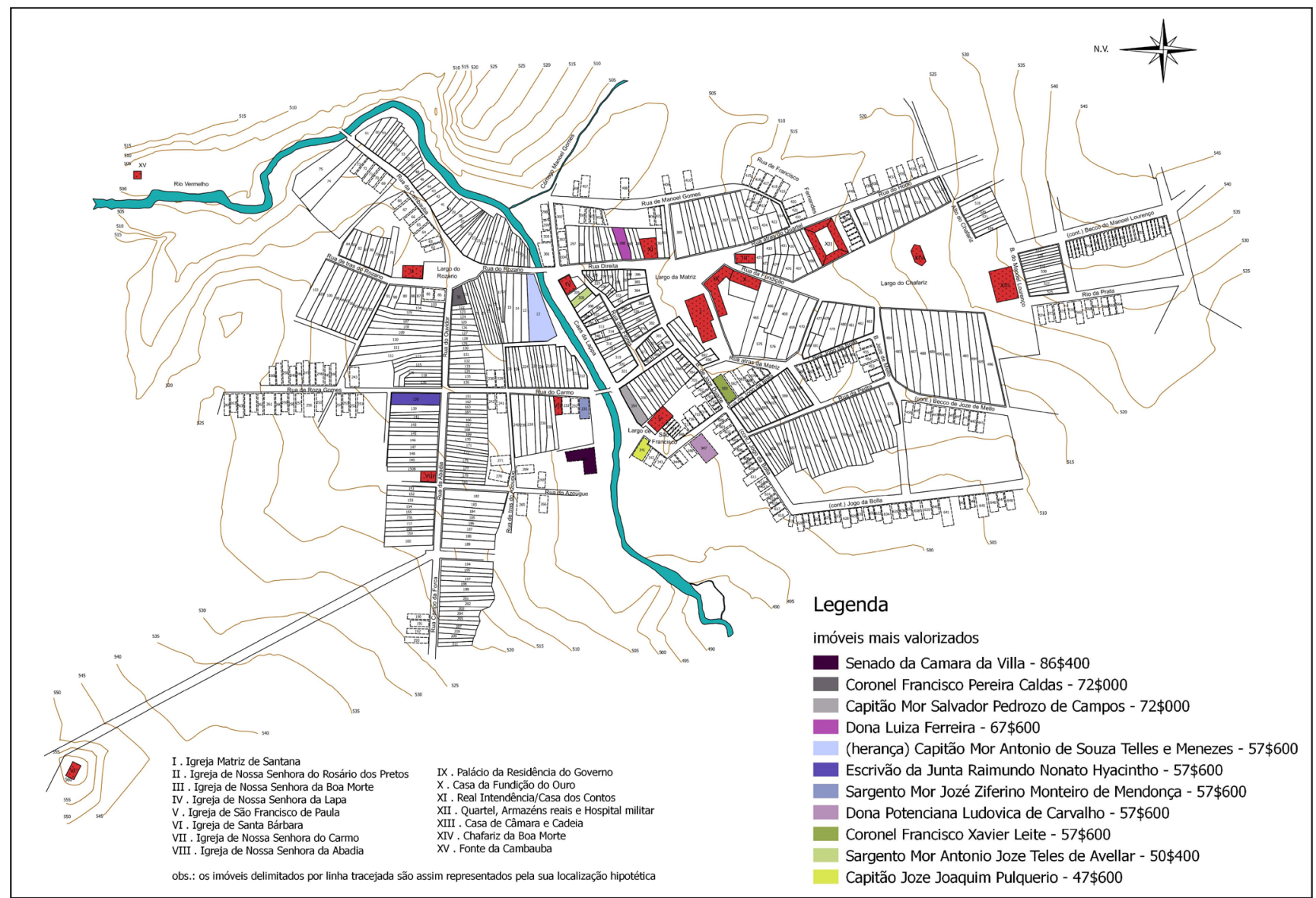

Figura 6 - Mapa de Vila Boa dos imóveis mais valorizados em 1818 (sem escala). (Mapa hipotético elaborado com base no Lançamento da Décima e Receita de Vila Boa. Fonte: Muban - Caixa 23, Pasta 1.1.4.1 
Em Vila Boa, de uma amostragem de 725 imóveis cadastrados em 1818, 482 casas estavam ocupadas, 12 não estavam sendo utilizadas e 231 não apresentavam informações quanto à sua ocupação (Figura 7). Desses 231 imóveis, 138 foram tributados em 1818, o que nos leva a crer que estavam sendo utilizados. Considerando este quadro e contabilizando todos os imóveis tributados, podemos afirmar que a taxa de ocupação dos imóveis de Vila Boa era de 85,5\%, para um total de 620 casas tributáveis e, portanto, sendo utilizadas. Da parcela dos 12 imóveis desocupados, 10 estavam arruinados, ${ }^{70} 1$ imóvel sem morador e 1 imóvel em construção - todos cadastrados na repartição do Rozario. Infelizmente, no caderno do distrito de Santana, não foram disponibilizadas informações tão refinadas, o que compromete a análise não só dessa repartição, mas de Vila Boa como um todo.

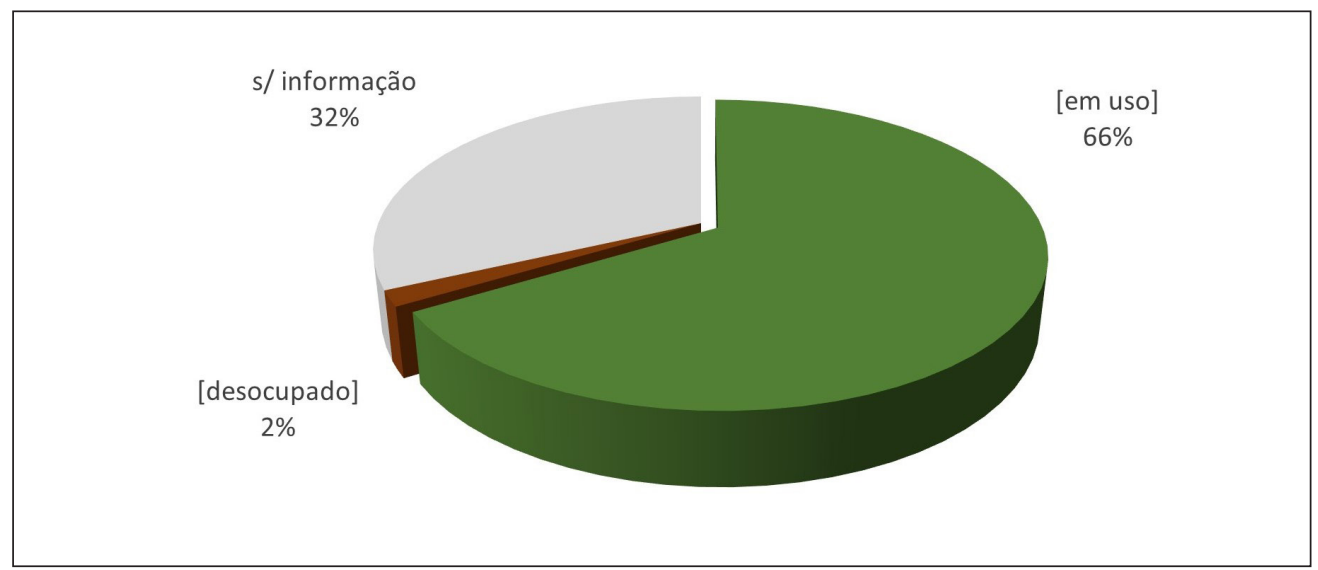

Figura 7 - Situação dos imóveis - Vila Boa 1818. Fonte: Caixa 20, Pasta 1.1.4. "Lançamento da Décima e Receita".

Tratando-se de um centro administrativo e sede do governo da capitania, os números se mostram razoáveis. Arriscamos afirmar que a taxa de ocupação seria ainda maior que $85 \%$ se os imóveis estivessem sido arrolados de maneira correta. De acordo com dados do Padre Silva e Souza, ${ }^{71}$ Vila Boa possuía 699 fogos em 1804. Em 1818, Pohl72 e D'Alincourt ${ }^{73}$ teriam chegado a um número próximo, equivalente a 700 casas. Cunha Mattos ${ }^{74}$ alegou a existência de 749 fogos em 1824, nos quais residiam 8.052 pessoas. De acordo com os dados expostos, verificamos que a transição de Vila Boa para cidade de Goiás sucedeu com um crescimento gradual e lento.
70. O fiscal não informa se os proprietários residiam nos imóveis arruinados. Para efeitos de sistematização dos dados, estamos considerando que as casas estavam desocupadas.

71. Teles (1998, p. 115).

72. Pohl (1976, p. 140).

73. D’Alincourt (1975, p. 94).

74. Mattos (1979, p. 27) 
75. Pinheiro; Coelho (2006, p. 85,87$)$.

76. Bertran (2010, p. 151)

77. Esse não é o mesmo Rio Vermelho da Cidade de Goiás.

78. Bertran (2010, p. 153 , 154).

79. Cf. Zanettini (2017).

80. Castelnau (2000, p. 268).

81. Teles (1998, p. 167).

82. Mattos (1979, p. 39, 97).
PILAR

Em 1773, em visita por Pilar, o então governador José de Almeida de Vasconcellos Soveral e Carvalho classificou o arraial como o "mais rico território desta Cappitania". ${ }^{75}$ Dez anos depois, o Juiz Ordinário relata ao governador Luís da Cunha Meneses em "Notícia Geral da Capitania de Goiás em 1783"76 as atividades mineradoras no Morro da Pedreira, "com bastante extensão, em o qual dizem haver ouro por todo ele". O relato continua, exaltando a existência de lavras e faisqueiras por todas as partes, inclusive no Rio Vermelho 77 e outros cursos d'água, mas reforça que "[...] lavra com regularidade de serviço com escravatura, só a chamada da Pedreira". O documento também lista a existência de lojas de secos e molhados e tavernas no arraial, além de engenhos de cana-de-açúcar e roças com monjolo compondo a paisagem circundante, ${ }^{78}$ o que comprova a existência de atividades que coexistiam simultaneamente com a mineração.

A zona de garimpo era bastante alargada, conforme é apresentado nos relatos do Setecentos e confirmado pelos sítios arqueológicos levantados pela Zanettini Arqueologia, ${ }^{79}$ que atestaram a abrangência dilatada das minas de Pilar. O arraial do Pilar se desenvolveu na encosta de uma serra em um sítio circundado por morros: a Serra do Moquem ao sul (região onde está localizado o Morro da Pedreira), a Serra da Boa Vista a leste e a Pendura a oeste. O Rio Vermelho, embora próximo do núcleo, não compunha a paisagem urbana, por estar localizado no sopé da Serra do Moquem. De acordo com Castelnau, as margens dos rios do Julgado de Pilar são "insalubres, por causa das inundações". ${ }^{80}$

Pilar estava conectada diretamente com Crixás, o arraial mais próximo. A uma distância de algumas léguas de viagem, o arraial se comunicava também com Traíras a nordeste; Vila Boa ao sul e Meia Ponte a sudeste. No século XIX, o contato também se dava por via fluvial, a partir do rio Crixás, afluente do rio Araguaia, e de lá seguia para Belém. ${ }^{81}$ No Setecentos, o arraial estabelecia comércio com a Praça da Bahia e com o porto do Rio de Janeiro, bem como as capitanias de Minas Gerais e São Paulo. No intraurbano, as ruas se apresentavam bem delineadas, sendo algumas delas calçadas em pedras, como as ruas da Cadeia, Direita e dos Paulistas.

As casas de Pilar são exemplares únicos, testemunhos da prosperidade vivida pelo arraial no auge da exploração aurífera. Foram descritas por Cunha Mattos como sendo "perfeitamente trabalhadas", "elegantes e bem acabadas". ${ }^{82}$ Em nenhum outro arraial - ou mesmo em Vila Boa - foram encontradas casas com tamanho primor e requinte, algumas das quais ainda conservadas (Figuras 13a e 13b). 
Esse cenário de prosperidade se altera com o declínio da produção aurífera. A manutenção das estradas já não era mais a mesma, conforme relata Cunha Mattos em 1824, ao apontar o arruinamento dos engenhos e de pontes sobre os rios que conduziam ao arraial. ${ }^{83}$ Pohl corrobora esse cenário, ao enfrentar dificuldades no acesso de Pilar em $1819^{84}$ a partir do caminho que seguia para Crixás. Ao deixar o arraial com destino a Meia Ponte, assim o viajante ${ }^{85}$ expôs a situação de completo abandono:

Depois de descermos a colina onde fica a povoação, entramos num capinzal de 4 e meio metros de altura, que se elevava muito acima de mim, apesar de estar eu a cavalo. [...] A travessia foi incômoda tanto para mim quanto para meus criados e até para os burros, por entre o ervaçal cortante do caminho. As espigas batiam em nossos rostos e, mesmo a cavalo, os resistentes colmos me fatigavam os pés. [...] $\bigcirc$ capinzal acompanhou-nos por quatro léguas inteiras.

Isso se reflete no decréscimo populacional pelo qual passou o arraial. Em 1783, Pilar possuía 522 fogos, conforme constava na "Notícia Geral da Capitania de Goiás". ${ }^{86}$ Em 1816 as Décimas Urbanas contabilizaram 284 casas, que viriam a se tornar 246 em 1824. De acordo com Cunha Mattos, o "arraial vai caminhando para uma completa aniquilação: as suas famílias mais nobres acham-se quase extintas; e grandes propriedades de casas estão completamente abandonadas" ${ }^{87}$

Para esta análise, optamos por trabalhar com as Décimas Urbanas de 1816 , pois apresentavam informações mais detalhadas que as demais décimas encontradas no Muban. ${ }^{88}$ Cotejamos os dados da Décima com as informações do Diário de Viagem do Barão de Mossâmedes de 1773," 89 da "Notícia Geral da Capitania de Goiás de 1783", 90 das Memórias Históricas de Silva e Souza (1 812 e 1832),91 bem como as considerações tecidas por Pohl ( 181 9) 192 e por Cunha Mattos (1 824).93

Ao contrário das Décimas Urbanas das outras cidades estudadas, não encontramos a folha inicial do Caderno de Lançamento que trata da "Junta da Décima Urbana" de Pilar. Dessa forma, não conseguimos levantar o nome do superintendente, nem os dos demais membros componentes da Junta. Apenas o escrivão Leandro Dias Barboza ${ }^{94}$ foi identificado na última folha do Caderno, encerrando o lançamento da Décima. O Caderno de Lançamento de 1816 não tinha suas folhas numeradas, tampouco apresentava rubrica nas páginas, procedimento padrão nos levantamentos das Décimas das outras localidades.

Foram cadastrados 284 imóveis distribuídos em 16 logradouros na Décima Urbana de Pilar de 1816 , porém duas ruas não apresentavam nome. $\bigcirc$ problema foi sanado com a identificação desses logradouros nas Décimas de 1821, razão
83. Mattos (2004, p. 130 , 133).

84. Pohl (1976, p. 188, 189). 85. Pohl (1976, p. 189, 190). 86. Bertran (2010, p. 154). 87. Mattos (1979, p. 39).

88. Encontramos no Muban somente as Décimas Urbanas de Pilar referentes ao intervalo 1810 a 1817 e a Décima de 1821. O Caderno de Lançamento da Décima Urbana de Pilar de 1816 encontrava-se em bom estado de conservação.

89. Cf. Pinheiro; Coelho (2006).

90. Cf. Bertran (2010).

91. Cf. Teles (1998).

92. Cf. Pohl (1976).

93. Cf. Mattos (1979, 2004).

94. Não foi encontrado nenhum imóvel em nome do escrivão, nem como proprietário, tampouco como inquilino. 
pela qual o nome aparece entre colchetes. Assim sendo, naquele ano foram listados imóveis no [Largo da Matriz], Rua da Olaria, Rua das Merces, Campo da Lan, Rua dos Paulistas, Rua Direita, Rua das Flores, Paneleira, [Vira Copos], Quatro Cantos, Rua da Cadea, Largo do Rozario, Contagem, Rua do Rozario, Campo das Cavalhadas e Jogo da Bola (Figura 8).

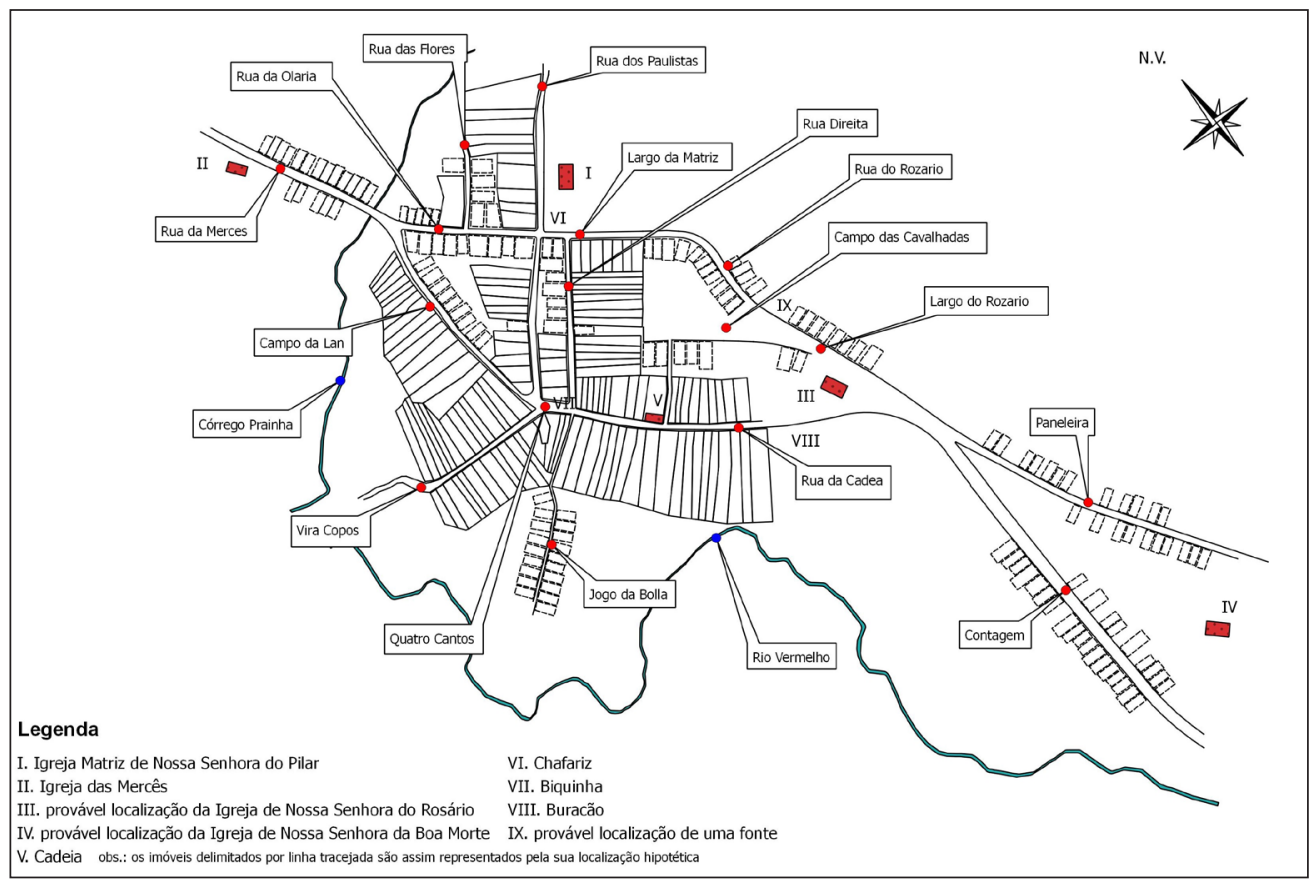

Figura 8 - Identificação dos Logradouros de Pilar em 1816 (sem escala). (Mapa hipotético elaborado com base no Lançamento da Décima e Receita de Pilar. Fonte: Muban - Caixa 20, Pasta 1. 1.4.)

A toponímia indicou a existência de certos equipamentos no arraial ou nos arredores, conforme aparece nos nomes de determinados logradouros, como Rua da Olaria, Rua da Cadea ou Contagem; da mesma forma nos acena o lugar das igrejas do arraial: o Largo da Matriz e Rua da Merces, e nos apresenta pistas da localização da extinta Igreja do Rosário dos Pretos, uma vez que dois logradouros fazem menção ao templo: Largo do Rozario e Rua do Rozario. Por outro lado, aspectos socioculturais e vocações locais transparecem pela toponímia, por meio de vias identificadas por Campo das Cavalhadas, Jogo da Bola, Vira Copos, Paneleira e Campo da Lan. Pessoas vindas de outras partes da colônia também foram homenageadas, caso da Rua dos Paulistas. Essas dicas nos guiaram na empreitada de localizar as vias na planta atual de Pilar, uma vez que vários logradouros tiveram seus nomes alterados ao longo dos anos.

Como não foram produzidas plantas do arraial de Pilar durante o período colonial, debruçamo-nos na planta da cidade de 1964 da tese "Notas sobre a 
arquitetura do século XVIII em Pilar de Goiás"95 (Figura 9) e nos levantamentos urbanos elaborados no âmbito do tombamento federal de Pilar, na década de 195096 (Figura 10).

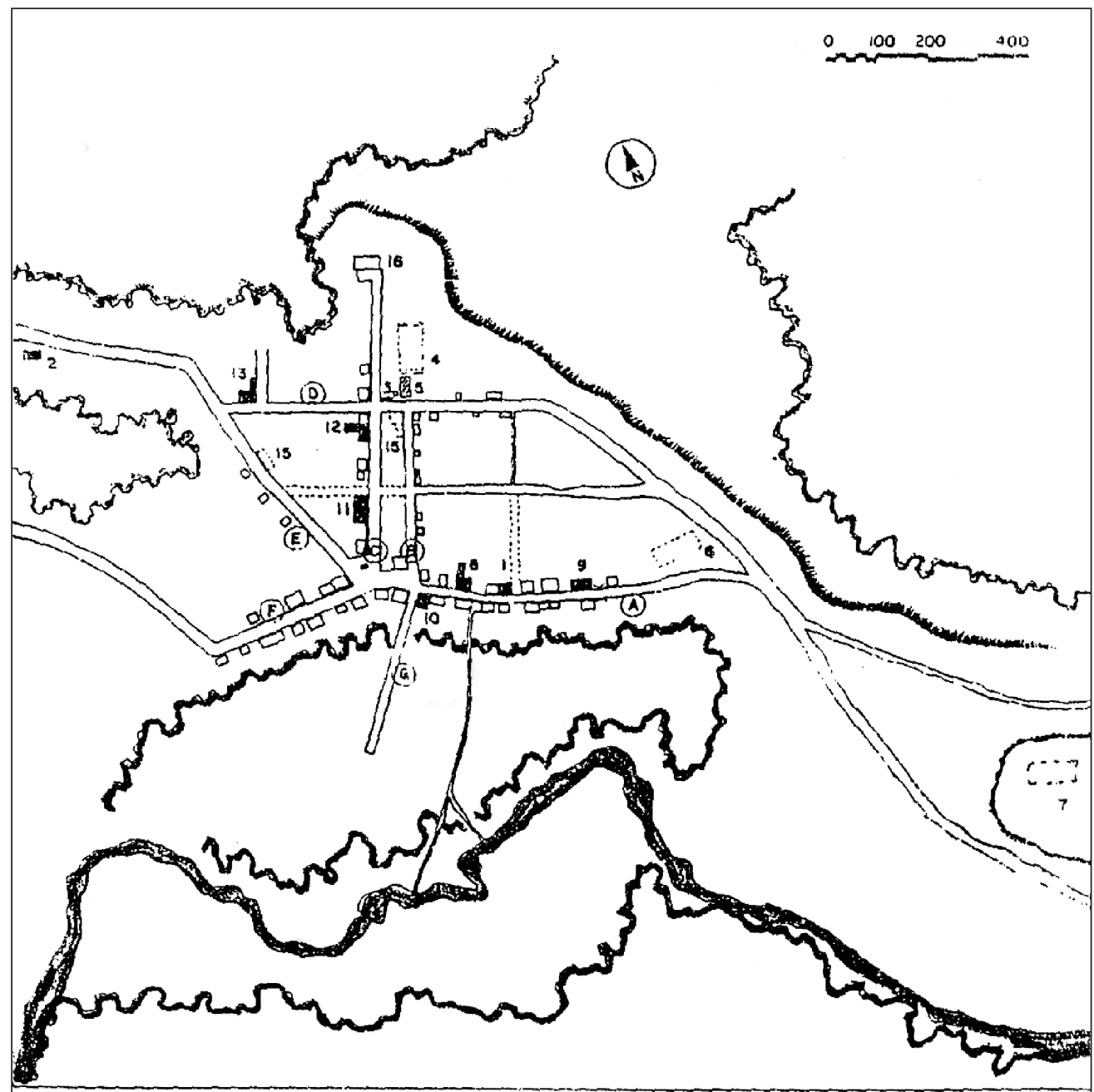

N.S. PILAR - PLANTA DA CIDADE 1964

Figura 9 - N. S. Pilar - Planta da Cidade 1964. Fonte: Dubugras (1965). Legenda conforme a fonte - 1. Casa de Câmara e Cadeia; 2. Ermida das Mercês; 3. Campanário; 4. Ruínas da Matriz; 5. Matriz Nova; 6. Ruínas da lgreja do Rosário; 7. Ruínas da lgreja da Ermida da Boa Morte; 8. Casa com rótulas e teto pintado; 9. Casa com Oratório; 10. Casa na esquina do Jogo da Bola; 1 1. Casa da Rua dos Paulistas I; 12. Casa da Rua dos Paulistas II; 13. Casa da Travessa da Matriz; 14. Para a Mina do Ogó; 15. Casas demolidas na década de 50; 16. Casa do Padre Braz de Pina. A. Rua da Cadeia; B. Rua Direita; C. Rua dos Paulistas; D. Travessa da Matriz; E. Travessa do Campo de Lã; F. Travessa Vira Copos; G. Beco do Jogo da Bola; H. Rio Vermelho. 


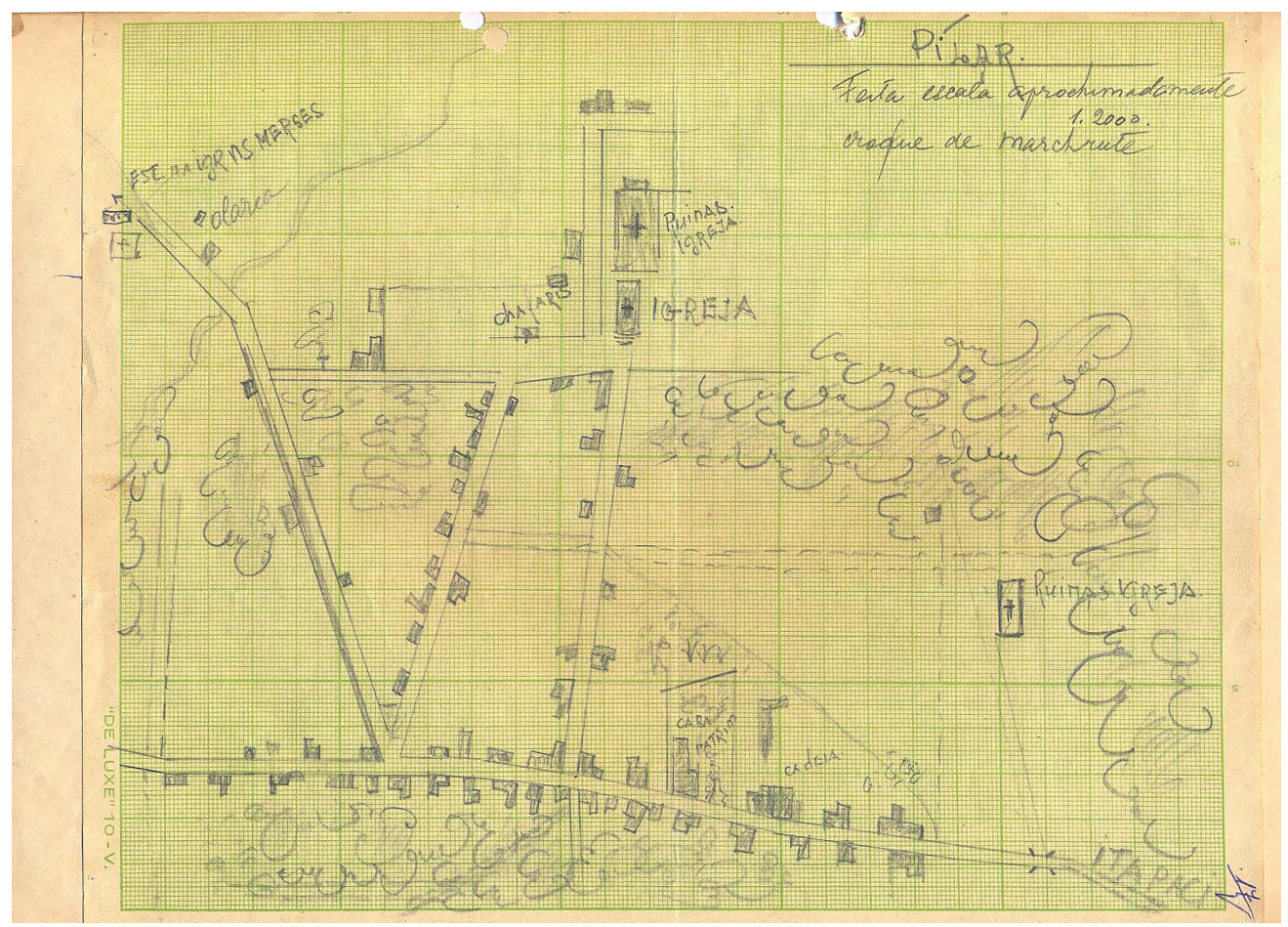

Figura 10 - Croqui de Campo de Pilar em 1952. Nota-se que a quadra triangular ainda apresentava sua feição original, ao passo que trechos da Avenida Central já se faziam presentes em linhas tracejadas. Fonte: Dphan (1952).

Importante salientar que não foram apenas os nomes das vias que se alteraram com o passar dos anos, o desenho urbano de Pilar também sofreu transformações no século XX. Entre as décadas de 1950 e 1960, uma nova via paralela à Rua da Cadeia cortou perpendicularmente a Praça das Cavalhadas e as ruas Direita e dos Paulistas, chegando até a Rua do Campo de Lã. Desse ponto, um novo trecho de rua foi aberto posteriormente, transpassando a quadra, seguindo paralela à Rua dos Paulistas, como se fosse uma continuação da Rua José Emídio. As modificações na morfologia urbana continuaram: a Praça das Mães era originalmente uma quadra completamente ocupada por casas, demolidas no início de 1950. Essa onda de demolições foi responsável por impulsionar o início do processo de tombamento de Pilar, visando proteger a cidade de novas intervenções que estavam descaracterizando seu conjunto arquitetônico e urbanístico.

Tendo como base uma planta digital atual da cidade, espacializamos os dados da Décima Urbana de 1816 trabalhando em plataforma georreferenciada. Dado que a cidade passou por vários processos de descaracterização urbanística e arquitetônica, e não foram produzidas plantas de Pilar nos séculos XVIII e XIX, ressaltamos que os mapas produzidos são hipotéticos e não refletem, 
necessariamente, o arraial do início do século XIX. Além da pesquisa documental e bibliográfica, a visita a campo fez parte do processo de identificação dos bens, assim como a consultoria dos arqueólogos que trabalharam no município de Pilar. ${ }^{97}$

Ao compararmos os dados das Décimas de 1816 e 1821 , percebemos que o número de casas diminuiu de 284 para 241, ou seja, 15\% em cinco anos, acenando para o fenômeno de retração do núcleo urbano. Os imóveis que desapareceram não estavam concentrados apenas na periferia, imóveis localizados na região central também foram abandonados no início do Oitocentos. $\bigcirc$ cenário ficou ainda pior ao analisarmos os dados referentes às Décimas de 1838 e 1839,98 que apresentaram o cadastro de apenas 213 casas, das quais 55 estavam arruinadas (Figura 11).

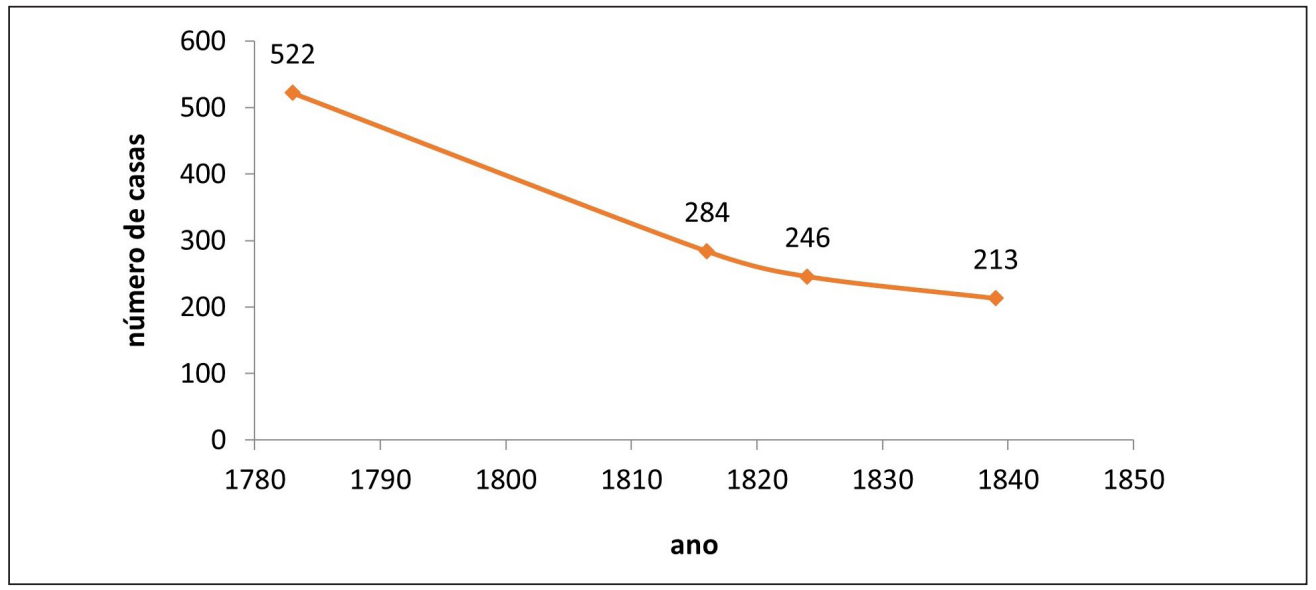

Figura 11 - Número de casas em Pilar por ano.

As informações constantes na Décima Urbana de 1816 oferecem um retrato da situação naquele ano: dos 284 imóveis, apenas 76 casas foram taxadas, o que corresponde a $27 \%$ do total. Dos $73 \%$ restantes, 86 imóveis não apresentaram informações sobre a ocupação e o estado de conservação do imóvel, 2 casas foram consideradas "inúteis", 4 "vagas" e 116 foram classificadas como "arruinadas", dando pistas sobre um arraial em processo de esvaziamento. Quase a metade dos imóveis de Pilar estavam desocupados, o que correspondia a $43 \%$ do total (Figura 12).

cenário do arraial, outrora próspero, era alarmante. Nenhum imóvel da rua do Jogo da Bolla foi tributado, ${ }^{99}$ situação que se repetia em outros logradouros, uma vez que não foram cobrados imposto de 208 casas em Pilar no ano de 1816. Eram imóveis ocupados por "viuvas pobres", "viuvas miseráveis", "cegos mendigos", "doentes", "indigentes", "mendigos", "miseráveis", "pobres", "velhos pobres", dentre outros. Como exemplos Clemencia Filicia (pobre), Aleixo (mendigo cego), Maria Cardoza (viuva miserável), Antonia de Souza (indigente), Marcelo de Miranda (mendigo) etc.
97. Arqueólogos Paulo Zanettini e Cláudio César de Souza e Silva, que trabalharam no âmbito do licenciamento ambiental da mina pertencente à Pilar de Goiás Desenvolvimento Mineral - Yamana Gold.

98. No Arquivo Histórico do Estado encontramos Décimas Urbanas de anos posteriores, como as de $1838 \mathrm{e}$ 1839. Fonte: AHE - Série Municípios - Caixa 01. Pilar de Goiás 1834 - 1850. Pasta 1838 "Coletoria - lançamentos das terças partes; miunças; engenhos; tavernas; décima urbana; café e fumo". Pasta 1839 "Coletoria - relatório dos impostos dos rendimentos provinciais; rendimentos das terças partes dos ofícios da Justiça; imposto da décima urbana".

99. Seja por isenção do imposto devido à pobreza do proprietário, pelo fato do imóvel estar arruinado, ou simplesmente por não apresentar dados referentes à coleta da décima. 
100. Como a Rua das Flores, Largo do Rozario, Contagem e Quatro Cantos.

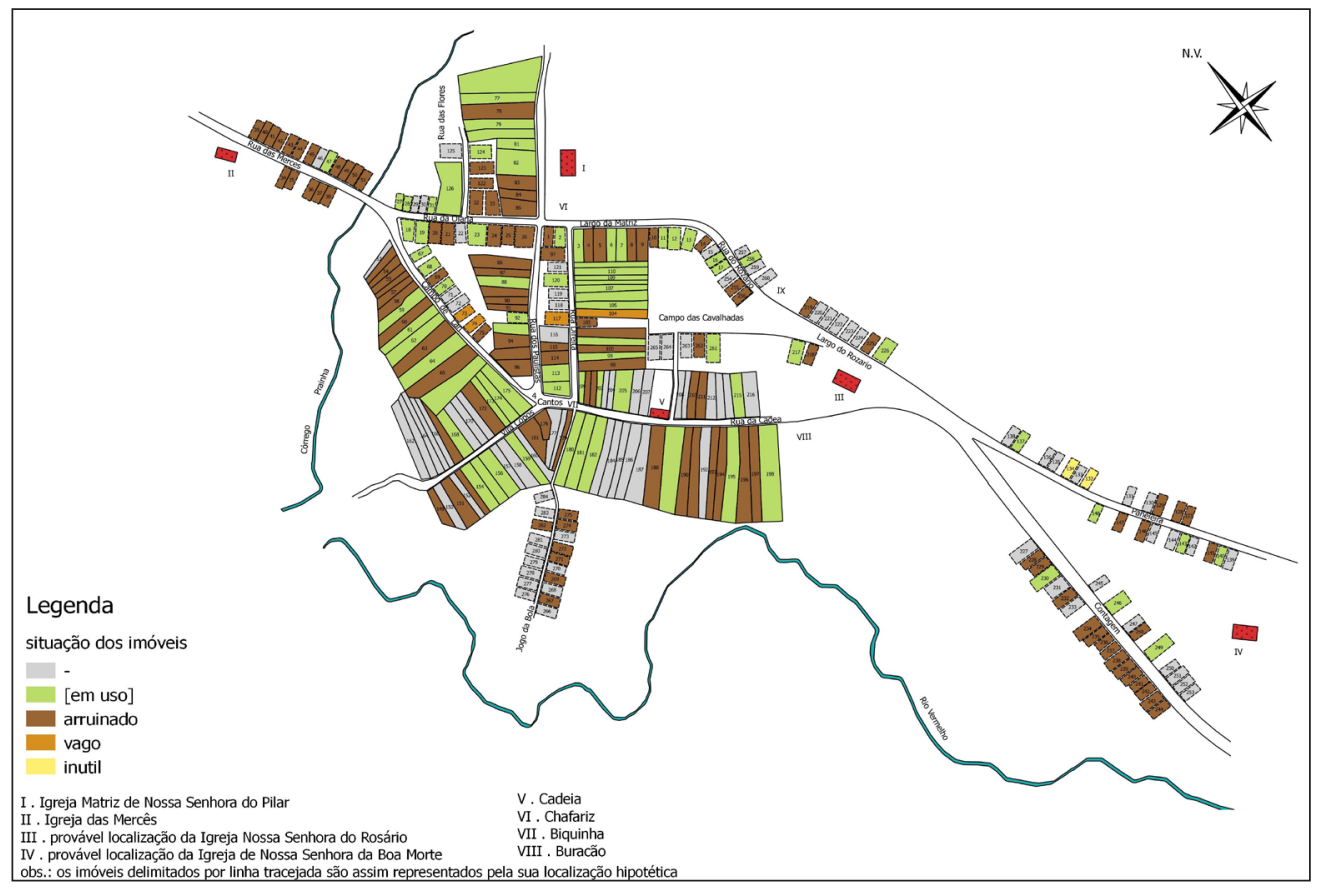

Figura 12 - Mapa de Pilar da situação dos imóveis em 1816 (sem escala). (Mapa hipotético elaborado com base no Lançamento da Décima e Receita de Pilar. Fonte: Muban - Caixa 20, Pasta 1.1.4.)

Na Rua das Merces, onde foram cadastrados 18 imóveis, residia somente uma pessoa, Maria Thereza de Jesus, na casa n 47. No Campo das Cavalhadas também só habitava uma pessoa, o Alferes Jozé Cipriano, no imóvel n² 261, assim como na Rua do Rozario, onde morava o Tenente Marinho Pereira na casa n⿳0 258. Outras ruas possuíam somente 2 ou 3 imóveis ocupados, ${ }^{100}$ reforçando a ideia de uma cidade em vias de desaparecer.

Alguns logradouros ainda mantinham certa dinâmica urbana, por apresentarem uma taxa de ocupação satisfatória para aquele cenário, caso do Largo da Matriz e das ruas Direita e da Cadea. Nestas duas últimas, estavam concentrados os imóveis mais valorizados de Pilar. Parte do que sobrou da elite de Pilar normalmente residia nessas ruas mais centrais, como na Rua dos Paulistas, composta por gente comum, mas também por "donas" e capitães. Uma classe identificada em Pilar, que não foi listada nos outros arraiais ou em Vila Boa, é a dos educadores, uma vez que encontramos um licenciado e um professor. $O$ professor João Soares Baptista morava na Rua Direita n 107, e o licenciado Joaquim Jozé Gomes Tição, na Rua da Cadea n 180. A casa do licenciado, a famosa "casa de enxaimel", era um dos imóveis mais valorizados do arraial, cujo rendimento anual era de $7 \$ 200$ réis (Figura 13a). 


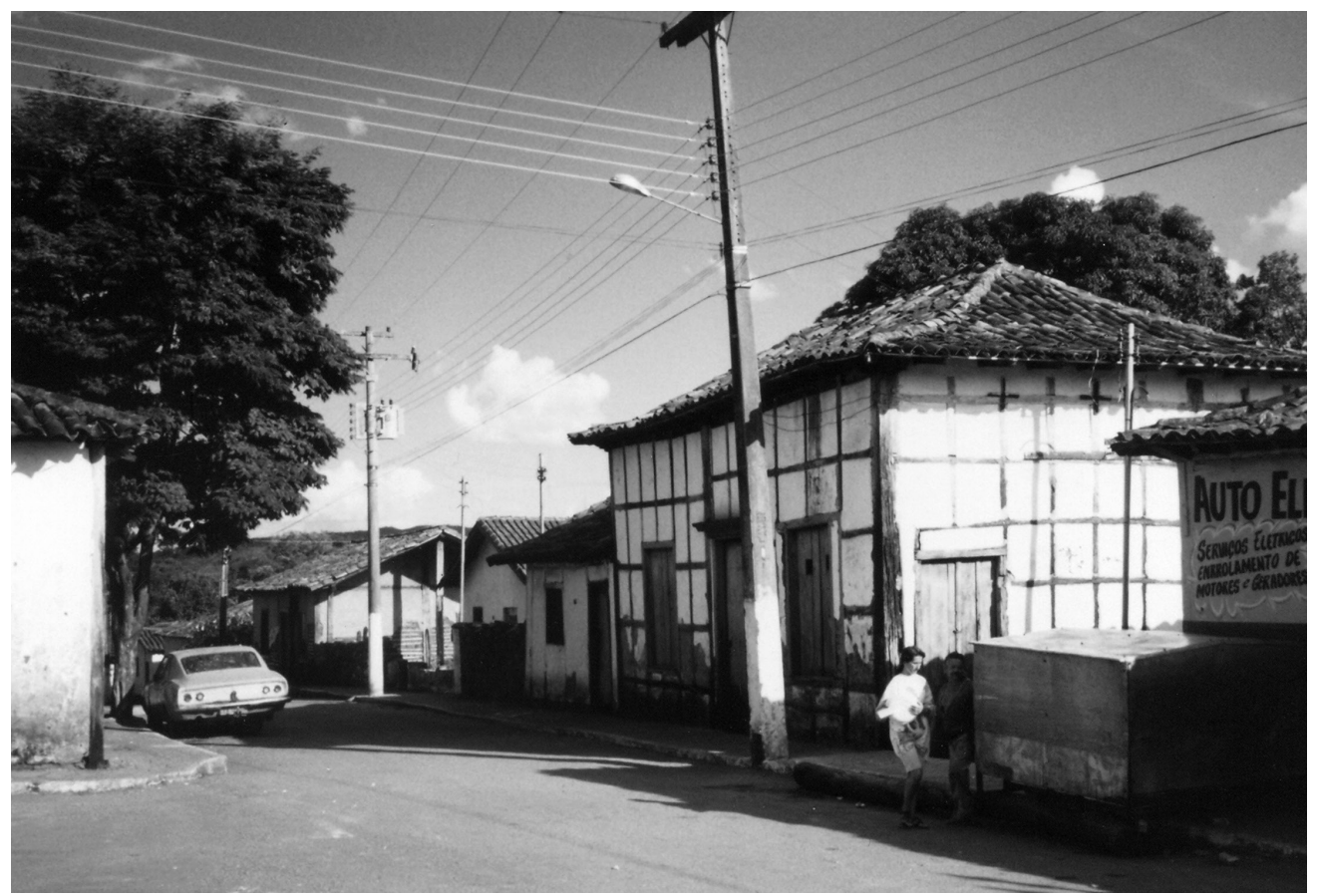

Figura 13a-Casa de enxaimel. Fonte: Iphan GO.

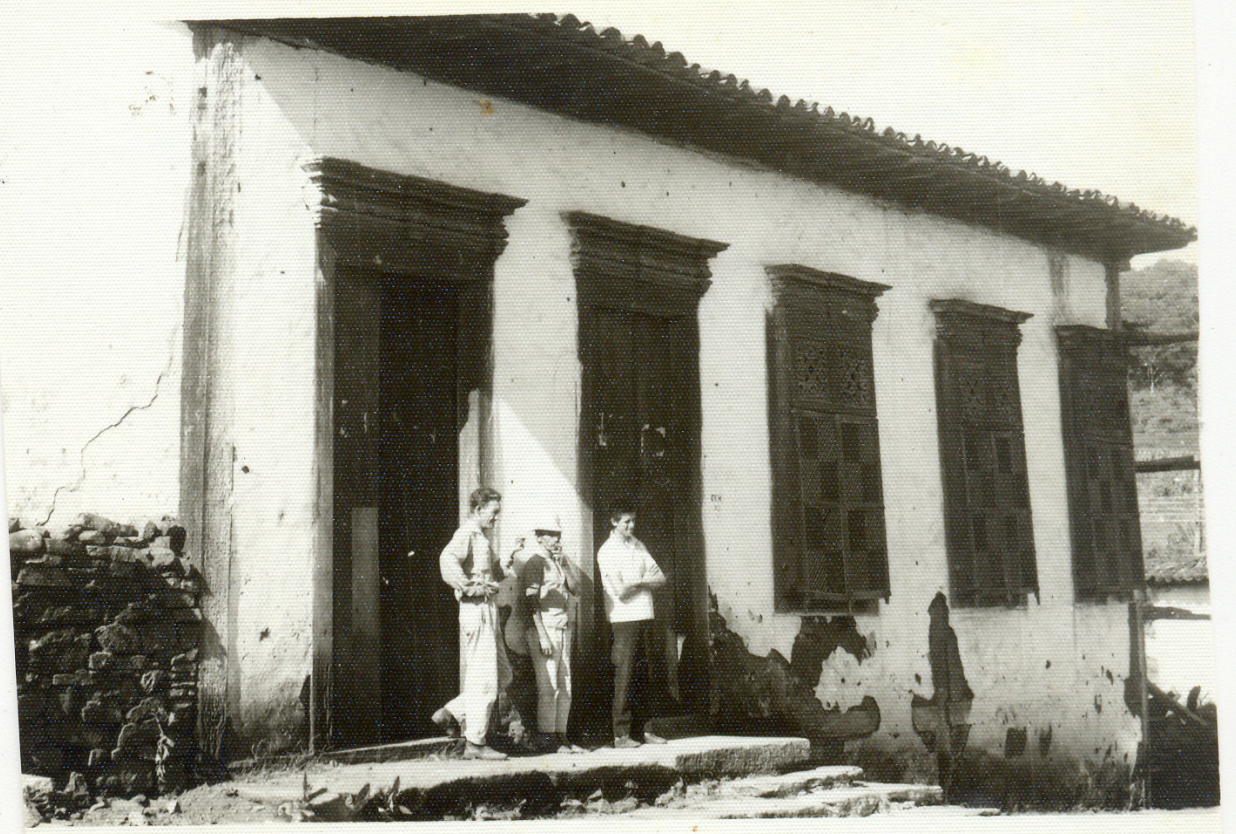

Figura 13b-Casa setecentista. Fonte: Iphan GO.

Outro imóvel que resistiu e se manteve de pé é a "casa setecentista", também localizada na Rua da Cadea (Figura 13b). A casa n² 205 se caracteriza 
101. Na Décima Urbana de 1821, o imóvel foi classificado com o $\mathrm{n}^{\circ} 126$. Isso pode ter ocorrido em função da readequação da contagem dos imóveis, considerando que várias casas desabaram entre 1816 e 1821. por suas imensas rótulas com treliças de madeira coroadas por bandeiras fixas ricamente talhadas, compondo um delicado rendilhado. Trata-se de um dos imóveis mais bem valorizados do núcleo, com rendimento anual de $7 \$ 200$ réis. A casa era o único imóvel do Capitão Comandante Jozé Pereira de Oliveira e Lago e, dois anos antes, tinha um rendimento anual de $20 \$ 000$ réis (Tabela 2 ).

Cotejando os dados com os valores registrados na Décima Urbana de 1814 , identificamos que os imóveis mais valorizados também se encontravam em outros logradouros centrais, como no Largo da Matriz, Largo do Rozario, Rua dos Paulistas e Vira Copos, com valores muito superiores a $7 \$ 200$ réis. Ou seja, em poucos anos, os imóveis tiveram uma desvalorização bastante acentuada, o que reforça o caráter de crise em que vivia Pilar no início do Oitocentos.

Tabela 2 - Imóveis mais valorizados em Pilar no ano de 1816 (quadro comparativo com 1814)

\begin{tabular}{|l|l|l|l|}
\hline Logradouro & Proprietário e morador & Rend. Anual 1816 & Rend. Anual 1814 \\
\hline Rua da Cadea, 205 & $\begin{array}{l}\text { Capitão Comandante Jozé } \\
\text { Pereira de Oliveira e Lago }\end{array}$ & $7 \$ 200$ réis & $20 \$ 000$ réis \\
\hline Rua Direita, 112 & $\begin{array}{l}\text { Capitão Manoel Antonio de } \\
\text { Siqueira }\end{array}$ & $7 \$ 200$ réis & $16 \$ 000$ réis \\
\hline Rua da Cadea, 198 & $\begin{array}{l}\text { Capitão Vicente Jozé Ferreira } \\
\text { de Azevedo }\end{array}$ & $7 \$ 200$ réis & $16 \$ 000$ réis \\
\hline Rua da Cadea, 180 & $\begin{array}{l}\text { Licenciado Joaquim Jozé Gomes } \\
\text { Tição }\end{array}$ & $7 \$ 200$ réis & $7 \$ 200$ réis \\
\hline Rua Direita, 120 & $\begin{array}{l}\text { Reverendo Vigário Thomaz } \\
\text { Pinto Adorno França }\end{array}$ & $7 \$ 200$ réis & $7 \$ 200$ réis \\
\hline
\end{tabular}

Tabela elaborada com base nos Lançamentos da Décima e Receita de Pilar. Fonte: Muban - Caixa 20, Pasta 1.1.4.

Um caso interessante diz respeito ao imóvel no 154 de Joanna da Silva, na Vira Copos. Em 1814, a casa era o imóvel mais valorizado de Pilar, cujo rendimento anual chegava a $25 \$ 000$ réis, cifra similar aos imóveis mais bem cotados em Meia Ponte em 1819 e em Natividade em 1817. Em 1816, esse imóvel foi avaliado com apenas $14 \%$ do valor atribuído em 1814 , ou seja, seu rendimento anual foi avaliado em $3 \$ 600$. Curiosamente, em 1821 o rendimento anual da casa passou para $7 \$ 200$ réis, ${ }^{101}$ demonstrando oscilação no mercado imobiliário de Pilar.

Os imóveis mais valorizados do arraial (Figura 14) estavam nas mãos de uma elite local, parte dela ainda ligada a figurões do passado. Fortes evidências nos levam a crer que os dois proprietários citados acima são parentes próximos de mineradores e proprietários rurais de 1783, apontados na "Notícia Geral da Capitania de 
Goiás". ${ }^{102}$ Ao que tudo indica, o Licenciado Joaquim Jozé Gomes Tição poderia ser filho do português Licenciado Francisco Gomes Tição com Dona Eufrasia Maria Xavier Pissaro, filha de paulistas. ${ }^{103}$ Francisco Tição era um dos proprietários da lavra no Ribeirão Fundão, sócio do Capitão Francisco Pereira do Lago e outros parceiros não identificados, responsáveis por 95 escravos. Por outro lado, o Capitão Comandante Jozé Pereira de Oliveira e Lago, proprietário da "casa setecentista" poderia apresentar parentesco com o sócio de Tição. Outro provável parente do minerador seria o Tenente Jozé Francisco Pereira do Lago, contratador da Contagem da Senhora da Piedade entre 1795 e 1797, e residente no imóvel n 99 da Rua Direita.

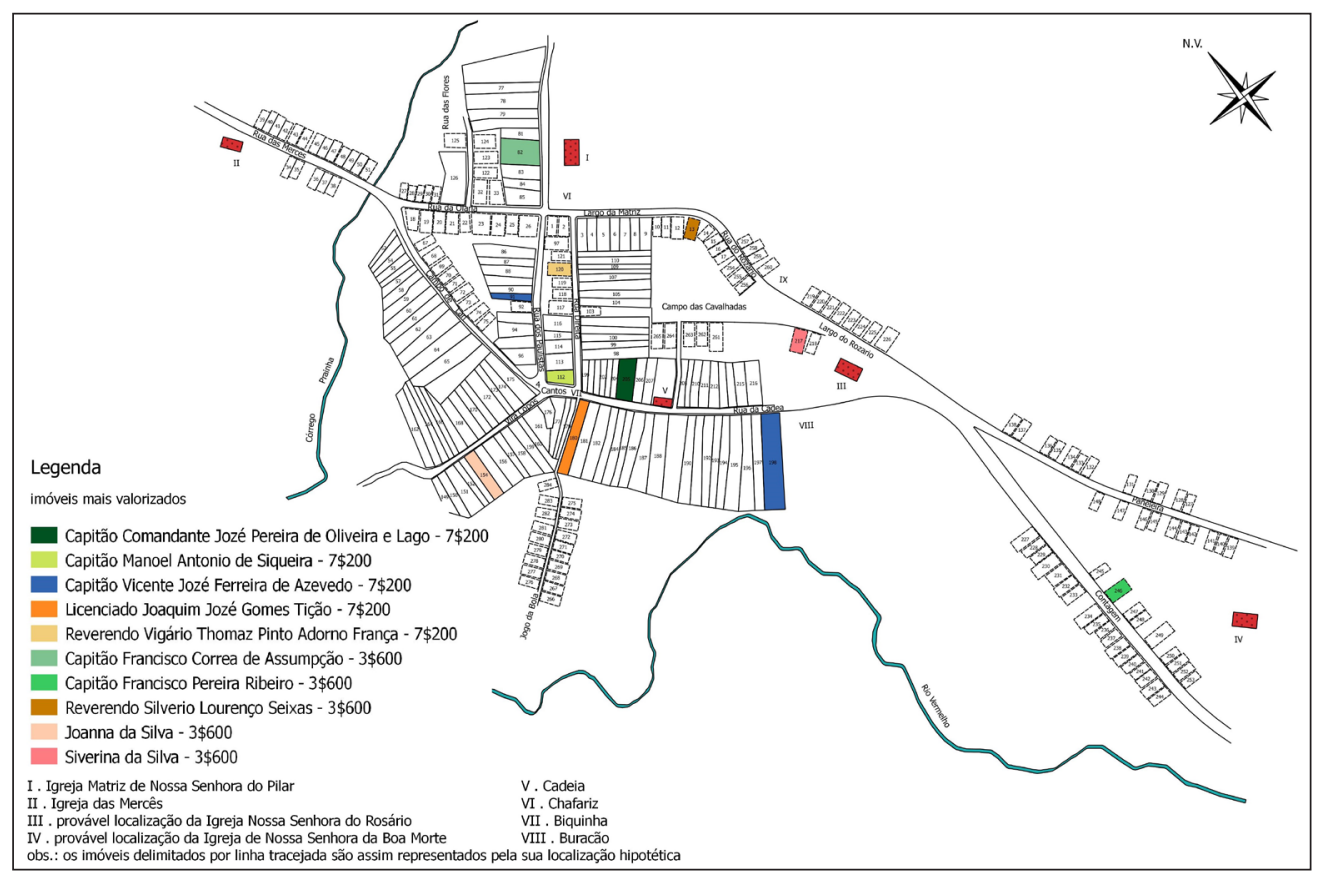

Figura 14 - Mapa de Pilar dos imóveis mais valorizados em 1816 (sem escala). (Mapa hipotético elaborado com base no Lançamento da Décima e Receita de Pilar. Fonte: Muban - Caixa 20, Pasta 1. 1.4.)

Capitão Francisco Correa de Assumpção também era proprietário de um dos imóveis mais valorizados em Pilar, correspondente à casa n 82 da Rua dos Paulistas. $\bigcirc$ rendimento anual era de $3 \$ 200$ réis, considerado satisfatório em comparação com o imóvel vizinho ( $n^{\circ} 83$ ), que estava arruinado, sendo também de sua propriedade. $\bigcirc$ capitão desempenhou um papel importante em Pilar, uma vez que foi o responsável pela tentativa de reativar a mineração no Moquem por meio da construção de um aqueduto de madeira em 1819. A função do "bicame" 104 era transportar água do Rio Vermelho para viabilizar a ativação daquelas minas, que só funcionavam no tempo das águas. Mesmo depois de uma obra de tal vulto, 105 Pohl testemunha que nada ouviu "dizer sobre a extração de
102. Bertran, 2010, p. 152.

103. A união do casal consta como a primeira referência à Igreja Matriz de Nossa Senhora do Pilar, ocorrida em 1753 (Dubugras, 1965, p. 36).

104. A equipe da Zanettini Arqueologia encontrou nos arredores de Pilar (Fazenda Coelho) vestígios do bicame, assim como de caixas escavadas na rocha e aquedutos (Zanettini Arqueologia, 2017, p. 26).

105. De acordo com Pohl (1976, p. 189), a obra teria custado 1:800\$000 réis. 
106. Pohl (1976, p. 189).

107. Mattos (2004, p. 130)

108. Teles (1998, p. 166).

109. Usufruíam de apenas um dos imóveis, pois o outro estava arruinado.

110. Cf. Le Goff (1992). ouro que se pretendia obter com essa obra". ${ }^{106}$ Cunha Mattos ${ }^{107}$ revela quais seriam as causas do insucesso dessa empreitada: a calha não teria ficado totalmente nivelada, mas mesmo se tivesse, não teria água para transportar, devido à sua escassez. Segundo o relato de 1832 de Silva e Souza, 108 uma das causas da queda na produtividade do ouro naquela região foi justamente a escassez de água, além da utilização de métodos de extração ultrapassados e a falta de "braços africanos" para efetivar a mineração.

Do conjunto de proprietários identificados na Décima Urbana de 1816 , apenas cinco possuíam dois imóveis no núcleo urbano. Dos cinco proprietários, três usufruíam de pelo menos um dos bens: ${ }^{109}$ o Capitão Francisco Correa de Assumpção (o responsável pelo bicame), Victorina de Souza (casa $n^{\circ} 77$ - com rendimento anual de 1 \$800 réis) e o Capitão Vicente Jozé Ferreira de Azevedo (casa n 198 - e rendimento anual de $7 \$ 200$ réis, ou seja, uma das mais valorizadas de Pilar naquele ano). Por outro lado, tanto Efigenia Francisca (proprietária de dois imóveis vizinhos na Rua das Merces - nos 37 e 38) quanto o órfão Manoel Francisco (proprietário de dois imóveis vizinhos na Rua dos Paulistas - nos 89 e 901, mesmo possuindo dois imóveis no arraial em 1816, não usufruíam deles, pois estavam arruinados.

Uma característica observada em Pilar é que os imóveis pertencentes aos mesmos proprietários, na maioria dos casos, eram casas nas quais uma estava localizada ao lado da outra. Apenas os imóveis do Capitão Vicente Jozé Ferreira de Azevedo não apresentavam essa configuração, uma vez que sua residência ficava na Rua da Cadea, e a outra propriedade estava situada na Rua dos Paulistas. Outro aspecto inusitado de Pilar é que os proprietários de imóveis alugados em 1816 possuíam apenas um bem, ou seja, alugavam a única casa que possuíam. Somente sete imóveis estavam alugados, entre eles a casa da Dona Marianna de Jesus Coelho localizada na Rua Direita $n^{\circ}$ 109, cujo rendimento anual era de $3 \$ 600$ réis, alugada para o Tenente Jozé Ferreira Coelho.

Em Pilar, os imóveis arruinados estavam entremeados na malha urbana, localizados, com maior incidência, nas zonas periféricas do arraial. Os imóveis mais valorizados, por sua vez, estavam concentrados nas ruas mais centrais do núcleo, convivendo lado a lado com vizinhos miseráveis. A espacialização da Décima Urbana revela esses aspectos próprios da sociotopografia urbana, ${ }^{110}$ ao mostrar a forma como grupos sociais distintos interagem na escala do intraurbano, formando um espaço heterogêneo. 
O arraial de Meia Ponte possuía localização privilegiada na rede urbana da Capitania de Goiás e, por esse motivo, caracterizava-se como importante entreposto comercial do século XVIII. Os caminhos que conduziam ao arraial cruzavam a capitania de leste a oeste, e também de norte a sul, compondo um dos mais importantes nós de articulação das estradas que vinham dos portos do litoral para os sertões e fronteira oeste. $\bigcirc$ arraial de Meia Ponte foi descrito pelo governador José de Almeida de Vasconcellos Soveral e Carvalho em 1773 como sendo "bem cituado [...], hum dos mais opulentos da villa, e de bom comercio". ${ }^{111} \bigcirc$ arraial estava localizado em um sítio circundado por montanhas, com destaque para os Montes Pireneus, marco na paisagem para quem seguia de Corumbá para lá. O Rio das Almas, onde se descobriu ouro no arraial, estava presente na dinâmica urbana.

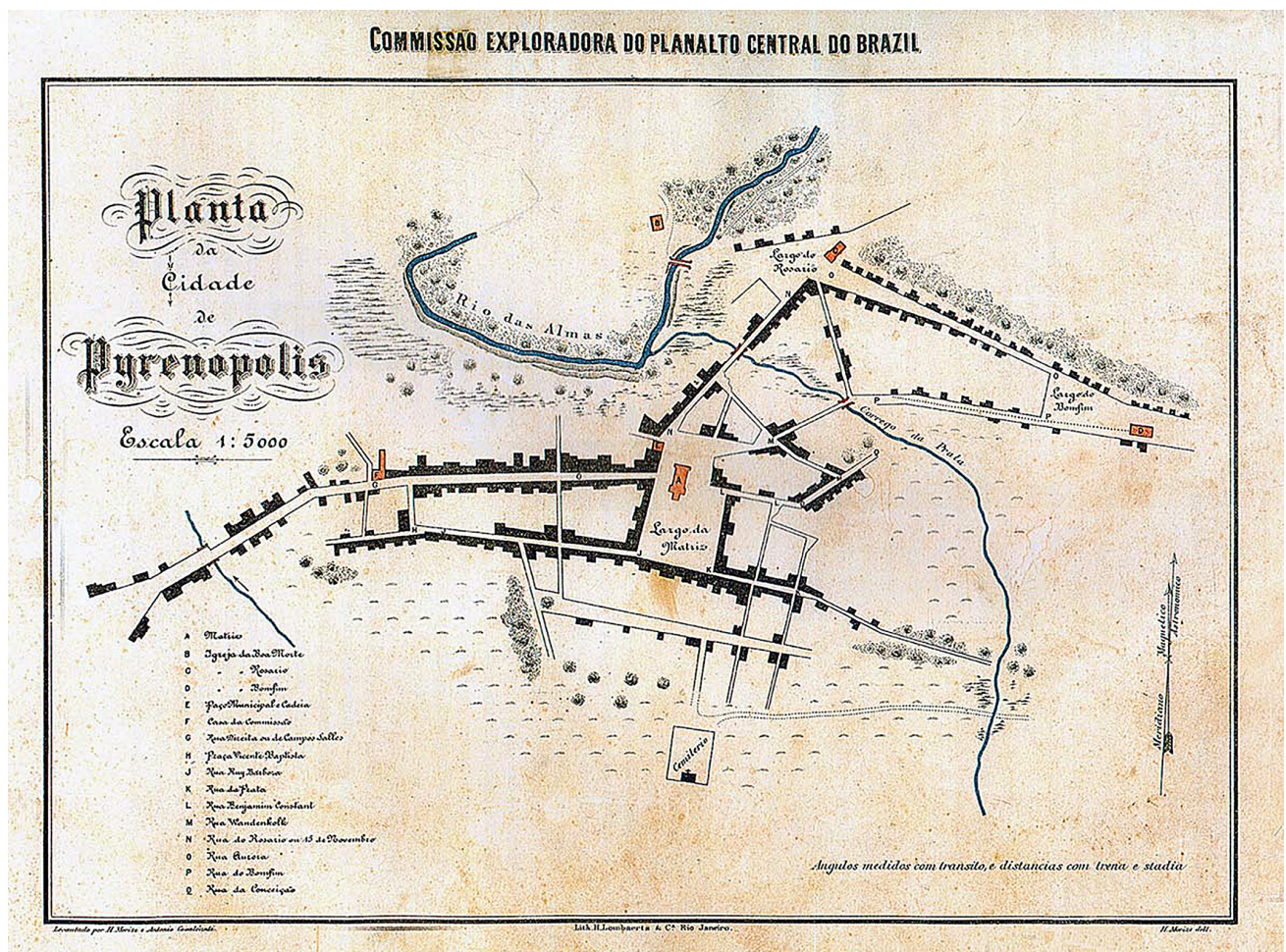

Figura 15 - Planta da cidade de Pyrenopolis - 1892. Fonte: Cruls (1894).

Pohl112 classificou as ruas de Meia Ponte, em 1818, como "retas", destacando que algumas possuíam "passeios de xisto quartzífero" e apenas uma era calçada. Observando as fotos da passagem do século XIX para $\circ$ XX, verificamos que as ruas Direita, Nova e do Rosário possuíam calçamento de pedra, 
113. As outras ruas receberam, na década de 1970 , pavimentação em "pedra pirenópolis" (rocha extraída de pedreiras de quartzito próximas à cidade), assentadas de forma a deixar evidente que se trata de uma intervenção contemporânea, compondo de forma harmônica com o conjunto arquitetônico.

114. D'Alincourt (1976, p. 90).

115. Embora não cite o nome das vias, poderia estar se referindo às atuais ruas do Bonfim, Aurora, Rosário e Direita.

116. Possivelmente as atuais ruas Santa Cruz, da Prata, Matutina, Rui Barbosa e a Rua Nova, a única que foi mencionada.

117. Mattos (1979, p. 33).

118. Assim como a Planta da Cidade de Goyaz, essa planta de Pirenópolis foi elaborada por Henri Charles Morize, membro da Commissão Exploradora do Planalto Central do Brazil chefiada pelo astrônomo Luis Cruls. A Comissão utilizou Pirenópolis como ponto de apoio para as turmas que seguiram para demarcar os limites da zona destinada à futura capital federal (Cruls, 1894).

119. Saint-Hilaire (1976, p. 36).

120. Pohl (1976, p. 116).

121. Jayme; Jayme (2003, p. 256).

122. Fonte: Muban - Caixa 19, Pasta 1.1.4. "Lançamento da Décima e Receita".

123. Outro sobrado foi detectado por Jayme e Jayme (2003, p. 165), situado na Rua Direita. As Décimas de 1810 não fazem menção a outro sobrado, o que comprova a informação dos substituído no século XX por blocos de concreto sextavados. ${ }^{113}$ D'Alincourt, ${ }^{114}$ naquele mesmo ano, categorizou as ruas em dois tipos: as implantadas em sítios mais acidentados ${ }^{115} \mathrm{e}$ as ruas de sítios mais planos. ${ }^{116}$ As primeiras são classificadas como "sem ordem, nem uniformidade", e as demais foram descritas como "largas e direitas; porém menos povoadas, à exceção da Nova". Essa informação está em harmonia com a Décima Urbana de 1819, uma vez que a taxa de ocupação da Rua Nova era alta, ainda mais se comparada ao restante do arraial.

Nos áureos tempos do garimpo, a margem norte do rio das Almas equivalia a uma única data mineral, cuja propriedade era de Luciano Nunes Teixeira e seu genro, o Sargento-mor Antônio Rodrigues Frota. Eles foram os responsáveis pela construção do extinto "Castelo do Frota" e da Capela de Nossa Senhora do Monte do Carmo, atual Museu de Arte Sacra de Pirenópolis. Em 1824, Cunha Mattos revelou que a ponte sobre o rio das Almas "se acha de todo arruinada". ${ }^{117} \mathrm{Na}$ Planta da Cidade de Pyrenópolis ${ }^{118}$ de 1892, foram registradas apenas a igreja nessa margem do rio, além de uma ponte (Figura 15).

Para Saint-Hilaire, as casas de Meia Ponte, em 1818, eram "todas muito limpas, caprichosamente caiadas, cobertas de telhas e bastante altas para a região", "119 com verdes quintais, onde eram cultivados laranja e café, além de bananeiras, visíveis nas fotos do início do século XX. Nesse mesmo ano, Pohl aborda em sua descrição as características construtivas das casas, afirmando que eram térreas e "construídas de madeira e barro, caiadas e cobertas de telhas". ${ }^{120}$ Os pesquisadores Jayme e Jayme ${ }^{121}$ apontam para a existência de um sobrado na Rua do Bonfim, que teria sido edificado no início do século XIX e demolido após 1915. Confirmamos a existência desse sobrado ao cotejar essas informações com a Décima Urbana de Meia Ponte de 1810,122 na qual consta a existência de uma casa de dois pavimentos na mesma rua. ${ }^{123}$

O processo de ruralização pelo qual passou Meia Ponte ao longo do Oitocentos fica evidente ao analisar a documentação primária e os relatos de viajantes, como o de Saint-Hilaire em 1818, quando aponta que "a maioria dos habitantes de Meia-Ponte se dedica à agricultura e como só vão ao arraial aos domingos, as casas permanecem vazias durante toda a semana". ${ }^{124}$ No mesmo ano, D'Alincourt revela que aquela região era o lugar onde "melhor se cuida da agricultura". ${ }^{25}$ Esse aspecto também fica evidente na toponímia, com a alusão nos nomes dos logradouros à vida no campo, caso das ruas do Curral, dos Porcos e das Bestas.

Analisando as Décimas Urbanas de Meia Ponte, ${ }^{126}$ foi possível acompanhar o rebatimento dessas transformações no espaço do intraurbano, marcado pelo processo de ruralização e pelo declínio da economia mineradora. Para a análise da Décima Urbana o ano escolhido foi o de 1819, por se aproximar temporalmente 
dos registros dos viajantes que por lá passaram, permitindo o cruzamento de informações. Saint-Hilaire, ${ }^{127}$ D'Alincourt ${ }^{128}$ e Pohl' ${ }^{129}$ passaram por Meia Ponte em 1818, este último retornou em 1820. As narrativas dos viajantes apresentam informações relevantes, tais como as características do sítio e o estado de conservação geral do arraial e de seus principais edifícios. Outras fontes também foram muito elucidativas, como os desenhos de William John Burchell (1827) ${ }^{130} \mathrm{e}$ os relatos importantes do Oitocentos, como as Memórias Históricas do padre Silva e Souza de (1832) ${ }^{131}$ e os escritos de Cunha Mattos (1824). ${ }^{132}$ Recuando para a segunda metade do Setecentos, balizamos os dados do século XIX tendo como referência o Diário do Barão de Mossâmedes de 1773. ${ }^{133}$

A Décima Urbana de Meia Ponte de 1819 apresenta dados escassos em relação aos membros da Junta da Décima Urbana. Somente o Superintendente e - Tabelião/Escrivão foram identificados, representados pelo Ajudante Joaquim Pereira Valle ${ }^{134}$ e pelo Tenente Antonio Joze de Abrunhoza Campos, ${ }^{135}$ respectivamente. Os 308 imóveis identificados na Décima Urbana de Meia Ponte foram espacializados em 13 logradouros, a saber: Largo da Matriz, Rua das Bestas, Rua do Rozario, Rua dos Porcos, Travessa da Rua do Rozario, Rua Senhor do Bonfim, Rua de João Dias, Rua das Mentiras, Rua das Dores, Rua Nova, Rua da Prata, Rua do Curral e Rua do Rio das Almas (Figura 16).

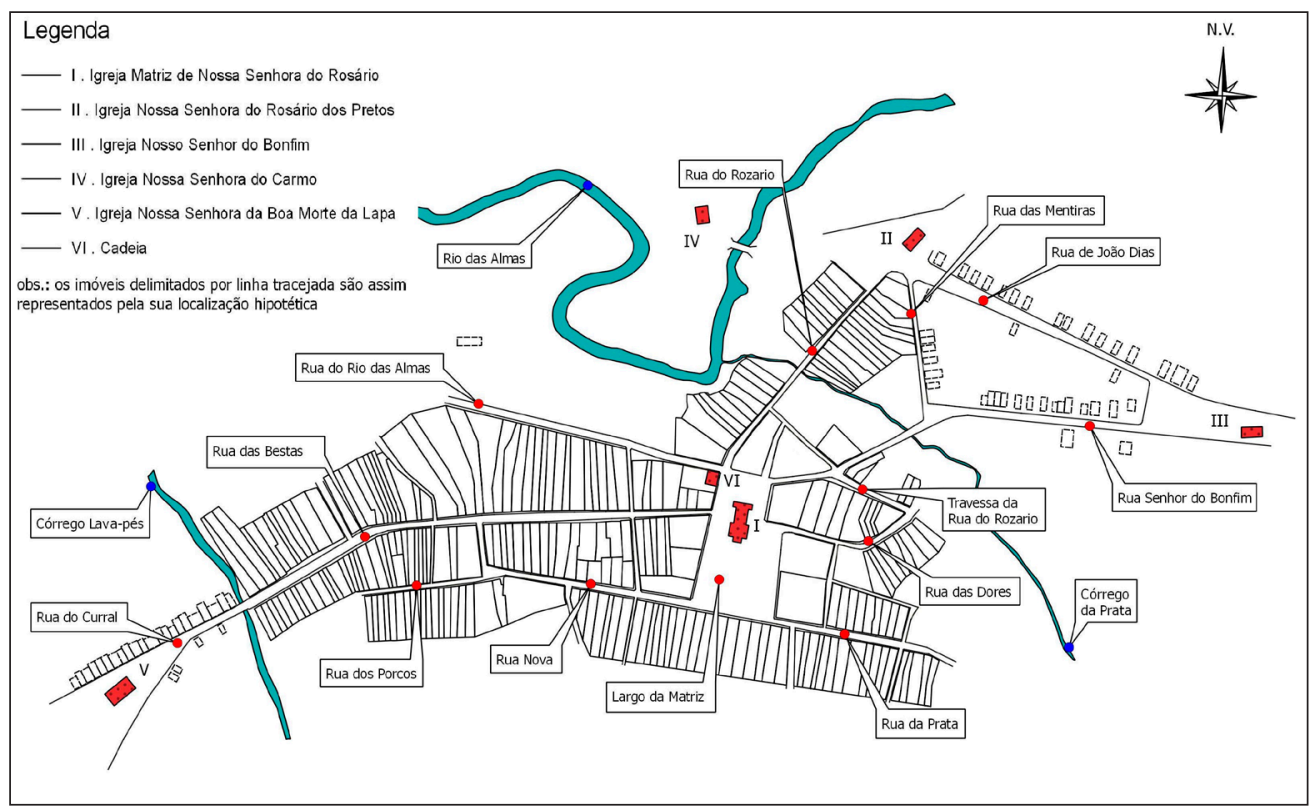

Figura 16 - Identificação dos Logradouros de Meia Ponte em 1819 (sem escala). (Mapa hipotético elaborado com base no Lançamento da Décima e Receita de Meia Ponte. Fonte: Muban - Caixa 20, Pasta 1.1.4.1 pesquisadores de que o imóvel passou por várias modificações.

124. Saint-Hilaire (1975, p.37).

125. D'Alincourt (1975, p. 90).

126. As Décimas Urbanas de Meia Ponte estão em bom estado de conservação e se encontram no Muban, onde estão arquivados os Cadernos de Lançamentos de 1810 a 1822. Encontramos no Arquivo Histórico do Estado de Goiás a Décima Urbana de Meia Ponte de 1837.

127. Cf. Saint-Hilaire (1975). 128. Cf. D’Alincourt (1975). 129. Cf. Pohl (1976).

130. Cf. Ferrez (1981).

131. Cf. Teles (1998).

132. Cf. Mattos (1979, 2004).

133. Cf. Pinheiro; Coelho (2006).

134. Proprietário da casa $\mathrm{n}^{\circ}$ 25 na Rua das Bestas.

135. Proprietário de dois imóveis na Rua do Rozario: sua residência (casa $\mathrm{n}^{\circ} 131$ ) e outro imóvel, que estava arruinado ( $\left.\mathrm{n}^{\circ} 129\right)$. 
136. Cf. Jayme; Jayme (2003).

137. Jayme; Jayme (2003, p. 232).

138. Cf. Iphan (1985).

139. Nessa espacialização ocorreram omissões das ruas do Curral e do Rio das Almas, que já constavam na Décima Urbana de 1810.

140. Cf. Jayme; Jayme (2003).

141. Jayme; Jayme (2003, p. 149, 150).
Para espacializar os dados em base cartográfica georreferenciada, a Planta da Cidade de Pyrenopolis de 1892 (Figura 15) foi essencial, por ser a cartografia mais antiga da cidade e por exibir o traçado urbano do núcleo no século XIX e sinalizar os imóveis, representados por sua testada no alinhamento das ruas. Para a espacialização dos dados, o processo foi o mesmo das outras cidades analisadas neste artigo, ou seja, a base cartográfica atual foi adaptada à realidade do início do século XIX. Com os dados sistematizados da Décima Urbana em planilha Excel importados para o Quantum Gis, trabalhamos com a espacialização dos dados em uma plataforma georreferenciada, o que viabilizou a confecção de mapas temáticos hipotéticos.

Mesmo que o mapa da cidade de 1892 disponibilize a identificação das ruas e largos, alguns nomes não coincidiam com aqueles identificados na Décima Urbana de 1819, tampouco com os nomes atuais. O livro Casas de Pirenópolis: casas dos homens ${ }^{136}$ nos auxiliou nessa tarefa e na identificação das casas, lote a lote. Nessa publicação, os pesquisadores analisaram todos os imóveis do centro histórico, discorreram sobre os aspectos dos logradouros e as antigas vocações de determinadas regiões da cidade - como a presença de uma olaria próxima às margens do Córrego da Prata, que antigamente também era conhecido por Córrego da Olaria. ${ }^{137}$

Outra importante referência, que ajudou no processo de espacialização da Décima Urbana, foi o produto realizado pelos técnicos da então $8^{a}$ DR SPHAN/ Pró-Memória durante o desenvolvimento do processo de tombamento do centro histórico de Pirenópolis. ${ }^{138}$ Embora apresente outra solução na espacialização dos dados das Décimas de 1810,139 o estudo nos forneceu subsídios para a análise da conformação urbana do arraial no início do século XIX.

A toponímia nos orientou a localizar alguns logradouros do arraial, como a antiga Rua do Curral. A principal porta de entrada de Meia Ponte era acessada atravessando o Córrego Lava-pés, seguindo pela Rua das Bestas. A partir da análise do mapa de 1892, dos escritos de Jayme e Jayme ${ }^{140}$ e do cotejamento das informações com uma foto aérea de Pirenópolis da década de 1960, chegamos à conclusão de que um trecho da região, atualmente conhecida como Alto da Lapa, corresponderia à Rua do Curral. O nome da rua faz referência a essa zona de transição, hipótese reforçada quando os pesquisadores ${ }^{141}$ apontam a existência de pastos e estalagens próximos ao Córrego Lava-pés. A Igreja de Nossa Senhora da Lapa e Boa Morte e seu largo estava localizada nessa região, que teve sua configuração urbanística bastante alterada, principalmente depois da ruína do templo, ocorrida ainda no século XIX. Por esse acesso, chegavam as tropas de Vila Boa e Cuiabá, o que justifica o nome da Rua das Bestas, já que era a continuação da Rua do Curral e rota das tropas que atravessavam o arraial rumo ao leste, com estradas para as capitanias de Minas Gerais e Bahia. 
Quando esteve em Meia Ponte em 1818, Saint-Hilaire ${ }^{142}$ contou mais de 300 casas no arraial, número próximo dos 308 imóveis identificados na Décima Urbana de 1819. Porém, aquele que mais se aproximou foi Cunha Mattos, que, em 1824, registrou 307 casas, sendo "algumas delas muy boas". ${ }^{143}$ Em 1832, Silva e Souza ${ }^{144}$ sinalizou que o arraial possuía 1.462 habitantes, distribuídos em 320 fogos. $\bigcirc$ dado apresentado pelo padre não condiz com o registrado na Décima Urbana de Meia Ponte de 1837, ${ }^{145}$ que registrou 203 casas, das quais 21 não foram tributadas por estarem "inabitadas". $\bigcirc$ processo de retração urbana era visível, sobretudo se considerar que a cada ano o número de imóveis arruinados e desocupados aumentava.

proeminente processo de ruralização de Meia Ponte abre espaço para reflexões, sobretudo se levarmos em conta a ocupação dos imóveis no arraial em 1819. De uma amostragem de 308 casas, apenas 42\% estavam ocupadas (utilizadas por seus proprietários ou alugadas); dos imóveis desocupados, $12 \%$ estavam desabitados e 46\% estavam arruinados. No ano anterior, o Capitão Comandante Joaquim Alves de Oliveira ${ }^{146}$ redigiu um documento intitulado Relação dos Habitantes aSituados no termo da Freguesia d'Nossa Senhora do Rozario, Minas d'Meia Ponte, Comarca de Villa boa d'Goyas, ${ }^{147}$ em que cadastrava as propriedades rurais ${ }^{148}$ da freguesia, distribuídas entre as regiões da Capela do Rio do Peixe, do Mato Grosso e da Capela do Corumbá. Ao cruzar os dados dessa relação com o da décima, detectamos que dos 265 proprietários rurais cadastrados, apenas 46 possuíam imóveis no arraial, dos quais 18 possuíam casas arruinadas, ou seja, sem condições de habitabilidade.

Quando relatou que as casas ficavam vazias durante a semana em função das atividades rurais de alguns dos moradores de Meia Ponte, é provável que SaintHilaire $^{149}$ estivesse se referindo aos 131 imóveis que estavam ocupados.

documento Relação dos Habitantes... identificava os proprietários que moravam em suas propriedades rurais, dos quais alguns também possuíam imóveis no arraial làs vezes, mais de um), que a Décima Urbana classificava como imóveis tributáveis e, portanto, em uso. Por exemplo, Dona Maria Jozefa Curado, 150 proprietária de dois imóveis vizinhos na Rua das Bestas (números 19 e 20), ambos de uso próprio. Dona Maria também era proprietária do Sitio do Bonfim, ${ }^{151}$ localizado na região do Mato Grosso, na estrada para Vila Boa. Não se sabe quando o sítio foi comprado por ela, ${ }^{152}$ mas em 1818 encontrava-se cultivado e possuía nove escravos. Como a proprietária residia no sítio, é possível que um dos imóveis da Rua das Bestas era sua "casa da cidade", enquanto o outro poderia desempenhar atividade comercial, uma vez que a rua era o principal acesso para quem chegava a Meia Ponte.
142. Saint-Hilaire (1976, p 36).

143. Mattos (1979, p. 33).

144. Teles (1998, p. 158).

145. Lançamento da Decima das Cazas. Villa de Meiaponte 1837. Fonte: Arquivo Histórico do Estado de Goiás - Municípios Pirenópolis - Caixa 1 de $1812-1849$

146. Um ano depois, Joaquim Alves de Oliveira jâ tinha alçado ao posto de tenente-coronel, conforme consta na Décima Urbana de 1819.

147. Documento arquivado no Arquivo Histórico do Estado de Goiás na sessão "Documentação Avulsa I Caixa 9 - 1818 - Pacote 2". Tal como fizemos no caso das Décimas Urbanas, reproduzimos os nomes das propriedades rurais e seus proprietários como estão na fonte primária, obedecendo a sua grafia original. Por essa razão, os nomes aparecem em itálico no texto.

148. Dentre elas, engenhos, sítios, chácaras e fazendas.

149. Saint-Hilaire (1975, p. 37).

150. Dona Maria Jozefa Curado era irmã do tenente-general Joaquim Xavier Curado, importante figura na política expansionista portuguesa nas regiões platinas.

151. Propriedade $\mathrm{n}^{\circ} 141 \mathrm{em}$ Relação dos Habitantes... (1818).

152. O documento Relação dos Habitantes... (1818) revela, dentre outras coisas, a forma como a propriedade chegou ao seu titular. 
153. Saint-Hilaire (1975, p. 38).

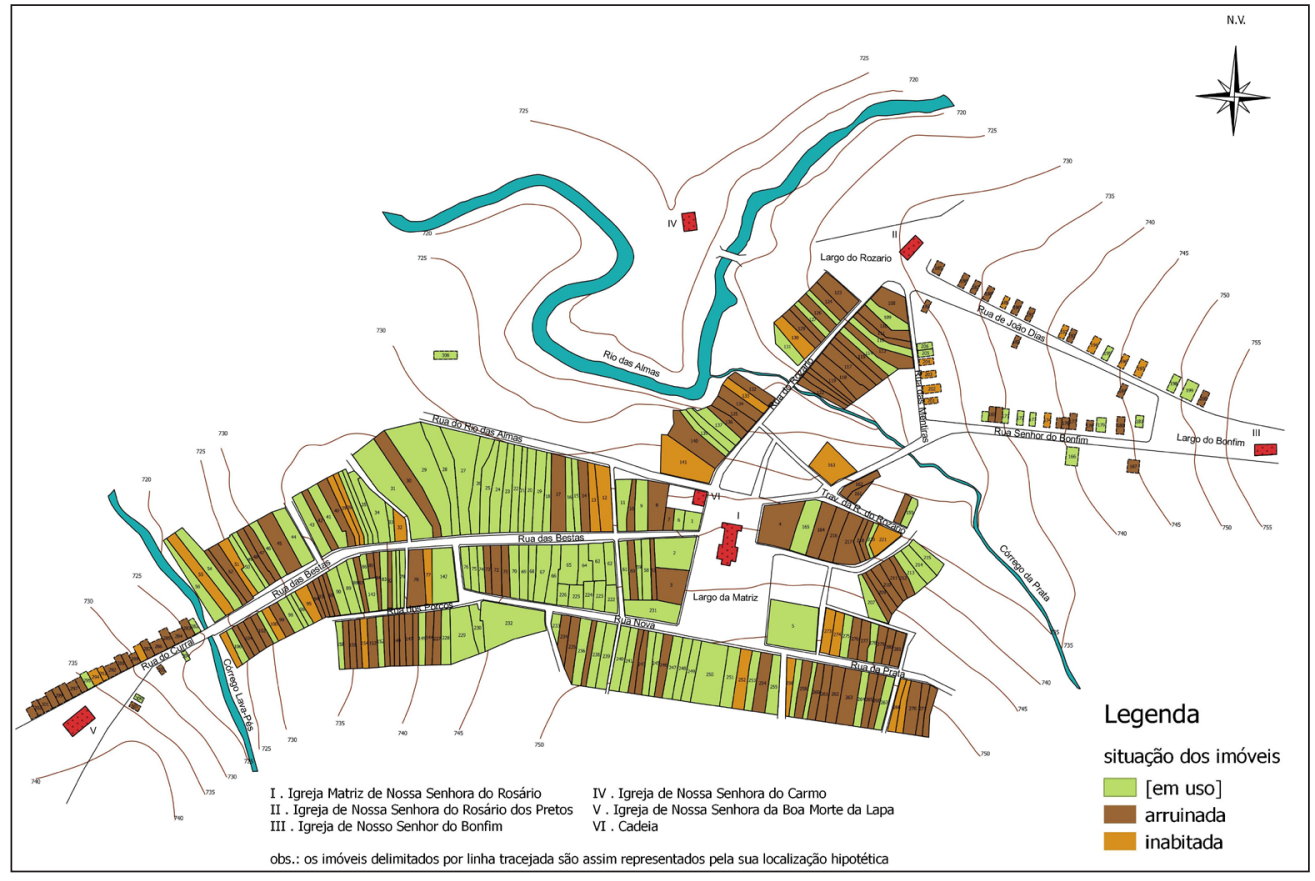

Figura 17 - Mapa de Meia Ponte da situação dos imóveis em 1819 (sem escala). (Mapa hipotético elaborado com base no Lançamento da Décima e Receita de Meia Ponte. Fonte: Muban - Caixa 20, Pasta 1.1.4.)

Considerando os imóveis desabitados e arruinados, o número assustava: de 308 imóveis, 177 casas estavam nesse estado. Isso equivale dizer que 58\% dos imóveis de Meia Ponte em 1819 estavam desocupados (Figura 17).

Ilustrando esse panorama no arraial em 1819, Saint-Hilaire ${ }^{153}$ destaca a existência de mendigos, presença esta que era queixa constante dos fazendeiros ao viajante. Curiosamente, essa parcela da população composta por pobres e miseráveis não foi identificada na Décima Urbana de Meia Ponte, como ocorreu em outros arraiais da Capitania de Goiás, como em Pilar.

A chegada ao arraial de Meia Ponte para quem vinha de Vila Boa e Cuiabá era impactante, pois causava a sensação de chegar a uma cidade fantasma. A Rua do Curral contava com somente quatro imóveis ocupados, visto que as outras 22 casas estavam arruinadas ou abandonadas. A sensação não era diferente para quem vinha do arraial vizinho de Corumbá e, consequentemente, das capitanias de Minas Gerais, Pernambuco, Bahia e São Paulo. Além da implantação das casas das ruas do Senhor do Bonfim e de João Dias ser caracterizada por casas distribuídas de modo esparso (não parede-meia), pouquíssimas delas estavam ocupadas: apenas sete na primeira rua e três na segunda. Os outros imóveis estavam na mesma situação da Rua do Curral, arruinados ou desocupados. 
Outras ruas, como a do Rozario lespecialmente no sentido da lgreja de Nossa Senhora do Rosário dos Pretos), das Dores, dos Porcos, do Curral e a Travessa do Rozario, apresentavam grande índice de casas desocupadas, uma vez que a maioria já se encontrava arruinada. A Igreja do Rosário dos Pretos testemunhou esse processo de desalento e esvaziamento de sua vizinhança ao longo do século XIX, mas veio a ruir apenas na primeira metade do século XX, fruto de uma obra mal executada (Figura 18). Atualmente a Rua do Rosário é mais conhecida por Rua do Lazer, por concentrar o polo gastronômico turístico de Pirenópolis.

cenário melhorava ao percorrer as ruas mais centrais, sobretudo na porção oeste do Largo da Matriz. A taxa de ocupação dos imóveis era maior, principalmente na rua das Bestas e na rua Nova, logradouros onde também se concentravam os imóveis mais valorizados do arraial (Figura 19). Por exemplo, o imóvel n² 232 na Rua Nova, pertencente ao Tenente-Coronel Joaquim Alves de Oliveira, e a casa $n^{\circ} 56$ na Rua das Bestas, conhecida por estalagem, de propriedade dos herdeiros de Lourenço Fernandes, ambas com rendimento anual de 21 \$600 réis. Os herdeiros de Lourenço Fernandes e o Tenente-Coronel Joaquim Aves de Oliveira possuíam outros imóveis no arraial, localizados nessas duas ruas. ${ }^{154}$ Joaquim Alves de Oliveira era figura de destaque em Meia Ponte, classificado por Cunha Mattos ${ }^{155}$ em 1824 como o "grande homem atual da Província de Goiás", sendo o responsável por fundar o primeiro jornal da província, a Matutina Meyapontense, em 1830.

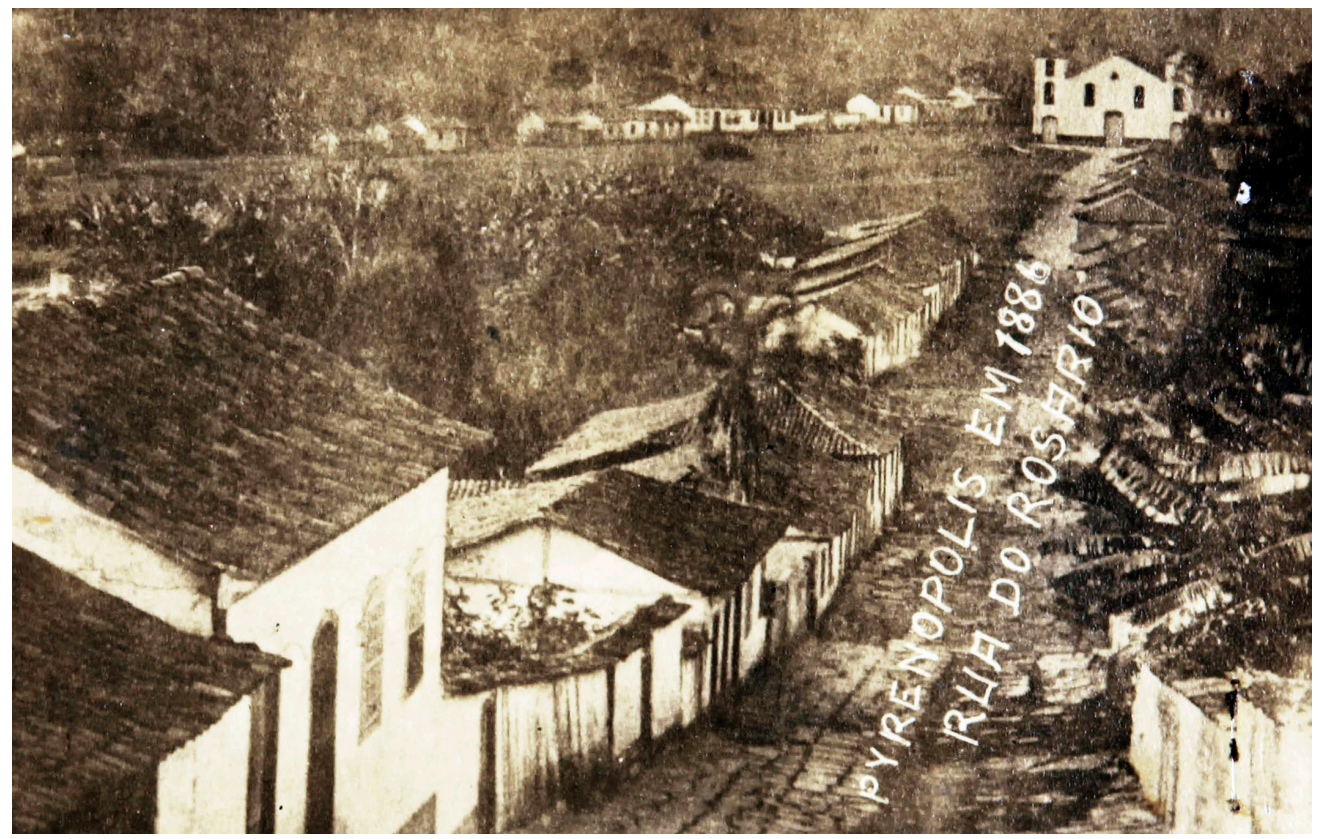

Figura 18 - Rua do Rozario com vista da lgreja de Nossa Senhora do Rosário dos Pretos em sua conformação original. Fonte: Fonte: Arquivo Central Iphan RJ.
154. Contudo, alguns desses imóveis estavam arruinados.

155. Mattos (1979, p. 91). 
156. Atual Fazenda Babilônia, importante receptivo turístico de Pirenópolis. Para maiores detalhes, conferir Costa (1978), Moura (2004) e Souza (2010).

157. Cf. Costa (1978).

158. Saint-Hilaire (1975, p. 98).

159. Saint-Hilaire (1975, p. 98).

160. Relação dos Habitantes... (1818).

161. Pohl (1976, p. 239).

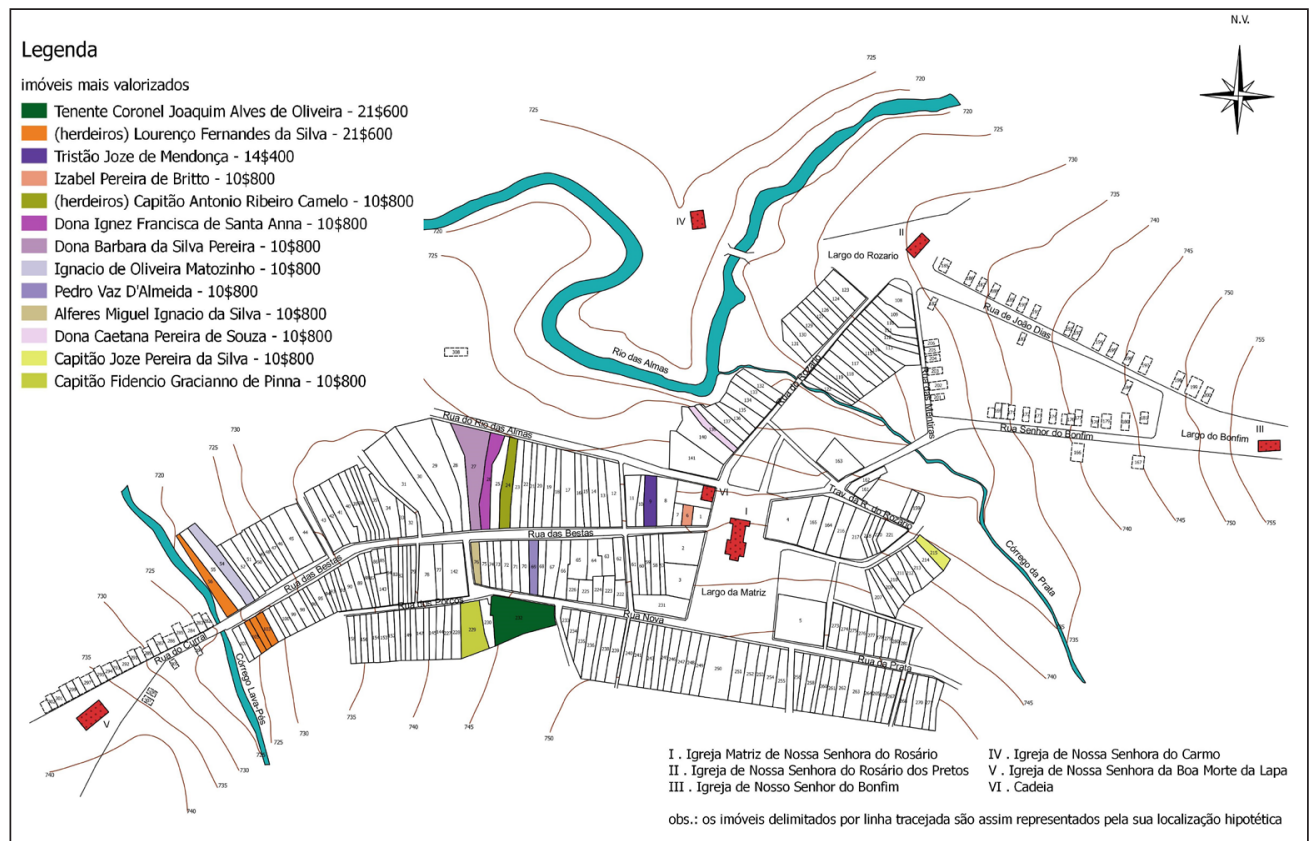

Figura 19 - Mapa de Meia Ponte dos imóveis mais valorizados em 1819 (sem escala). (Mapa hipotético elaborado com base no Lançamento da Décima e Receita de Meia Ponte. Fonte: Muban - Caixa 20, Pasta 1.1.4.1

○ "Comendador", como também era conhecido, viajava bastante e comercializava algodão e açúcar produzidos em sua propriedade rural, o Engenho São Joaquim. ${ }^{156}$ Suas viagens ao litoral geralmente duravam seis meses de ida e volta, as quais trazia para Meia Ponte produtos diversos, como sal, ferro, pólvora e tecido. ${ }^{157}$ Saint-Hilaire ${ }^{158}$ aponta que Joaquim Alves de Oliveira já se dedicou ao comércio, mas tinha maiores interesses como produtor agrícola, optando por "renunciar quase que inteiramente aos seus interesses mercantis", embora não os tenha abandonado completamente. Voltava-se às transações comerciais somente quando "esperava poder obter um lucro razoável". ${ }^{159}$

De acordo com a Relação dos Habitantes... ${ }^{160}$ redigida pelo próprio Joaquim Alves de Oliveira, o Engenho São Joaquim possuía 7.500 braças de frente e 6.000 braças de fundo e estava em parte cultivado. $\bigcirc$ Comendador possuía 86 escravos, o maior número cadastrado nas propriedades rurais da Freguesia de Nossa Senhora do Rosário de Meia Ponte. O conjunto era composto por uma casa sede conjugada ao engenho e uma grande senzala que dava para a frente da casa. Da senzala, só restaram vestígios arqueológicos em meio ao pasto. $\bigcirc$ Engenho São Joaquim, localizado na região do Mato Grosso (na estrada que ligava o arraial de Meia Ponte à Vila Boa), foi descrito por Pohl como "um dos maiores engenhos de açúcar do Brasil". ${ }^{161}$ 
Além dos imóveis números 230, 232, 233, 241 e 242 162 na Rua Nova e da casa $n^{\circ} 71^{163}$ na Rua das Bestas, o Comendador ainda era proprietário da famosa casa das 365 janelas. O exemplar, tido como o "maior edifício residencial de Meia Ponte", 164 foi demolido na segunda metade do século XIX e não foi registrado na Décima Urbana de 1819.

A Estalagem, conforme mencionado, pertencia aos herdeiros de Lourenço Fernandes. Entretanto, Jayme e Jayme ${ }^{165}$ atribuem a titularidade da propriedade ao Tenente-Coronel Joaquim Alves de Oliveira, informação que vai de encontro com as informações da Décima Urbana da Villa de Meia Ponte de 1837. $160 \bigcirc$ terreno onde estava a estalagem era muito grande e o imóvel "destinava-se, especialmente, a hospedagem de viajantes, tropeiros etc.". 167 Os herdeiros de Lourenço Fernandes também eram proprietários de outros três imóveis do outro lado da Rua das Bestas (casas números 103, 104 e 105) em 1819, todos arruinados.

\section{Tabela 3 - Imóveis mais valorizados no arraial de Meia Ponte em 1819}

\begin{tabular}{|l|l|l|}
\hline Logradouro & Proprietário e morador & Rendimento anual \\
\hline Rua Nova, 232 & Tenente Coronel Joaquim Alves de Oliveira & $21 \$ 600$ réis \\
\hline Rua das Bestas, 56 & (herdeiros) Lourenço Fernandes [da Silva] & $21 \$ 600$ réis \\
\hline Rua das Bestas, 9 & Tristão Joze de Mendonça & $14 \$ 400$ réis \\
\hline Rua das Bestas, 6 & Izabel Pereira de Britto & $10 \$ 800$ réis \\
\hline Rua das Bestas, 24 & (herdeiros) Capitão Antonio Ribeiro Camelo & $10 \$ 800$ réis \\
\hline Rua das Bestas, 26 & Dona lgnez Francisca de Santa Anna & $10 \$ 800$ réis \\
\hline Rua das Bestas, 27 & Dona Barbara da Silva Pereira & $10 \$ 800$ réis \\
\hline Rua das Bestas, 54 & lgnacio de Oliveira Matozinho & $10 \$ 800$ réis \\
\hline Rua das Bestas, 69 & Pedro Vaz D'Almeida & $10 \$ 800$ réis \\
\hline Rua das Bestas, 76 & Alferes Miguel lgnacio da Silva & $10 \$ 800$ réis \\
\hline Rua do Rozario, 139 & Dona Caetana Pereira de Souza & $10 \$ 800$ réis \\
\hline Rua das Dores, 215 & Capitão Joze Pereira da Silva & $10 \$ 800$ réis \\
\hline Rua Nova, 229 & Capitão Fidencio Gracianno de Pinna & $10 \$ 800$ réis \\
\hline
\end{tabular}

Tabela elaborada com base no Lançamento da Décima e Receita de Meia Ponte. Fonte: Muban Caixa 20, Pasta 1.1.4.

Cruzando dados referentes aos proprietários dos imóveis mais valorizados de Meia Ponte (Tabela 3) que também possuíam propriedades rurais arroladas na Relação dos Habitantes..., ${ }^{168}$ constatamos a predominância de homens com patentes militares. Caso do Alferes Miguel Ignacio da Silva, proprietário do Engenho de Santo Antonio e Almas, ${ }^{169}$ onde residia e era atendido por 10 escravos. No arraial, era proprietário de uma das casas mais valorizadas em 1819,
162. Imóvel arruinado.

163. Imóvel arruinado.

164. Jayme; Jayme (2003, p 292).

165. Jayme; Jayme (2003, p. 149).

166. Na Décima Urbana desse ano, o imóvel está registrado como $\mathrm{n}^{\circ} 1$. Cf. Lançamento da Décima.. (1837).

167. Jayme; Jayme (2003, p. 149).

168. Conferir sítio 263 em Relação dos Habitantes...

169. Conferir propriedade $\mathrm{n}^{\circ} 161$ em Relação dos Habitantes.. 
170. O Reverendo foi Capelão da Capela Curada de Nossa Senhora da Penha da França, em Corumbá (Jayme; Jayme (2003, p. 246).

171. Conferir sítio 263 em Relação dos Habitantes...

172. Jayme; Jayme (2003, p. 246).

173. Jayme; Jayme (2003, p. 310)

174. Casou-se com Ana Timótea Curado, irmã de Dona Maria Jozefa Curada, citada anteriormente (Jayme; Jayme, 2003, p. 310).

175. De acordo com Jayme e Jayme (2003, p. 310), o Sargento-mor Antônio José de Campos teria sido o responsável por calçar em pedras a estrada do Morro Grande, no caminho de Meia Ponte para Jaraguá, de modo a facilitar o acesso a suas propriedades rurais. A pavimentação em pedras desse trecho da estrada foi descrita por Saint-Hilaire (1975, p. 35).

176. Jayme; Jayme (2003, p. 310).

177. Grafia tal como se encontra na fonte primária Relação dos Habitantes... (1818). localizada na Rua das Bestas $n^{\circ} 76$, cujo rendimento anual era de $10 \$ 800$ réis. Assim como Dona Maria Jozefa Curado, o alferes mantinha uma casa no arraial para visitas esporádicas. $\bigcirc$ engenho, fruto de herança, era vizinho do Engenho São Joaquim, do Tenente-Coronel Joaquim Alves de Oliveira.

A quantidade de pessoas que possuíam mais de um imóvel no arraial em 1819 era alta, o que não significa que elas eram abastadas, considerando que a maioria dos imóveis estavam desocupados ou arruinados. Essa era a situação dos dois imóveis do Reverendo Francisco Ignacio de Faria Vivas, ${ }^{170}$ que não estavam sendo utilizados. Uma casa, localizada na Rua do Rozario n ${ }^{\circ}$ 141, estava desabitada, e a outra na Rua dos Porcos n ${ }^{\circ} 144$ encontrava-se em situação de ruína. O padre possuía um sítio na região da Capela do Rio do Peixe com parte de sua terra cultivada, onde viviam e trabalhavam sete escravos. Conforme consta na Relação dos Habitantes..., ${ }^{171}$ o pároco não vivia no Sitio de São João, mas no arraial. Ao procuramos onde seria sua residência, uma vez que esses imóveis não estavam em condições de uso, vislumbramos que o padre vivia com Anna Francisca D’Melo, sua companheira. De acordo com a Décima Urbana de 1819, Anna Francisca residia na casa $n^{\circ} 80$ na Rua das Bestas, cujo rendimento anual era de $9 \$ 000$ réis. Da união de Anna Francisca D’Mello com o Reverendo Francisco Ignacio de Faria Vivas nasceu o Capitão Francisco Inácio de Faria Vivas, ${ }^{172}$ homônimo do seu pai como era comum naquela época.

Dos herdeiros dos antigos expoentes da exploração aurífera da região, alguns apareceram discretamente na Décima Urbana de Meia Ponte de 1819, caso dos filhos do Sargento-mor Antônio José de Campos, tido por Jayme e Jayme ${ }^{173}$ como um dos "homens mais poderosos da velha Meia-Ponte, no século XVIII". O sargentomor era português, casou-se em Meia Ponte em meados de $1750^{174}$ e era proprietário das fazendas Bagagem, Cabaceiros e Buraco, situadas entre Corumbá e Meia Ponte. ${ }^{175}$ Vivia em trânsito constante com a Bahia, de onde trouxe uma caravana com 260 escravos, juntamente com a grande imagem do Cristo Crucifixado para colocar no altar-mor da lgreja de Nosso Senhor do Bonfim ${ }^{176}$ que mandou construir.

O Tenente Antonio Joze Abrunhoza Campos (o tabelião/escrivão da Décima Urbana de Meia Ponte) e o Reverendo Jeronimo Joze Campos são os filhos do Sargentomor e possuíam imóveis cadastrados na Décima Urbana de Meia Ponte em 1819. Os irmãos eram proprietários de casas vizinhas, situadas na Rua do Rozario. $\bigcirc$ imóvel do religioso de $n^{\circ} 131$ estava arruinado, bem como a casa no 129 do Tenente Antonio Joze Abrunhoza Campos, que morava logo ao lado na casa de n 132 . O Reverendo Jeronimo Joze Campos manteve na família duas das propriedades rurais que no século XVIII eram produtoras de ouro: o Sítio dos Cabasseiros ${ }^{177}$ e o Engenho da Bagagem, onde residia. As duas propriedades foram compradas por ele e não herdadas de seu 
pai, o que nos induz a pensar que provavelmente o religioso teria comprado dos outros herdeiros. Ambas estavam cultivadas, embora não possuíssem grandes dimensões e apresentassem um número pequeno de escravizados na lida. $\bigcirc$ Engenho da Bagagem ${ }^{178}$ possuía 750 braças de frente por 750 braças de fundo e contava com 6 escravos, ao passo que o Sítio dos Cabasseiros ${ }^{179}$ contava com apenas um, em um terreno de 375 braças de frente com 750 braças de fundo.

A situação em que se encontravam os herdeiros do Sargento-mor Antônio Rodrigues Frota era mais crítica que a dos filhos do Sargento-mor Antônio José de Campos, tanto que Saint-Hilaire 180 relatou que as filhas do "rico minerador", "dono de numerosos escravos", viviam de esmolas em 1818. De acordo com Jayme e Jayme, ${ }^{181}$ o Sargento-mor Antônio Rodrigues Frota e sua esposa Maria de Jesus tiveram 12 filhos, sendo 7 mulheres e 5 homens. Os homens não ficaram em Meia Ponte, ao contrário das filhas - Damásia, Inês, Maria Quitéria, Inácia, Gertrudes e Luíza. Não foram encontrados imóveis na Décima Urbana de 1819 no nome de nenhuma delas.

Chama atenção a ausência do "Castelo do Frota" no arrolamento de imóveis das Décimas Urbanas de Meia Ponte, uma vez que o imóvel ainda existia naquela época, tendo sido registrado nas ilustrações de Burchell em 1827 e descrito por Saint-Hilaire como uma casa que teria "sido muito bonita em outros tempos" e que se "ressaltava agradavelmente no meio da paisagem". ${ }^{182}$ Uma hipótese para o fiscal não ter cadastrado esse e outros imóveis existentes em Meia Ponte naquela época diz respeito à abrangência da coleta do imposto, já que a Décima Urbana incidia apenas sobre imóveis urbanos.

Nessa zona de fronteira indefinida, outra casa famosa da história da cidade também não foi catalogada na décima, o "casarão de 365 janelas" do Tenente Coronel Joaquim Alves de Oliveira, localizado no pasto conhecido por "Anduzeiro". ${ }^{183}$ Esse argumento poderia justificar a ausência do "Castelo do Frota" nas Décimas Urbanas, uma vez que a margem norte do Rio das Almas também poderia ser considerada zona rural, portanto, fora da poligonal da tributação.

Como vemos, os limites entre os núcleos urbano e rural eram bastante subjetivos. Reforçando a relação de interdependência do campo com a área urbana, isso se reflete nos nomes dos logradouros, como na Rua dos Porcos, Rua das Bestas ou Rua do Curral, localizadas na extremidade oeste do arraial, conforme tratado anteriormente.
178. Ou Engenho da Bagajem, como foi identificado sob o n 93 na Relação dos Habitantes... (1818).

179. Conferir sítio n ${ }^{\circ} 264$ na Relação dos Habitantes... (1818).

180. Saint-Hilaire (1975, p. 41).

181. Jayme; Jayme (2002, p. 290).

182. Saint-Hilaire (1975, p. 41).

183. Cf. Jayme; Jayme (2003). 
184. Pohl (1976, p. 272).

185. Ibid. (p. 270).

\section{NATIVIDADE}

arraial de Natividade estava localizado a uma distância de 24 léguas de onde se encontrava o Registro do Duro, ${ }^{184}$ portal de acesso para as capitanias de Pernambuco e Bahia e currais do São Francisco. A conexão com o Pará se dava via Porto Real, de onde seguia pelo rio Tocantins. As principais estradas do norte confluíam próximo ao arraial, ligando-o à Vila de São João da Palma, Porto Real, Carmo e Arraias, dentre outros arraiais da Capitania de Goiás. Em uma época em que as estradas demonstravam sinais de desgaste em função da falta de manutenção, potencializadas pela crise da extração aurífera, o caminho até Natividade se apresentava favorável. Pohl, ao seguir do Arraial de Chapada da Natividade em direção a Natividade, passou por uma "sólida ponte de madeira, de quatro braças de comprimento e duas de largura - coisa muito rara nessa região [...]"185 em 1819.

A origem do arraial de Natividade ainda é um mistério, uma vez que não existe um consenso quanto à ocupação inicial do núcleo urbano. Uma das hipóteses é que o arraial poderia ter se iniciado no alto da Serra de Natividade, sendo transferido depois para um lugar mais acessível; outra possibilidade é que o arraial do alto da serra seria o de São Luís e que teria existido simultaneamente com o de Natividade; a última possibilidade é que os vestígios arqueológicos no alto da serra seriam apenas testemunhos da área de garimpo e o arraial onde atualmente está a cidade teve seu nome alterado de São Luís para Natividade em idos de 1740. De uma forma ou de outra, a Serra de Natividade exerceu uma grande importância devido a sua influência direta na ocupação do arraial. $\bigcirc$ núcleo se encontra nos contrafortes da serra, para onde se dirigiam os mineradores em busca do ouro - tanto que guarda um valioso sítio arqueológico, composto por ruínas de casas de pedra, canais encravados na rocha por onde corriam água e muros de pedra conformando um reservatório de água.

Analisando a implantação do que seria o arraial de São Luís no alto da serra e de como teria se dado a transferência para o sítio de Natividade, a hipótese mais provável é a da mudança do sítio do arraial, ficando a serra apenas para a extração de ouro. Ao analisar a topografia do arraial e a maneira como as ruas foram implantadas, percebemos que houve uma preocupação prévia em estabelecer os logradouros, obedecendo as curvas de nível, dando a ilusão de que o sítio é plano. Com a experiência anterior de ocupação no alto da serra em um terreno muito acidentado e de difícil acesso, é muito provável que os moradores tenham optado por transferir o arraial para uma região com melhor oferta de água e facilidade em relação ao acesso. A implantação de Natividade segue a 
orientação norte-sul, banhado pelo Córrego da Praia (ou Prainha) a leste, que se conserva a uma pequena distância do arraial.

Cunha Mattos descreve Natividade em 1824 como um arraial "extenso, aprazível, com boas casas, belas ruas, largas praças [...]". 186 Pohl o considerava entre os maiores arraiais da Capitania de Goiás, "ocupando o segundo lugar depois de Meia Ponte". ${ }^{187}$ As casas são descritas por Pohl e Cunha Mattos como "boas casas", edificadas em "adobe e cobertas com telha cerâmica". O viajante 188 complementa que "as casas, todas térreas", seguem "enfileiradas uma ao lado da outra, [...] com quintais fechados com muros de pedras ou tijolo", constituindo "ruas largas, bastantes regulares, orladas de calçadas de xisto quartzífero". As ruas, contudo, não eram calçadas.

Os elementos arquitetônicos dos exemplares que chegaram aos dias atuais trazem claras referências à arquitetura corrente nos sertões da Bahia e de Pernambuco, diferenciando-se da arquitetura do sul da Capitania de Goiás. A conexão dessa região com esses sertões existia antes da ocupação do território da Capitania de Goiás em função da mineração, tendo se dado por meio da circulação do gado dos currais do São Francisco, que eram criados soltos. Esse intercâmbio foi intensificado a partir da segunda metade do século XIX, quando a atividade pecuária na região se consolidou e o capital passou a ser investido, dentre outras coisas, no embelezamento das casas. Elementos ornamentais da passagem do século XIX para o XX, como pilares decorativos, frisos e platibandas trabalhadas, passaram a compor as fachadas das casas do século XVIII. Essas transformações se faziam notar, inclusive, no partido arquitetônico das novas casas construídas naquela época, que obedecia às necessidades dos fazendeiros, com a inserção de novos ambientes como despensa, paiol, quarto de arreio, dentre outros. ${ }^{189}$

Em 1811, Natividade contava com 189 imóveis cadastrados na Décima Urbana. Em 1817, houve um acréscimo de 9 casas - fato digno de nota, se considerarmos que alguns arraiais de origem mineradora decresceram nesse momento, marcado pela retração da economia mineradora. No ano de 1819, Pohl contabiliza mais de 300 casas, ${ }^{190}$ número um pouco exagerado, se levarmos em consideração que cinco anos mais tarde Cunha Mattos aponta a existência de 188 fogos. ${ }^{191}$

Para a análise do núcleo urbano de Natividade, elegemos o ano de 1817, de modo a cotejar as informações com outras fontes que abordavam o arraial naquele momento: As Memórias Históricas do padre Silva e Souza 11812 e 1832), ${ }^{192}$ a narrativa de Pohl ( 181 9), ${ }^{193}$ os escritos de Cunha Mattos (1 824)194 e os relatos de viagem de George Gardner (década de 1840). ${ }^{195}$ A documentação da segunda metade do século XVIII também foi de grande valia, como o Diário do
186. Mattos (1979, p. 127). 187. Pohl (1976, p. 270). 188. Pohl (1976, p. 271). 189. Vaz (1985, p. 14). 190. Pohl (1976, p. 271). 191. Mattos (1979, p. 127). 192. Cf. Teles (1998). 193. Cf. Pohl (1976). 194. Cf. Mattos (1979, 2004). 195. Cf. Gardner (1975). 
196. Cf. Pinheiro; Coelho (2006).

197. Cf. Bertran (2010).

198. No arquivo do Muban foram localizadas as Décimas Urbanas de Natividade de 1810 a 1817.

199. O Juiz Ordinário Joaquim Joze de Cerqueira era proprietário da casa $\mathrm{n}^{\circ}$ 61 na [Rua Direita], de onde despachava como juiz, e como Superintendente da Décima Urbana, conforme consta na folha de rosto do Caderno de Lançamentos da Décima Urbana de 1817.

200. Vale ressaltar que foram cadastrados apenas imóveis do arraial de Natividade, não incorporando outros arraiais sob jurisdição do julgado de Natividade.

201. O escrivão, que também assina como tabelião, morava "grátis" na casa ${ }^{\circ} 79$ de propriedade do Sargento-Mor Pio Pinto. Certamente, era seu agregado.

202. Cf. Iphan (1984).

203. Na Décima Urbana de 1817 , o logradouro foi identificado como "Rua Nova", mesmo já tendo sido cadastrada anteriormente. Ao analisar as Décimas Urbanas dos anos anteriores, chegamos à conclusão de que na realidade se tratava da Rua Direita, por isso o nome aparece entre colchetes.

204. Logradouro sem identificação, que abriga 15 imóveis, correspondente ao outro lado da Rua [Direita].

205. Logradouro sem identificação, que abriga 1 imóvel, correspondente à continuação do Largo da Praça.

206. Logradouro sem identificação, que abriga 2 imóveis, correspondente à continuação do Largo da Matriz.
Barão de Mossâmedes de $1773^{196}$ e o apanhado de informações de 1783 provenientes da "Notícia Geral da Capitania de Goiás". 197

A Décima Urbana de Natividade de 1817, arquivada no Muban, ${ }^{198}$ encontra-se em bom estado de conservação, o que nos permite fazer essa análise. O Caderno de Lançamento da Décima Urbana de Natividade de 1817 é composto por um único volume, cujos responsáveis foram nomeados pelo Doutor Dezembargador Corregedor e Ouvidor Geral da Comarca de São João da Palma na figura de Theotonio Segurado. O Juiz Ordinário e "atual Alferes" Joaquim Joze de Cerqueira ${ }^{199}$ foi nomeado como Superintendente da Décima Urbana do Julgado de Natividade 200 daquele ano, acompanhado pelo escrivão/tabelião Honorio Joze Fernandes. ${ }^{201}$ Outras pessoas do arraial também foram nomeadas para compor a Junta da Décima Urbana, como adjuntos.

Alguns dados disponibilizados na Décima Urbana de Natividade se diferenciam de outras décimas abordadas neste artigo, uma vez que disponibilizam o valor do imóvel, o número de quartos da casa, assim como a existência de outros ambientes como varanda, cozinha e quintal. Trata-se de dados especiais, pois apresentam elementos até então inexplorados sobre as casas e que nos dão uma noção da sua dimensão, assim como revelam aspectos sociais dos seus ocupantes - sejam eles proprietários ou moradores.

Assim como ocorre nas outras localidades, os nomes dos logradouros foram alterados com o passar dos anos. Em Natividade, o processo de relacionar os nomes antigos e atuais foi facilitado, pois os logradouros da cidade possuem placas com os nomes atuais das vias e sua nomenclatura anterior. $\bigcirc$ trabalho foi complementado com o cruzamento de dados dos mapas encontrados no Processo de Tombamento de Natividade, ${ }^{202}$ dos quadros relacionando a denominação antiga e atual dos logradouros presentes na Lei Municipal n $n^{\circ}$ 12/90 e de conversas com pessoas da cidade. A análise cartográfica, todavia, foi dificultada em função da ausência de mapas de época. A cartografia mais antiga encontrada na cidade foram mapas da década de 1970, além dos mapas do Processo de Tombamento (Figura 20). Como base para espacializar a Décima Urbana de Natividade de 1817, utilizamos a planta digital da cidade disponibilizada pelo Iphan.

A Décima Urbana de 1817 cadastrou 198 imóveis dispostos em 10 ruas, 1 beco, 3 largos e 3 logradouros sem identificação. Conseguimos detectar as vias não identificadas tendo como base as décimas dos anos anteriores, cujos nomes estão inseridos entre colchetes. Dessa forma, foram localizados imóveis na Rua Nova, Rua da São Benedito, Rua [Direita], ${ }^{203}$ (vazio), ${ }^{204}$ Rua do Cruzeiro, Rua dos Caxoros, Rua dos Fuzis, Largo da Viuva, Largo da Praça, (vazio), ,205 Rua da Matriz, Largo da Matriz, (vazio), 206 Rua da Contage e Beco de São Benedito (Figura 21 ). 


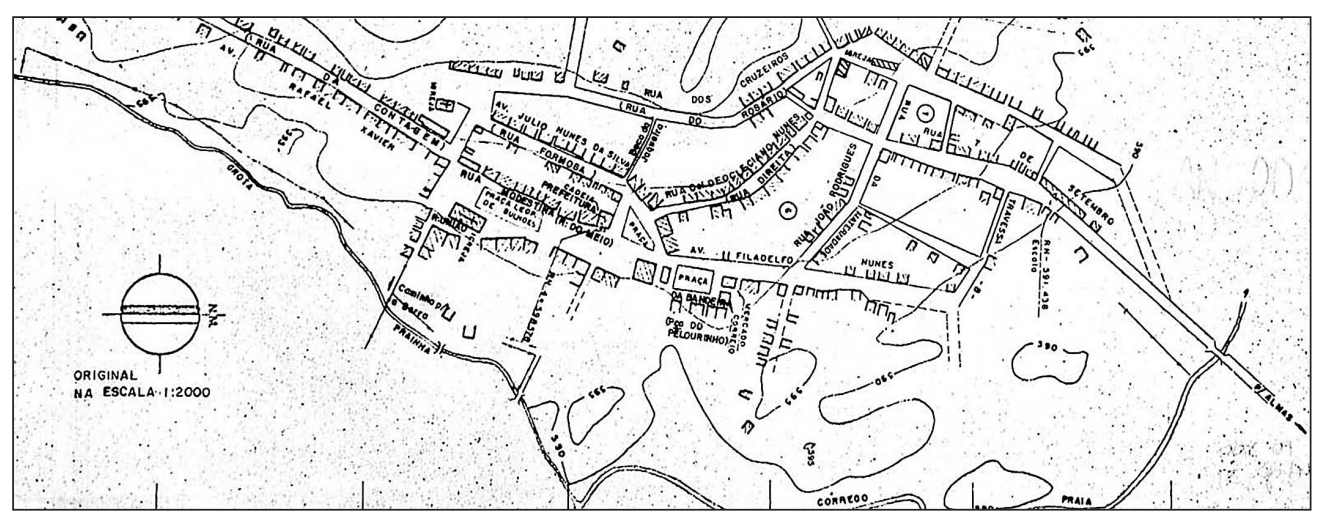

Figura 20 - Detalhe da Planta Semi-cadastral da Cidade de Natividade/GO baseada na Planta Levantada pela Saneago em fevereiro de 1976. Fonte: Iphan (1984).

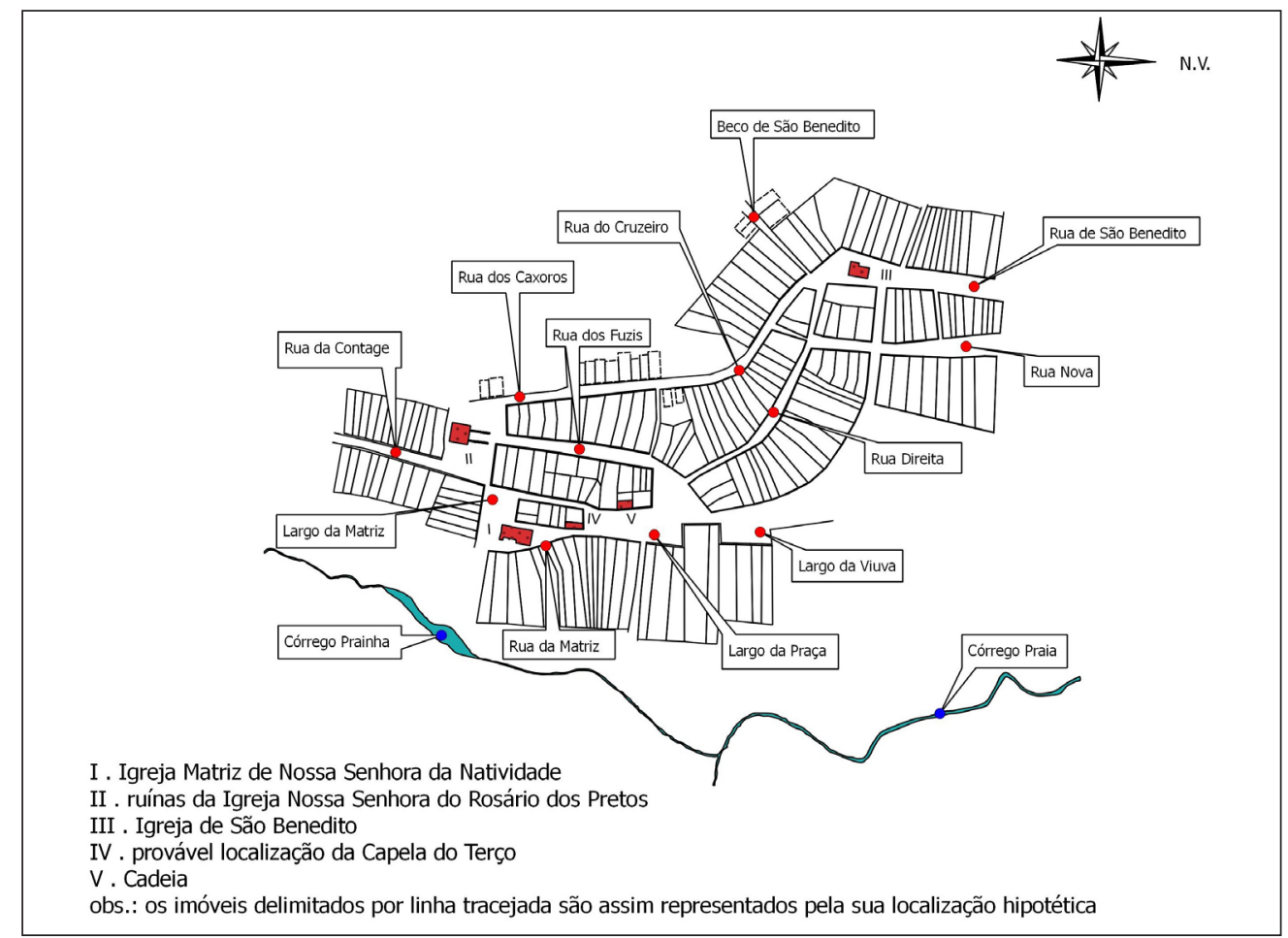

Figura 21 - Identificação dos Logradouros de Natividade em 1817 (sem escala). (Mapa hipotético elaborado com base no Lançamento da Décima e Receita de Natividade. Fonte: Muban - Caixa 20, Pasta 1.1.4,1

A toponímia apresenta pistas de equipamentos extintos, como a antiga Contagem e a extinta lgreja do Terço. A Rua da Contage, localizada na saída sul de Natividade, revela a existência de um posto fiscal na estrada que conduzia aos arraiais de Conceição e Arraias. Na Rua da Matriz foi cadastrado o imóvel n 156 , pertencente à Secretaria do Terço, provavelmente irmandade do templo de mesmo 
207. Rodrigues (1978, p. 47 , 48).

208. Pohl (1976, p. 22).

209. Teles (1998, p. 180, 181).

210. "Ofícios e Ocupações - Pessoas com Diversos Cargos III - de 1782 a 1822". Cx. 175, Pasta 4.1.35. Fonte - Muban.

211. Requerimento do Tenente de Milicias Joze Bernardino de Sena Ferreira, que coloca seu cargo de Administrador dos Rendimentos Reais do Julgado de Natividade à disposição de Vossa Majestade. - Fonte Muban - "Ofícios e Ocupações - Pessoas com Diversos Cargos III - de 1782 a 1822". Cx. 175, Pasta 4.1.35.

212. A casa $n^{\circ} 144$ do tenente foi representada nos mapas com linha tracejada, uma vez que na Décima Urbana de 1817 não especifica o nome do logradouro, que estimamos ser o Largo da Praça, seguindo a lógica do fiscal, que segue adiante pela Rua da Matriz.

213. Mattos (2004, p. 183). nome. De acordo com Rodrigues, ${ }^{207}$ a igreja estava localizada na Rua da Praça e estimamos que estivesse na esquina com a então Rua do Terço, cadastrada na Décima Urbana de 1817 como Rua da Matriz. A toponímia confirma a localização de outros logradouros, principalmente nos casos da Rua de São Benedito, Rua da Matriz e Largo da Matriz. A Rua do Cruzeiro manteve seu nome ao longo dos anos e a toponímia se aplica muito bem nesse caso, uma vez que no trecho central da rua do lado ocidental existiam alguns cruzeiros. A identificação dos largos foi facilitada mais uma vez tendo como referência a toponímia, como exemplo o Largo da Matriz e o Largo da Praça. Mesmo assim, a espacialização dos dados não foi fácil, situação que se repetiv em todos os núcleos, pelos motivos apontados anteriormente.

Mesmo que Pohl tenha classificado o comércio de Natividade de 1819 como "muito insignificante" 208 ou que Silva e Souza tenha apontado em "Memórias Estatísticas da Província de Goyaz" que na transição de arraial para vila em 1832 "não há no Termo huma loja, que se possa chamar tal; por meio de mascateação há no Termo 10, e alguns cominissões [sic] que vendem os gêneros da terra", ${ }^{209}$ encontramos documentos ${ }^{210}$ que comprovaram movimentação comercial em 1808 no arraial. É o caso do Capitão Raymundo Fernandes Pereira e do Tenente Zacarias Antonio dos Santos, proprietários de imóveis em 1817 e que viviam do "seo negocio de fazenda seca". No ano seguinte, o Tenente Joze Bernardino de Senna Ferreira chegou a colocar o seu ofício de Administrador dos Rendimentos Reais do Julgado de Natividade à disposição por não ter mais condiçães de continuar no cargo, iá que precisava se deslocar para a Praça da Bahia ${ }^{211}$ e dependia financeiramente dos seus acordos comerciais.

Dois desses comerciantes figuram entre os grandes proprietários de Natividade, ambos moradores do Largo da Praça. A casa n 126 era a mais valorizada do arraial (cujo rendimento anual era de $24 \$ 000$ réis) e pertencia ao Capitão Raimundo Fernandes Pereira. Trata-se de um grande imóvel, composto por 11 quartos, varanda, cozinha e quintal, situado em posição de destaque no largo, próximo ao Largo da Viuva. Implantada do outro lado do Largo da Praça estava a casa n 144, de propriedade do Tenente Joze Bernardino Senna Ferreira, composta por 7 quartos, cozinha e quintal, com rendimento anual de $21 \$ 000$ réis. $\bigcirc$ terreno onde estava implantada a propriedade ${ }^{212}$ era menor que a do Capitão, e estimamos que dividisse a fachada frontal com a extinta lgreja do Terço, ambos voltados para o largo.

Os dois vizinhos eram figuras de destaque no cenário político local. $\bigcirc$ Capitão Raimundo Fernandes Pereira era comandante do arraial quando Cunha Mattos $^{213}$ passou por Natividade em 1824. O Tenente Joze Bernardino Senna Ferreira, por sua vez, era defensor da separação da Comarca do Norte da Capitania/Província de Goiás, tendo inclusive se dirigido até a Corte em 1823 
com o objetivo de comunicar a D. Pedro ll a criação da Província de São João da Palma. ${ }^{214} \mathrm{Na}$ ocasião, não foi recebido pelo imperador, e retornou à Natividade com a negativa dada por José Bonifácio de Andrade e Silva. $\bigcirc$ Governo Provisório do Norte teve sua vigência de 1821 a 1823, cuja sede passou por vários núcleos, até terminar em Natividade. ${ }^{215}$ Senna foi o vereador mais votado na primeira eleição da Câmara de Natividade, em 15 de julho de 1833.216

- Largo da Praça concentrava boa parte dos imóveis mais valorizados 217 de Natividade com três casas, seguido por dois na Rua do Cruzeiro e apenas um na Rua Direita, Rua Nova e Largo da Matriz. Desses, somente o imóvel de Maria Joaquina Gomes estava alugado; os demais estavam ocupados por seus proprietários. Isso não quer dizer que a vizinhança desses logradouros era composta exclusivamente por pessoas abonadas, uma vez que foram identificadas duas moradoras miseráveis, proprietárias de casas no Largo da Praça, vivendo lado a lado com a elite local. A sociotopografia revela que pessoas de classes variadas conviviam na mesma vizinhança, da mesma forma que encontramos imóveis mais valorizados próximos a outros que sequer foram taxados.

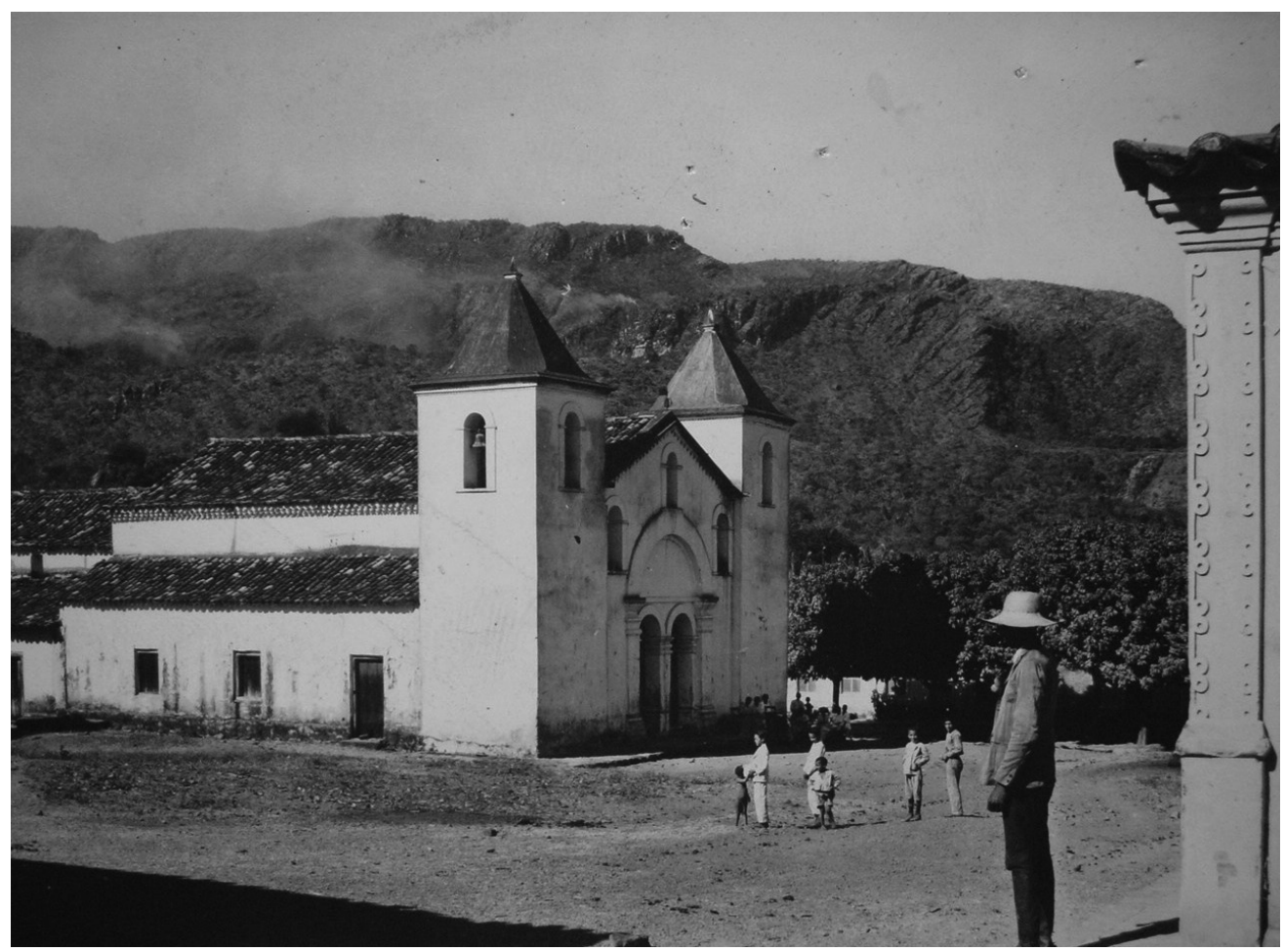

Figura 22 - Igreja Matriz de Nossa Senhora de Natividade e Serra de Natividade ao fundo no início do século XX. Fonte: Asccuna.
214. Rodrigues (1978, p. 2829).

215. Ibid. (p. 27-28).

216. Ibid. (p. 30-31).

217. Considerando a faixa do rendimento anual de $24 \$ 000$ réis a $18 \$ 500$ réis. 
Por outro lado, embora a Rua do Cruzeiro se configurasse como via de ligação de dois templos de irmandade dos pretos - a inacabada lgreja de Nossa Senhora do Rosário e a capela de São Benedito, a rua abrigava algumas das casas mais valorizadas de Natividade, como o imóvel no 83 de Maria Joaquina Gomes e a casa n ${ }^{\circ} 81$ de Manoel Ramalho Ortigas, proprietário de outro imóvel de n$^{\circ} 82$ na mesma rua. Caso semelhante ocorria em Vila Boa, onde foram encontrados imóveis muito valorizados nas vizinhanças de igrejas de irmandades dos pretos, quebrando o estigma da existência apenas de imóveis desvalorizados nas redondezas desses templos, pelo menos a partir do século XIX.

Conforme destacamos anteriormente, Natividade se diferenciava dos outros núcleos estudados neste artigo por apresentar na Décima Urbana o valor bruto dos bens de raiz. Ao analisar os dados, normalmente o valor do imóvel acompanhava o valor estimado do rendimento anual. Mas isso não era uma regra, considerando que em alguns poucos casos não percebemos uma correlação muito clara entre o valor estipulado pelo rendimento anual do imóvel e o valor do imóvel (Tabela 4).

\section{Tabela 4 - Imóveis mais valorizados no arraial de Natividade em 1817}

\begin{tabular}{|l|l|l|l|}
\hline Logradouro & Proprietários & Valor do Imóvel & Rendimento Anual \\
\hline Largo da Praça, 126 & $\begin{array}{l}\text { Capitão Raimundo Fernandes } \\
\text { Pereira }\end{array}$ & $192 \$ 000$ réis & $24 \$ 000$ réis \\
\hline Rua do Cruzeiro, 83 & Maria Joaquina Gomes & $180 \$ 000$ réis & $21 \$ 000$ réis \\
\hline $\begin{array}{l}\text { (vazio) [Largo da Praça], } \\
144\end{array}$ & $\begin{array}{l}\text { Tenente Joze Bernardino Senna } \\
\text { Ferreira }\end{array}$ & $180 \$ 000$ réis & $21 \$ 000$ réis \\
\hline Rua Nova, 01 & $\begin{array}{l}\text { Vicente Rodriguez Ferreira de } \\
\text { Santo Antonio }\end{array}$ & $144 \$ 400$ réis & $18 \$ 000$ réis \\
\hline Largo da Matriz, 166 & $\begin{array}{l}\text { Reverendo Thome de Crasto } \\
\text { Carneiro }\end{array}$ & $144 \$ 000$ réis & $18 \$ 000$ réis \\
\hline Largo da Praça, 136 & $\begin{array}{l}\text { Furriel Theotonio Carlos } \\
\text { Ramalho }\end{array}$ & $144 \$ 000$ réis & $14 \$ 400$ réis \\
\hline Rua do Cruzeiro, 84 & $\begin{array}{l}\text { Joze Bernardino e Policarpia } \\
\text { de tal }\end{array}$ & $144 \$ 000$ réis & $7 \$ 200$ réis \\
\hline
\end{tabular}

Tabela elaborada com base no Lançamento da Décima e Receita de Natividade. Fonte: Muban Caixa 20, Pasta 1.1.4.

Os membros da Junta da Décima Urbana não esclareceram quais foram os critérios adotados de cotação desses bens de raiz, o que gerou dúvidas em alguns casos, por exemplo, o imóvel nº 84 pertencente a Joze Bernardino e Policarpia de tal, cujo valor foi orçado em $144 \$ 000$ réis e o seu rendimento anual seria apenas de $7 \$ 200$ réis. $O$ imóvel estava localizado em uma das ruas mais valorizadas de Natividade, possuía 7 quartos, cozinha e quintal, e estava alugado para Joze da 
Roxa Pita. Nesse caso, vislumbramos que a casa possuísse uma estrutura compatível com os outros imóveis elencados entre os mais caros, mas estava alugado a um valor baixo, o que incidiu diretamente no rendimento anual da casa e, consequentemente, na Décima Urbana cobrada.

Do rol dos 22 proprietários que tinham mais de uma casa no arraial em 1817, seis estavam entre os detentores dos imóveis mais valorizados do arraial: Maria Joaquina Gomes, Dona Anna Raimunda de Campos, Manoel Ramalho Ortigas, Capitão Raimundo Fernandes Pereira, Furriel Theotonio Carlos Ramalho e Reverendo Thome de Crasto Carneiro (Figura 23).

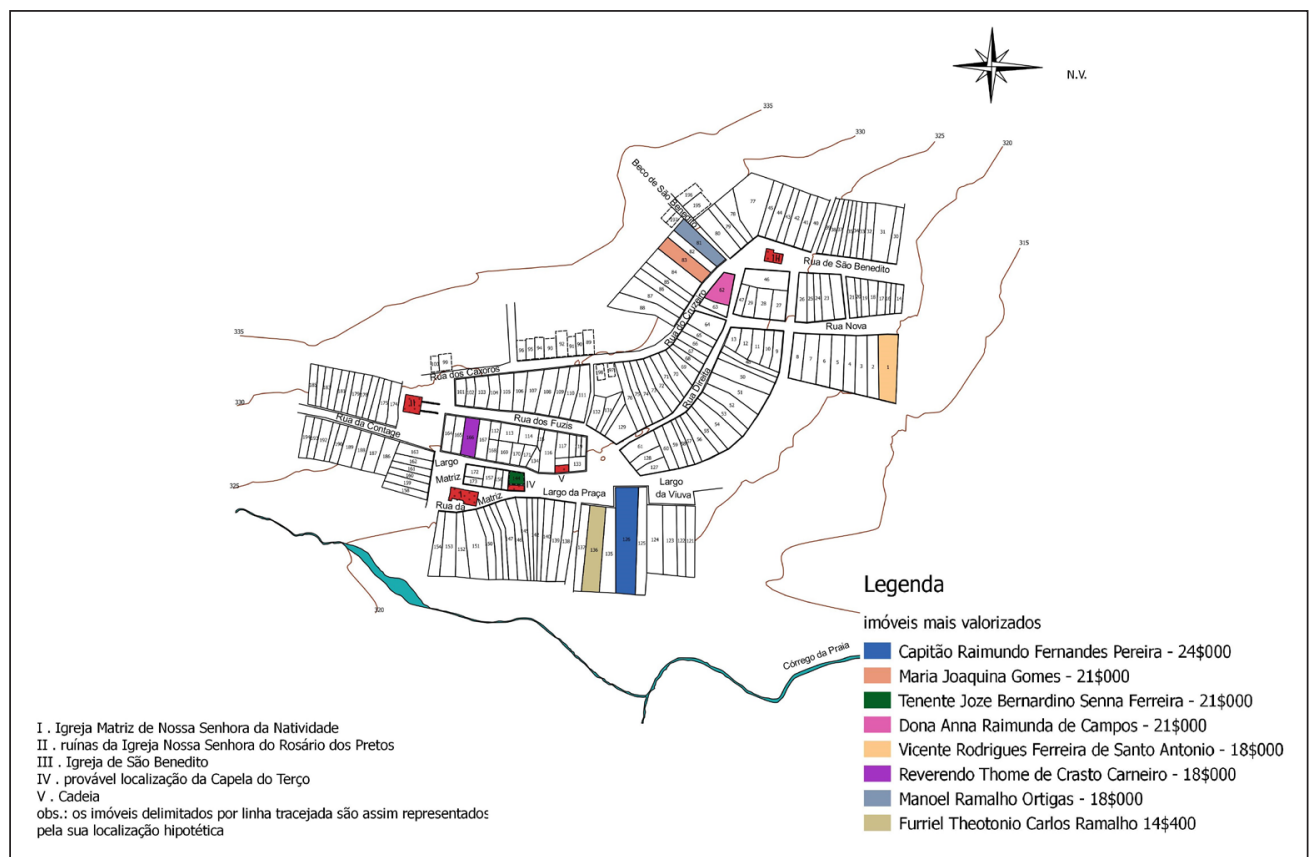

Figura 23 - Mapa de Natividade dos imóveis mais valorizados em 1817 (sem escala). (Mapa hipotético elaborado com base no Lançamento da Décima e Receita de Natividade. Fonte: Muban - Caixa 20, Pasta 1.1.4.)

Um fato curioso diz respeito à situação de Maria Joaquina Gomes, que, embora possuísse dois imóveis no arraial, não morava em nenhum deles. $\bigcirc$ imóvel n 83 na Rua do Cruzeiro, um dos mais valorizados de Natividade, estava alugado para Gonsalo Fernandes Souto, e a casa n 105 na Rua dos Fuzis estava sem morador. Essa situação se repete outras vezes, inclusive entre os proprietários que possuíam apenas uma casa no arraial, como era o exemplo de João Luiz da Silva proprietário da casa n 65 na [Rua Direita] que estava "cem morador". Nesse caso identificamos que João Luiz, "homem branco solteiro", com aproximadamente 35 anos, era "natural e morador neste Arrayal onde vive de Criar Gados". 218 Ao que
218. Muban - "Ofícios e Ocupações - Pessoas com Diversos Cargos III - de 1782 a 1822". Cx. 175, Pasta 4.1.35. Documento de Natividade de 20 de fevereiro de 1818. 
219. Fato curioso, pois uma certa Francisca Araujo era proprietária de um imóvel também na Rua da Matriz, $\mathrm{n}^{\circ}$ 145. Seriam a mesma pessoa?

220. Ainda assim, declarou em seu testamento firmado em 1849 que devia "algumas dívidas por crédito aos quais os meos testamenteiros pagarão sem estrépito de justiça" (Parente, 2005, p. 124). De acordo com a pesquisadora, o testamento do capitão está na Associação Comunitária de Natividade.

221. Muban - "Ofícios e Ocupações - Pessoas com Diversos Cargos III - de 1782 a 1822". Cx. 175, Pasta 4.1.35. Documento de Natividade de 20 de fevereiro de 1818 .

222. O reverendo ficou dispensado de pagar o imposto predial da casa $n^{\circ} 46$ devido ao estado de pobreza da moradora. parece, nesse caso sua casa no arraial devia passar a maior parte do tempo fechada, enquanto João Luiz cuidava do gado em sua fazenda. Maria Joaquina, por exemplo, poderia viver com seus familiares em outra casa no arraial.

Uma característica marcante que diferencia Natividade dos outros núcleos estudados diz respeito às pessoas que "moravam grátis" em imóveis, de terceiros, cujo imposto normalmente era recolhido. Vejamos a situação do Capitão Raimundo Fernandes Pereira, morador da casa n 126 no Largo da Praça, a maior e a mais valorizada do arraial. Ele possuía outros dois imóveis menores, ambos ocupados por pessoas que "moravam grátis": o imóvel n 67 da [Rua Direita], com apenas 2 quartos, varanda e quintal, que estava ocupado por Lucio Thomas; ou a casa $n^{\circ}$ 152, cedida a Francisca de Araujo Lima ${ }^{219}$ na Rua da Matriz, que apresentava dimensões similares, composta por 2 quartos, cozinha e quintal. $\bigcirc$ Capitão, conforme tratamos anteriormente, além de viver de "seo negocio de fazenda seca", também possuía um Engenho. ${ }^{220}$ De acordo com documento de 1818, foi possível verificar que o negociante tinha aproximadamente 53 anos, era "homem pardo solteiro natural e morador neste Arrayal". 221

A categoria "mora grátis" gera o seguinte questionamento: que tipo de sociedade era essa, que possuía tantos agregados? Em 39 imóveis viviam pessoas nessa condição, dentre homens e mulheres, em imóveis de proprietários os mais diversos, padres, homens com patentes militares, donas, irmandades e pessoas comuns. O valor e o tamanho dos imóveis variavam, não existia um padrão. Uma hipótese seria que algumas dessas casas seriam de produtores de gado que tinham suas propriedades rurais como primeira residência, e os imóveis do arraial ficavam fechados ou a cargo de agregados, ou seja, daqueles que "moravam grátis". Outra hipótese diz respeito aos comerciantes que ficavam em trânsito com a "praça da Bahia" e passavam longos períodos fora de Natividade, deixando sua loja a cargo de terceiros. No entanto, no caso do Capitão Raimundo Fernandes, nenhuma dessas hipóteses atenderia, já que ele morava em seu imóvel no Largo da Praça. Vejamos outros casos...

O proprietário que possuía o maior número de casas em Natividade em 1817 era o Reverendo Thome e Crasto Carneiro, detentor de quatro imóveis, todos habitados. O padre possuía imóveis nas proximidades das igrejas Matriz e de São Benedito, sendo três deles cedidos a fiéis. $O$ reverendo habitava numa propriedade de 7 quartos, cozinha e quintal de $n^{\circ} 166$ no Largo da Matriz. Na casa n 167, parede-meia, "morava grátis" Marcelo de Souza Estrella, em um imóvel menor que a residência do reverendo. Não muito longe dali, na casa ${ }^{\circ}$ 146 na Rua da Matriz, "morava grátis" Antonia Luiza de Almeida em outra propriedade do reverendo, assim como Anna Barboza, "viuva mizeravel" que residia na casa da Rua de São Benedito n ${ }^{\circ} 46.222$ 
Assim como o Reverendo Thome e Crasto Carneiro, outros religiosos tinham propriedades em Natividade, normalmente localizadas próximas a alguma das igrejas do arraial. Os párocos Conrado e Lucas Freire figuram na lista de proprietários com mais de um imóvel em Natividade, mas não residiam em nenhum deles. $\bigcirc$ Padre Conrado possuía dois imóveis vizinhos na Rua Nova: na casa de n 09 "morava gratis" Marcelo Alves Maya, e na casa de n 10 estava "cem morador". Os imóveis do Padre Lucas Freire, por sua vez, estavam ambos cedidos para pessoas que "moravam gratis", sendo a casa $n^{\circ} 165$ do Largo da Matriz sob a guarda de Siprianno da Silva e a casa n 112 na Rua dos Fuzis ocupada por Suzana de Almeida. $\bigcirc$ paradeiro do Padre Conrado não foi identificado, mas se o Padre Lucas Freire e o Reverendo Lucas Freire de Andrade forem a mesma pessoa, ele possuía uma casa em Vila Boa em 1817, onde residia. O religioso morava na casa n 301 no Beco da Lapa, próximo à igreja de mesmo nome, cujo rendimento anual era de $36 \$ 000$ réis - valor mais alto que o do imóvel mais valorizado de Natividade naquele ano. Outros religiosos de Natividade elencados na Décima Urbana de 1817 como proprietários não aparecem como moradores, apenas o Reverendo Thome de Crasto Carneiro.

Ao analisar a ocupação dos imóveis de Natividade em 1817, conforme consta na Décima Urbana, verificamos que dos 198 bens, 164 estavam ocupados, 28 imóveis estavam "cem morador", 4 "feixados" e apenas 2 "desmanxados". Dos 164 imóveis ocupados, 113 estariam sob usufruto de seus proprietários, 12 estavam alugados e 39 estavam cedidos para que pessoas morassem "grátis". Em um balanço geral, 83\% dos imóveis estavam ocupados e 17\% desocupados (Figura 24). Comparando com os dados referentes aos arraiais de Pilar e Meia Ponte, Natividade está em uma posição confortável em termos de "estabilidade urbana", uma vez que apresenta baixos níveis de imóveis desocupados.

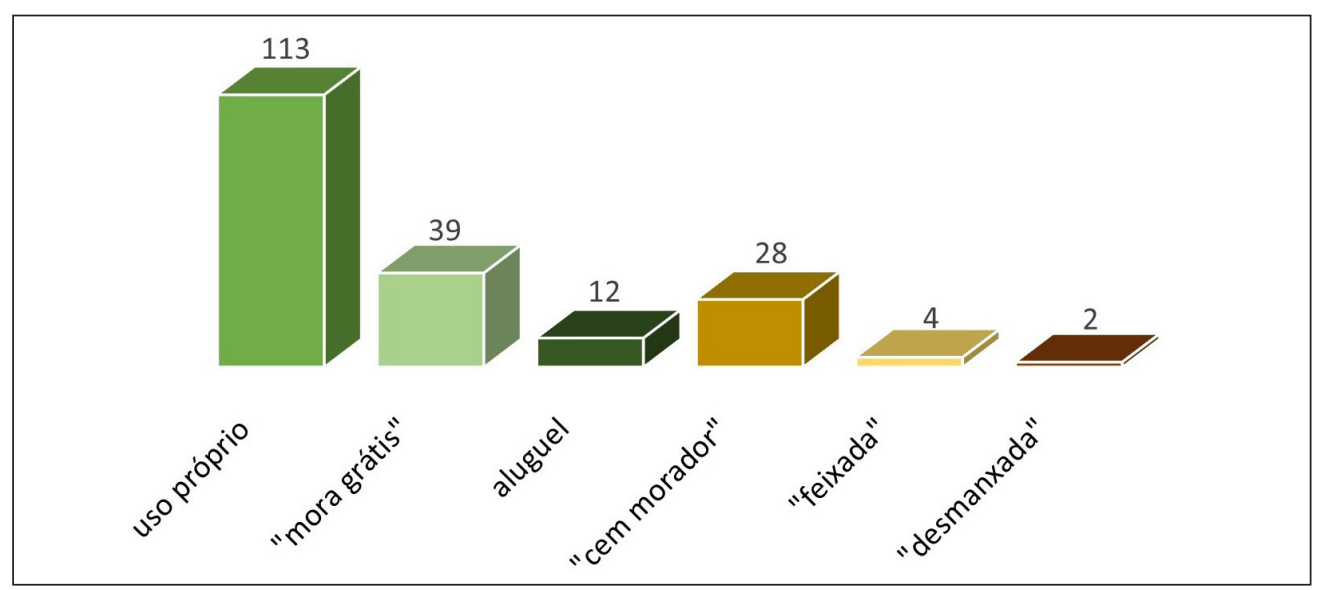

Figura 24 - Ocupação e finalidade dos imóveis. Fonte: Muban - Caixa 20, Pasta 1. 1.4. "Lançamento da Décima e Receita". 
223. Pohl (1976, p. 271).

224. Cf. Livro de registro...

225. Vila Boa, Crixás, Pilar, Traíras, Meia Ponte, Santa Luzia, Santa Cruz e Desemboque.

226. Cavalcante, São Felix, Arraias, Conceição, Natividade e Carmo.
Mesmo que Pohl tenha declarado, em 1819, que os habitantes do arraial estavam "quase reduzidos à indigência, levam uma vida miserável", 223 essa informação não coaduna com a Décima Urbana de Natividade de dois anos antes, que aponta quem seriam esses "miseráveis": proprietários de 5\% do número total dos imóveis e alguns poucos que "moravam grátis" em casas de terceiros, um número considerado baixo se comparado a outros arraiais na mesma época. Embora seja um número pequeno, esses miseráveis existiam e habitavam lado a lado com os proprietários mais abastados do núcleo, por exemplo Nataria Ribeiro da Costa ou Domicianna Maria, miseráveis e proprietárias de imóveis no Largo da Praça, vizinhas do poderoso Capitão Raimundo Fernandes Pereira.

\section{CONSIDERAÇÕES FINAIS}

Com a chegada do século XIX, as localidades iam se adaptando ao sabor das circunstâncias para encontrarem seu lugar na nova dinâmica econômica, marcada pela queda da produtividade do ouro iniciada em meados do Setecentos. O ouro ainda era o produto mais rentável da Capitania na passagem do século, conforme é apresentado no Mapa das Produçoens de Villa Bôa e os sete Julgados da Repartição do Sul na Capitania de Goyaz no anno de 1804 e no Mapa das Produçoens dos seis Julgados da Repartição do Norte na Capitania de Goyaz no anno de 1804, 224 elaborados no governo de D. Francisco de Assis Mascarenhas (1 804-1 809). Do montante geral da Capitania naquele ano, a produção de ouro de lavras equivalia a $59 \%$, a pecuária a $24 \%$ e a agricultura a $17 \%$ do total.

Os dados referentes à exportação de gêneros e de ouro da capitania foram disponibilizados nessas duas tabelas, classificadas como "Mapa das Produções", onde constava a produção dos 13 julgados e de Vila Boa. Considerando o critério adotado por Mascarenhas, que dividiu a capitania em julgados da repartição su|225 e do norte, ${ }^{226}$ o ouro correspondia a $65 \%$ da exportação nos julgados do sul, ao passo que a atividade pecuária abarcava 19\% do montante total e a agrícola, $16 \%$. Nos julgados do norte a situação era diferente, uma vez que a exportação aurífera e a pecuária disputavam a primeira posição, sendo o ouro com $43 \%$ e o gado e seus derivados com $42 \%$; a agricultura seguia com uma exportação parecida aos julgados do sul, figurando como 15\% da produção total daquela região.

As cotações dos produtos, no entanto, apresentavam uma variação de valores referentes aos mesmos gêneros em relação às repartições norte e sul. Se, por um lado, os produtos agrícolas foram mais bem cotados na repartição norte, 
no sul os valores dos produtos pecuários foram muito superiores aos aplicados no norte. Imaginamos que essa diferenciação tenha se dado em função da carência desses produtos nas diferentes regiões: a escassez de gado no sul e a de gêneros agrícolas no norte. Já o ouro, foi cotado da mesma forma de norte a sul, a 1\$200 réis a oitava. Dessa forma, é fácil perceber que a produção e a exportação aurífera no sul ainda era maior e poderia ser justificada pelos novos descobertos de Anicuns, situado a 12 léguas de Vila Boa.

Embora em 1804 o ouro ainda fosse o principal produto da Capitania de Goiás, verificamos uma flutuação da produção entre os julgados das repartições norte e sul, situação semelhante à produção de gado e seus derivados. Logo, não é possível afirmar que a crise tenha afetado a capitania de forma homogênea. Como vimos, são pesos diferentes para as mesmas medidas e isso reflete na heterogeneidade do quadro.

Voltando à análise comparativa da Décima Urbana desses diferentes casos, foi possível rever a ideia de decadência em determinados núcleos do Norte e do Sul, apontando o estado de abandono - ou não - dos imóveis e, consequentemente, dos arraiais. Levando-se em consideração esses quatro núcleos urbanos, podemos afirmar que em algumas situações encontramos um cenário de estagnação ou de um tímido progresso. No entanto, a decadência também se fez notar em alguns casos. Pilar foi um dos núcleos que mais produziu ouro e até chegou a se beneficiar dessa riqueza em uma época em que óperas foram encenadas no teatro, que não existe mais, e edificações de elevado apuro estético eram construídas, como podemos verificar ainda hoje em pelo menos três casas na cidade, remanescentes do século XVIII. Surpreendentemente, essas casas estavam subvalorizadas em relação aos imóveis dos outros sítios estudados. A título de comparação, o imóvel mais valorizado de Vila Boa em 1818 tinha rendimento anual de $86 \$ 400$ réis, ao passo que os imóveis mais valorizados de Pilar em 1816 não passavam de 7 \$200 réis. Reforçando a decadência que assolou Pilar no início do século XIX, encontramos um arraial com decréscimo populacional acentuado e com uma quantidade considerável de imóveis abandonados e, portanto, que não arrecadavam o imposto. Outro ponto que chamou atenção foi o número de proprietários elencados na Décima Urbana como pobres, miseráveis, doentes, indigentes e mendigos, dentre outros, o que equivalia a $16 \%$ do total de proprietários de imóveis cadastrados em 1816.

Meia Ponte é um caso em que a análise sobre a decadência deve ser mais aprofundada, de modo a contemplar fatores variados. Localizada no entroncamento de importantes caminhos coloniais, Meia Ponte tinha na atividade comercial outro forte ponto de sua economia, para além da extração aurífera. Em 1824, contudo, Cunha Mattos 227 alerta para a ruína das pontes dos rios Urú e Almas, o que condicionaria a mudança de rota dos comboios de Cuiabá e negociantes da 
cidade de Goiás, que antes passavam pelo arraial. $\bigcirc$ sítio urbano era o segundo maior da Capitania de Goiás, ficando atrás apenas de Vila Boa, totalizando 308 fogos. Desses, apenas 131 estavam ocupados em 1819, o que equivale que menos da metade das casas no núcleo urbano estava em uso; o restante os imóveis estavam desabitados (12\%) ou arruinados (46\%). Dados como esses nos levam a considerar a ruína do arraial, no entanto outras condicionantes estavam em jogo. Ao analisar a bibliografia que relata um processo imersivo de ruralização de Meia Ponte, confirmada por sua produção rural, constatamos que houve um êxodo urbano, o que desencadeou o esvaziamento do arraial. Alguns pesquisadores associam o processo de ruralização à decadência, mas recomendamos uma análise mais aprofundada dos Dízimos coletados em Meia Ponte antes de fazer essa afirmação, assim como dos cadernos de cobranças das Contagens e Registros, situados nas estradas que desembocavam no arraial.

Desde o século XVIII, Natividade convivia mais com a produção pecuária, concomitante com a extração de ouro. Talvez por esse perfil, a Décima Urbana de 1817 não tenha demonstrado dados preocupantes como os vistos anteriormente. Mesmo não tendo atingido o status de vila no período colonial, Natividade foi escolhida como moradia do Ouvidor da Comarca Norte por alguns anos. Em um momento em que os arraiais ligados exclusivamente à atividade aurífera sofreram com a evasão de pessoas para outros lugares no início do século XIX, Natividade apresentou um discreto aumento no número de fogos. Nesse arraial não contabilizamos índices de decadência durante o período estudado, ainda mais se considerarmos a alta taxa de ocupação dos imóveis que, por sua vez, se apresentaram mais valorizados que aqueles encontrados em Pilar ou em Meia Ponte.

Por fim, Vila Boa gozava de certa estabilidade no início do Oitocentos, o que se devia ao fato de ser a sede administrativa da Capitania de Goiás. Lá estavam os imóveis mais valorizados e todo o aparato administrativo, além de espaços de convívio como o Passeio Púbico, próximo ao Chafariz da Boa Morte. O núcleo urbano era muito maior que os demais, somando o total de 725 imóveis em 1818, visto que apenas dez deles estavam arruinados, segundo dados fornecidos pela Décima Urbana.

O pico da extração de ouro ocorrev em meados do século XVIII, no entanto, alguns arraiais no início do Oitocentos já sentiam o impacto da escassez do metal, como Pilar ou Ouro Fino. É importante lembrar que outros circuitos econômicos também movimentavam a capitania, como o comércio, a criação de gado e a agricultura, e tiveram peso decisivo quando a queda da produção aurífera se acentuou, principalmente a partir do início do século XIX. Por esse motivo, aqueles arraiais que desde o início conseguiram manter certo equilíbrio em relação à 
extração de ouro e à manutenção de outras atividades econômicas permaneceram estáveis ou apresentaram um quadro com leve crescimento.

Diante desse cenário tão diversificado, seria um equívoco generalizar e afirmar que a decadência atingiu de forma homogênea toda a Capitania de Goiás. Pela complexidade do tema, sabemos que a análise aqui empreendida foi pontual, por abarcar principalmente aspectos do intraurbano em um universo de apenas quatro cidades. Deixamos aqui a provocação e o incentivo para futuros pesquisadores darem continuidade a este estudo, não se esquecendo de que é preciso considerar uma análise que ultrapasse os fatores econômicos, de modo a abarcar também outras camadas que animam a vida social. 


\section{REFERÊNCIAS}

FONTES MANUSCRITAS

LANÇAMENTO da Décima e Receita (Meia Ponte, Pilar, Natividade, Villa Boa) - Caixas 18 - 23. Arquivo do Museu das Bandeiras - Muban (Goiás).

LANÇAMENTO da Decima das Cazas. Villa de Meiaponte 1837. Municípios - Pirenópolis Caixa 1 de 1812 - 1849. Arquivo Histórico do Estado de Goiás (Goiânia).

LANÇAMENTO da Decima Urbana. Pilar 1838, 1839. Municípios - Pilar de Goiás - Caixa 1 de 1834 - 1850. Arquivo Histórico do Estado de Goiás (Goiânia).

LIVRO das Cargas do Concelho deste Julgado [Pilar]. Arquivo do Museu das Bandeiras - Muban (Goiás).

LIVRO de Notas n ${ }^{\circ}$ 55. "Juízo Geral - Juiz de Fora Lucio Soares Teixeira de Govea - 1818-1820" - folhas 2, 2V e 3. Arquivo do Museu das Bandeiras - Muban (Goiás).

LIVRO de registro da correspondência oficial de d. Francisco de Assis Mascarenhas, capitão geral da capitania de Goiás, com a Corte, relativo ao governo da dita capitania. Manuscritos - Cod. 09.04.002 e Cod. 09.04.003. Fundação Biblioteca Nacional (Rio de Janeiro).

PROCURAÇÃO bastante que fazem e assignão o Capitão Jozé Joaquim Pulquerio dos Santos e sua mulher Dona Maria Angelica, e Dona Anna Clara de Jezus aos nella nomeados como abaixo se declara. Livro de Notas $\mathrm{n}^{\circ} 68$ "Juiz Municipal - Joaquim Xavier dos Guimaraens Frances 1835-1837 (folhas 121V, 122 e 122V). Arquivo do Museu das Bandeiras - Muban (Goiás).

PROVISÃO (cópia) do rei D. João V, ao governador e capitão-general de São Paulo, Conde de Sarzedas, ordenando-lhe que passe às Minas de Goiás e nelas determine o lugar mais adequado para a criação de uma vila. Lisboa, 11 de fevereiro de 1736. AUH_ACL_CU_008, Cx. 1, D. 26 - Goiás.

RELAÇÃO dos Habitantes aSituados no termo da Freguesia d'Nossa Senhora do Rozario, Minas d'Meia Ponte, Comarca de Villa boa d'Goyas (1818). Documentação Avulsa I - Caixa 9 - Pacote 2. Arquivo Histórico do Estado de Goiás (Goiânia). 


\section{FONTES CARTOGRÁFICAS}

PLANTA de Vila Boa Capital da Capitania Geral de Goyas levantada no ano de 1782. Arquivo do Museu das Bandeiras - Muban (Goiás).

MAPPA dos sertões que se comprehendem de Mar a Mar entre as capitanias de S. Paulo, Goyazes, Cuyabá, Mato-Grosso e Pará. Fundação Biblioteca Nacional - Brasil. Manuscritos Cod. 049, 05, 008, n. 02.

FONTES IMPRESSAS

BERTRAN, Paulo (org.). Notícia Geral da Capitania de Goiás em 1783. Goiânia, Instituto Casa Brasil de Cultura, 2010.

BERTRAN, Paulo (org.). Notícia Geral da Capitania de Goiás em 1783. Goiânia, Ed. UCG-UFG e SOLO Editores, 1997.

CARTA DE LEI de 17 de setembro de 1818 - Erige em Cidade Villa Boa com a denominação Cidade de Goyaz.

CASTELNAU, Francis. Expedição às Regiões Centrais da América do Sul. Belo Horizonte: Itatiaia, 2000.

CRULS, L. Commissão exploradora do planalto central do Brasil, H.Lombarts \& C., Impressores do Observatório, Rio de Janeiro, 1894.

CUNHA MATTOS, Raimundo José da. Chorographia histórica da província de Goyaz. Goiânia: Convênio Sudeco/Governo de Goiás, 1979.

CUNHA MATTOS, Raimundo José da. Itinerário do Rio de Janeiro ao Pará e Maranhão, pelas províncias de Minas Gerais e Goiás, seguido de uma descrição corográfica de Goiás, e dos roteiros desta província às do Mato Grosso e S. Paulo. Belo Horizonte: Instituto Cultural Almicar Martins, 2004.

D’ALINCOURT, Luiz. Memória sobre a viagem do porto de Santos à cidade de Cuiabá. Belo Horizonte: Itatiaia; São Paulo: USP, 1975.

ESCHWEGE, W. L. von. Pluto Brasiliensis. Belo Horizonte: Itatiaia; São Paulo: USP, 1979.

GARDNER, George. Viagem ao interior do Brasil. Belo Horizonte: Itatiaia; São Paulo: USP, 1975. 
PINHEIRO; COELHO (orgs.). Diário de viagem do Barão de Mossâmedes: 1771/1773. Goiânia: Trilhas Urbanas, 2006.

POHL, Johann Emanuel. Viagem ao interior do Brasil. Belo Horizonte: Itatiaia; São Paulo: USP, 1976.

SAINT-HILAIRE, Auguste de. Viagem à província de Goiás. Belo Horizonte: Itatiaia; São Paulo: USP, 1975.

SOUSA, Luiz Antonio da Silva. O Descobrimento, Governo, População e Cousas Mais Notaveis da Capitania de Goyaz. In Revista do Instituto Historico Geographico Brazileiro. V1. XII. Rio de Janeiro: Thypographia de João Ignacio da Silva, 1874.

SPIX, Johann Baptist von; MARTIUS, Carl Friedrich Philipp von. Viagem pelo Brasil: 1817-1820. Vol. 2. Belo Horizonte: Ed. Itatiaia; São Paulo: Edusp, 1981.

LIVROS, ARTIGOS E TESES

ABREU, Mauricio Almeida de. Geografia Histórica do Rio De Janeiro (1502-1700). Rio de Janeiro: Andrea Jakobsson Estúdio \& Prefeitura do Município do Rio de Janeiro, 2010, 2v.

ANDRADE, Amélia. Horizontes Urbanos Medievais. Lisboa: Livros Horizonte, 2003.

ARRUDA, José Jobson de Andrade. O elo perdido: a economia brasileira entre 1780 e 1830 . in Resgate. Campinas, v. 6, n. 7, 1997, p. 97-100.

AZEVEDO, Francisco Ferreira dos Santos. Annuario Historico, geographico e descriptivo do Estado de Goyaz. Brasília: SPHAN, 1987.

BERTRAN, Paulo. História da Terra de do Homem no Planalto Central: eco-bistória do Distrito Federal. Brasília: Editora Universidade de Brasília, 2011.

BERTRAN, Paulo; GALVÃO JUNIOR, José Leme; et al. Formação Urbana de Pirenópolis. In IPHAN. Caderno de Documentos - Estudo de Tombamento. Rio de Janeiro: Iphan, 1995.

BORREgO, Maria Aparecida de Menezes. A teia mercantil: negócios e poderes em São Paulo colonial (1711 - 1765). São Paulo: Alameda, 2010.

BORSOI, Diogo Fonseca. Nos traços do cotidiano: Cunba entre as vilas de serra acima es portos da marinha (1776 - 1817). 2013. Dissertação (Mestrado) - Faculdade de Arquitetura e Urbanismo, Universidade de São Paulo, São Paulo, 2013. 
BUENO, Beatriz Piccolotto Siqueira. Tecido Urbano e Mercado Imobiliário em São Paulo: metodologia de estudo com base na Décima Urbana de 1809. In Anais do Museu Paulista. [online]. 2005, vol.13. Disponível em: <https://bit.ly/35jFlzr>. Acesso em: 09 jun. 2015.

BUENO, Beatriz Piccolotto Siqueira. Arqueologia da paisagem urbana: lógicas, ritmos e atores na construção do centro histórico de São Paulo (1809-1942). Rev. Inst. Estud. Bras., São Paulo, n. 64, p. 99-130, Aug. 2016. Disponível em: <https://bit.ly/3bh617B>. Acesso em: 24 nov. 2016.

BRAUDEL, Fernand. Civilização material, economia e capitalismo nos séculos XV-XVIII. (As estruturas do cotidiano: o possível e o impossível). Vol. I. São Paulo: Martins Fontes, 1995.

BURKE, Peter. Hibrismo cultural. São Leopoldo: Editora Unisinos, 2003.

CAVALCANTI, Nireu. O Rio de Janeiro Setecentista: a vida e a construção da cidade da invasão francesa até a chegada da Corte. Rio de Janeiro: Jorge Zahar Editor, 2004.

CHAUL, Nasr Fayad. Caminhos de Goiás - da construção da decadência aos limites da modernidade. Goiânia: Ed. da UFG, 2010.

COELHO, Gustavo Neiva. O diário de viagem de José de Almeida de Vasconcellos Soveral e Carvalho governador da Capitania de Goyaz. In COELHO; PINHEIRO (orgs.). Diário de viagem do Barão de Mossâmedes: 1771/1773. Goiânia: Trilhas Urbanas, 2006.

CORAliNA, Cora. Poemas dos Becos de Goiás e Estórias mais. São Paulo: Global Editora, 1987.

COSTA, Lena Castelo Branco Ferreira da. Arraial e Coronel. Dois Estudos de História Social. São Paulo: Cultrix, 1978.

DPHAN. Processo $n^{\circ} 478-T-52$, Conjunto Arquitetônico e Urbanístico - Pilar. Rio de Janeiro: Iphan, 1952.

DUBUGRAS, Elvin Mackay. Notas sobre a arquitetura do século XVIII em Pilar de Goiás. Brasília: UNB, 1965.

FERREZ, Gilberto. O Brasil do Primeiro Reinado visto pelo botânico William John Burchell 1825/1829. Rio de Janeiro: Fundação Nacional Moreira Salles e Fundação Nacional próMemória, 1981.

FONSECA, Cláudia Damasceno. As vilas e os territórios: processos de formação e evolução da rede urbana na capitania de Minas Gerais. In CNCDP. Actas do Colóquio Internacional A Cidade como Civilização: Universo Urbanístico Português - 1415 - 1822. Lisboa: CNCDP, 2001. 
FUNES, Eurípedes Antônio. Goiás 1800 - 1850: um período de transição da mineração à agropecuária. Goiânia: Editora da UFG, 1986.

GARCIA, João Carlos (coord.). A Mais Dilatada Vista do Mundo. Inventário da Colecção Cartográfica da Casa da Ínsua. Lisboa: C.N.C.D.P., 2002.

GAUTHIEZ, Bernard; ZELLER, Olivier. Lyons, the Spatial Analysis of a City in the 17th and 18th centuries. Locating and Crossing data in a GIS Built from written sources. In Mapping Spatial Relations, their perceptions and dynamics. The city today and in the past, Springer International Publishing Switzerland, p.97-118, 2014, Lecture Notes in Geoinformation and Cartography, 2014.

IPHAN. Processo $n^{\circ} 345-T-42$, Processo de Tombamento de Goiás. Rio de Janeiro: Iphan, $1942,4 \mathrm{v}$.

IPHAN. Processo $n^{\circ} 1.117-T-84$, Conjunto: Arquitetônico, Paisagístico e Urbanístico da Cidade de Natividade - Goiás. Brasília: Iphan, 1984.

IPHAN. Processo $n^{\circ} 1.181-T-85$, Processo de Tombamento do Centro Histórico de Pirenópolis. Brasília: Iphan, 1985. $4 \mathrm{v}$.

JAYME, Jarbas; JAYME, José Sisenando. Pirenópolis - Casa dos Homens. Goiânia: Ed. da UCG, 2003. V1. 2.

KATO, Allan Tomas Tadashi. Retrato urbano: estudo da distribuição socioespacial dos moradores de Paranaguá, Antonina e Curitiba no início do século XIX. 2011. Dissertação (Mestrado em História) - Departamento de História, Universidade Federal do Paraná, Curitiba, 2011.

LACERDA, Regina. Vila Boa - história e folclore. Goiânia: Oriente, 1977.

LE GOFF, Jacques. O apogeu da cidade medieval. São Paulo: Martins Fontes, 1992.

LEPETIT, Bernard. Por uma nova história urbana: seleção de textos, revisão crítica e apresentação Heliana Angotti Salgueiro. São Paulo: EDUSP, 2001.

LEMES, Fernando Lobo. Por uma releitura da história. A historiografia de Goiás e o paradigma da decadência. In LEMES (coord.) Para além das Gerais: dinâmicas dos povos e instituições na América Portuguesa - Babia, Goiás e Mato Grosso. Goiânia: Editora da PUC Goiás, 2015.

LIMA, Elder Rocha. Guia afetivo da Cidade de Goiás. Brasília: Iphan, 2008.

MARQUES, Octo. Causos e lendas de Vila Boa. Goiânia: Gráfica O Popular, 1977. 
MARX, Murillo. Cidade no Brasil. Terra de quem? São Paulo: Edusp/Nobel, 1991.

MONTEIRO, Ofélia Sócrates do Nascimento. Reminiscências - Goiás de antanho. Goiânia: Oriente, 1974.

MOURA, Nádia Mendes de. Fazenda Babilônia. 2004. Levantamento Cadastral (Vl. 1), Diagnóstico (Vl. 2) e Projeto de Restauração (Vl. 3). Trabalho Final (Especialização) - Cecre (Curso de Especialização em Conservação e Restauração de Monumentos e Conjuntos Históricos). Programa de Pós-Graduação em Arquitetura e Urbanismo, Universidade Federal da Bahia, Salvador, 2004.

MOURA, Nádia Mendes de. A Igreja e a constituição dos núcleos mineradores goianos do Setecentos. In Revista Caminhos - Revista de Ciências da Religião., Goiânia, v. 17, p. 635-648, Set. 2019. Disponível em: <http://bit.ly/3f9GdMO>. Acesso em: 23 mar. 2020.

NITA, (Mariana Augusta Fleury Curado). Rua do Carmo. Goiânia: Editora Líder, 1981.

OLIVEIRA, Adriana Mara Vaz de. Fazendas goianas: a casa como universo de fronteira. Goiânia: Editora UFG, 2010.

PALACÍN, Luiz. Goiás 1722/1822 - Estrutura e Conjuntura numa Capitania de Minas. Goiânia: Editora Gráfica Oriente, 1972.

PALACÍN, Luiz; GARCIA, Ledonias Franco; AMADO, Janaína. História de Goiás em Documentos. Goiânia: Editora da UFG, 1995.

PARENTE, Temis Gomes. O Avesso do Silêncio: vivências cotidianas das mulberes do século XIX. Goiânia: Editora da UFG, 2005.

REIS, Nestor Goulart. Imagens de vila e cidades do Brasil Colonial. São Paulo: FUPAM, 2000. CD ROM.

REIS, Nestor Goulart. Evolução Urbana do Brasil 1500/1700. São Paulo: Pini Editora, 2001.

REIS, Nestor Goulart. As Minas de Ouro e a formação das Capitanias do Sul. São Paulo: Via das Artes, 2013.

RODRIGUES, J. Lopes. Natividade - Fragmentos do Passado. Natividade: Edição do autor, 1978.

SALLES, Gilka V. Ferreira. Economia e escravidão na Capitania de Goiás. Goiânia: CEGRAF/ UFG, 1992. 
SANTOS, Milton. A Natureza do Espaço. São Paulo: Edusp, 2014.

SOUZA, Laura de Mello e. Desclassificados do Ouro: a pobreza mineira no século XVIII. Rio de Janeiro: Edições Graal, 2004.

SOUZA. Marcos André Torres de. Spaces of Difference: an Archaeology of Slavery and Slave Life in a 19th Century Brazilian Plantation. Tese (Doutorado). Department of Anthropology, Syracuse University, United States, 2010.

TELES, José Mendonça (coord.). Vida e obra de Silva e Souza. Goiânia: Editora da UFG, 1998.

VASCONCELOS, Pedro de Almeida. Os Agentes Modeladores das Cidades Brasileiras no Período Colonial. In Explorações Geográficas. Rio de Janeiro: Bertrand Brasil, 1997.

VAZ, Maria Diva Araujo Coelho. Natividade. Brasília: Fundação Nacional Pró-Memória, 1985.

ZANETTINI Arqueologia (org.). Trabalbo e Memória: reflexões sobre arqueologia e patrimônio cultural em Pilar de Goiás. São Paulo: Zanettini Arqueologia, 2017.

Artigo apresentado em: 27/7/2020. Aprovado em: 8/9/2020.

\section{(cc) BY}

